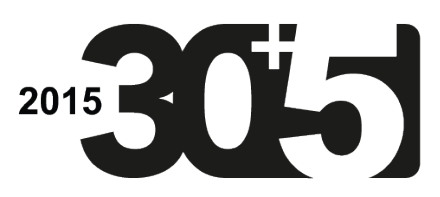

\title{
FERRAMENTA DE APOIO AO DESENVOLVIMENTO DE PROJETOS NO ÂMBITO DA SUSTENTABILIDADE NA CONSTRUÇÃO
}

Dissertação de Mestrado

Daniel Costa Reis

Orientador: Prof. Dr. Márcio Minto Fabrício 


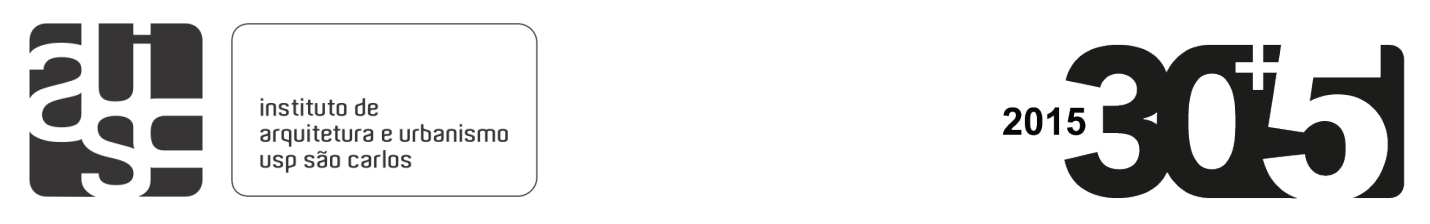

\section{FERRAMENTA DE APOIO AO DESENVOLVIMENTO DE PROJETOS NO ÂMBITO DA SUSTENTABILIDADE NA CONSTRUÇÃO}

Dissertação de Mestrado apresentada ao Instituto de Arquitetura e Urbanismo da Universidade de São Paulo para obtenção do título de Mestre em Arquitetura e Urbanismo.

Área de Concentração:

Arquitetura, Urbanismo e Tecnologia

Autor: Daniel Reis

Orientador: Prof. Dr. Márcio Minto Fabrício 
AUTORIZO A REPRODUÇÃO TOTAL OU PARCIAL DESTE TRABALHO, POR QUALQUER MEIO ĊONVENCIONAL OU ELETRÔNICO, PARA FINS DE ESTUDO E PESQUISA, DESDE QUE CITADA A FONTE.

Reis, Daniel Costa
Ferramenta de apoio ao desenvolvimento de projetos
RR347f âmbito da sustentabilidade na construço / Daniel
Costa Reis; orientador Márcio Minto Fabricio. São
Carlos, 2015.
Dissertação (Mestrado) - Programa de Pós-Graduação
em Arquitetura e Urbanismo e Área de Concentração em
Arquitetura, Urbanismo e Tecnologia -- Instituto de
Arquitetura e Urbanismo da Universidade de São Paulo,
2015.
1. Construção sustentável. 2. Gestão de projetos.
3. Processo de concepção integrado. 4. Sistemas de
certificação e avaliação da sustentabilidade em
edifícios. 5. LEED. I. Título.


FOLHA DE JULGAMENTO

Candidato: Engenheiro Civil Daniel Costa Reis

Título da dissertação: "Ferramenta de apoio ao desenvolvimento de projetos no âmbito da sustentabilidade na construção".

Data da defesa: 14/07/2015

Comissão Julgadora:

Resultado:

Prof. Dr. João Adriano Rossignolo

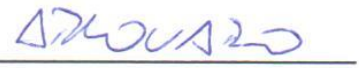

(Faculdade de Zootecnia e Engenharia de Alimentos - USP)

Profa. Dra. Mônica Santos Salgado

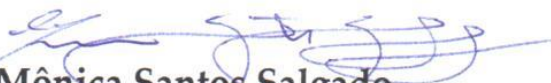

(Facufdade de Arquitetura e Urbanismo - UFRJ)
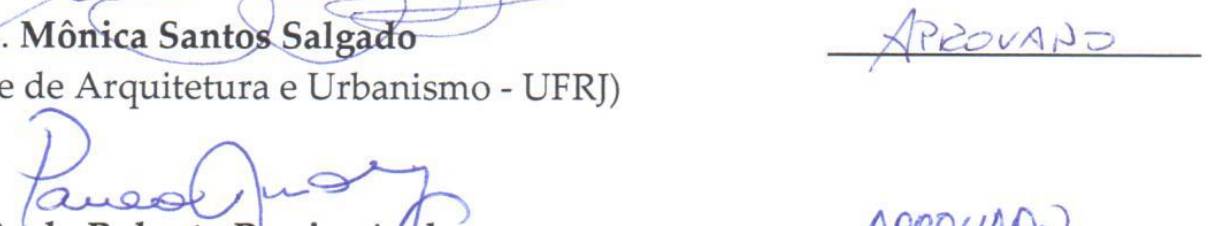

Prof. Dr. Paulo Roberto Pereira Andery

(Departamento de Engenharia de Materiais e Construção Civil - UFMG)

Coordenador e Presidente da Comissão de Pós-Graduação do Programa de PósGraduação em Arquitetura e Urbanismo: Prof. Dr. Márcio Minto Fabrício 



\section{AGRADECIMENTOS}

Ao finalizar a presente dissertação pretendo demonstrar a minha gratidão a todas as pessoas que contribuíram, direta ou indiretamente, para a sua concretização.

Agradeço penhoradamente aos valiosos contributos do meu orientador, o Professor Doutor Márcio Minto Fabrício, não só em termos pessoais mas também académicos sem o qual não teria sido possível a realização deste trabalho.

Agradeço ao Eng ${ }^{\circ}$. José Manuel Martins Soares de Sousa, Professor no Instituto Superior de Engenharia do Porto, pela disponibilidade e sugestões no que diz respeito ao desenvolvimento da ferramenta apresentada neste trabalho.

Um agradecimento especial ao Professor Doutor Alberto Manuel Carneiro Sereno, que muito me ajudou durante os primeiros passos aqui no Brasil e ao longo das minhas atividades académicas.

Agradeço aos meus pais pelo apoio que me facultaram durante a minha estadia do Brasil.

Agradeço aos meus amigos do Instituto de Arquitetura e Urbanismo e do vôlei mais próximos pelo auxílio e amizade que sempre transmitiram.

O último agradecimento vai para a Andreia Martins pelo incentivo, companheirismo e ajuda ao longo das minhas atividades desenvolvidas no Instituto de Arquitetura e Urbanismo da Universidade de São Paulo.

Por fim, gostaria de demonstrar o meu reconhecimento à CAPES (Coordenação de Aperfeiçoamento de Pessoal de Nível Superior) pela bolsa de pesquisa.

"We can not solve problems by using the same kind of thinking we used when we created them"

Albert Einstein 

Reis, D.C. Ferramenta de apoio ao desenvolvimento de projetos no âmbito da sustentabilidade na construção. 2015. Dissertação (Mestrado em Arquitetura e Urbanismo) - Instituto de Arquitetura e Urbanismo da Universidade de São Paulo, São Carlos.

\section{RESUMO}

A indústria da construção, nomeadamente no setor da edificação, baseia-se essencialmente em métodos de construção tradicional. Esta indústria é caracterizada pela elevada quantidade de recursos que consome, pela quantidade de resíduos que produz, a sua implicação na economia dos países e à sua inter-relação com a sociedade. Esta realidade é de todo incompatível com os desígnios do desenvolvimento sustentável, nos quais se procura a correlação harmoniosa entre as vertentes ambiental, social e econômica.

O desafio da sustentabilidade colocado à atividade da construção tem motivado abordagens distintas, não só por parte das várias especialidades da engenharia, como também da arquitetura. Neste sentido, o presente trabalho propôs-se a desenvolver uma Ferramenta que, de uma forma coordenada e integrada permita orientar o desenvolvimento do projeto para soluções sustentáveis ao longo das várias fases do ciclo de evolução de um projeto. Foi desenvolvida recorrendo a uma pesquisa bibliográfica sobre o tema da gestão de projetos e sobre o sistema de certificação de sustentabilidade Leadership in Energy and Environmental Design (LEED). Para além disto, foram ainda incorporados alguns requisitos normativos, obtidos por meio de normas brasileiras ABNT, normas Americanas e normas Europeias.

Pensa-se que da adequada aplicação desta ferramenta, os objetivos definidos pelo promotor da obra em termos de sustentabilidade, poderão ser mais facilmente atingidos pela equipa de projetista através da consideração antecipada de medidas e soluções de sustentabilidade nas diferentes fases de desenvolvimento do projeto permitindo assim, um melhor desempenho do edifício ao nível da construção sustentável.

\section{PALAVRAS-CHAVE}

Construção sustentável; Gestão de projetos; Processo de concepção integrado; Sistemas de certificação e avaliação da sustentabilidade em edifícios; LEED 

Reis, D.C. Support tool for design process in the context of sustainable construction. 2015. Dissertation (Master' degree in Architecture and Urbanism) Instituto de Arquitetura e Urbanismo da Universidade de São Paulo, São Carlos.

\section{ABSTRACT}

The construction industry, particularly in the building sector, is based mainly on traditional construction methods. This industry is characterized by excessive consumption of resources, the amount of waste it produces, its implication in the economy of countries and their relationship with society. This reality is entirely incompatible with the aims of sustainable development, which seeks a harmonious relationship between the environmental, social and economic aspects.

The sustainability challenge faced by the construction activity has motivated different approaches, not only by the various engineering specialties, but also by the architecture. In this sense, this paper aimed to develop a model in a coordinated and integrated manner to guide the development of the project to sustainable solutions throughout the various stages of the project life cycle. It was developed using a literature review about the topic of project management and sustainability assessment tool Leadership in Energy and Environmental Design (LEED). Furthermore, and to improve the effectiveness of the Model, it was been incorporated some standardisation requirements, obtained by Brazilian standards ABNT, American standards and European standards.

Through proper application of this tool, the goals set by Owner of the work, in terms of sustainability, can be more easily achieved by the project design team through timely consideration of measures and sustainability solutions at different stages of project development. Allowing a better performance of the building in terms of the sustainable construction.

\section{KEYWORDS}

Sustainable construction; Design management; Integrated Design Process; Sustainable assessment tools; LEED 



\section{SUMÁRIO}

CAPÍTULO 1 - FUNDAMENTAÇÃO E OBJETIVOS $\ldots \ldots \ldots \ldots \ldots \ldots \ldots \ldots . . \ldots 1$

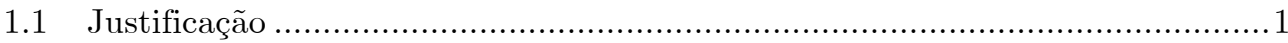

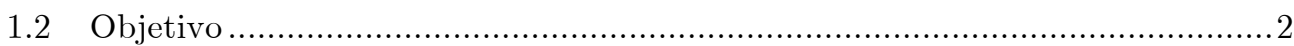

1.3 Estrutura da Dissertação .......................................................

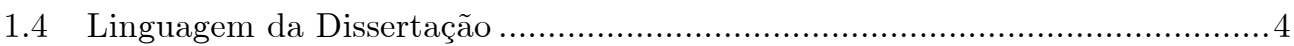

CAPITULO 2 - BASES PARA A SUSTENTABILIDADE.............. 5

2.1 Situação Global.......................................................................... 5

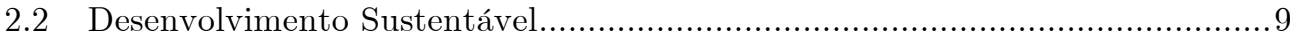

2.3 Construção Sustentável ................................................................ 14

2.3.1 Conceitos e Evolução ........................................................ 16

2.4 Impactos Ambientais Associados ao Ciclo de Vida dos Edifícios................... 22

2.5 Principais Barreiras à Implementação da Sustentabilidade na Industria da

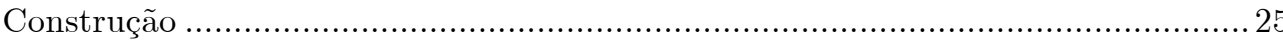

CAPÍtUlO 3 - METOdologias DE APOIO À CONCEPÇÃO E CERTIFICAÇÃO DA SUSTENTABILIDADE DE EDIFÍCIOS .......... 31

3.1 Enquadramento ......................................................................... 31

3.2 Principais Condicionantes na Avaliação da Sustentabilidade nos Edifícios ... 37

3.3 Análise de Ciclo de Vida............................................................... 39

3.3.1 ACV na Construção Civil ......................................................... 40

3.3.2 Métodos Disponíveis na Análise do ACV ......................................... 41

3.3.3 ACV e os Três Pilares do Desenvolvimento Sustentável ......................4 46

3.4 Sistemas de Certificação da Sustentabilidade de Edifícios...........................47

3.4.1 Tipos de Ponderação e Especificidades dos Sistemas .......................... 50

3.4.2 Sistema de Certificação de Sustentabilidade AQUA ............................52

3.4.3 Sistema de Certificação da Sustentabilidade LEED ...........................55

CAPÍTULO 4 - GESTÃo DE PROJETOS..............................61 61

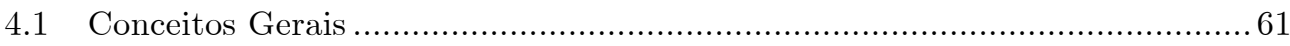


4.1.1 Definição de Projeto

4.1.2 Gestão de Projetos .................................................................. 62

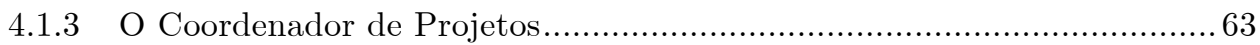

4.2 Processo de Desenvolvimento de um Edifício/Empreendimento................... 65

4.3 A Importância do Projeto para a Construção Sustentável ............................72

4.3.1 Influências das Decisões no Ciclo de Vida de um Edifício ..................... 76

4.4 Algumas Considerações de Sustentabilidade nas Várias Fases de Projeto..... 80

4.4.1 Programa de Necessidades e Estudo de Viabilidade ............................ 81

4.4.2 Estudo Preliminar ......................................................... 82

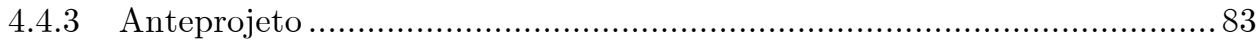

4.4.4 Projeto Legal................................................................. 85

4.4.5 Projeto de Execução.............................................................. 86

CAPÍTULO 5 - MÉTODO ADOPTADO NO DESENVOLVIMENTO DA

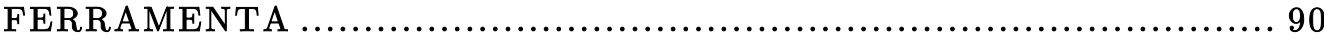

5.1 Seleção da Metodologia de Avaliação de Sustentabilidade Adoptada na

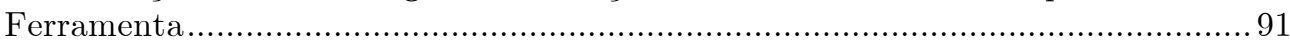

5.2 Seleção do Tipo de Edifícios Adoptado na Ferramenta ............................. 93

5.3 Seleção dos Documentos Normativos.................................................... 93

5.4 Seleção do Software Adoptado na Ferramenta ................................... 94

CAPITULO 6 - FERRAMENTA PROPOSTA ......................... 95

6.1 Organização da Ferramenta........................................................... 97

6.1.1 Fase 1 - Desenvolvimento da Estrutura de Gestão ............................. 99

6.1.2 Fase 2 - Desenvolvimento dos Processos ...................................... 106

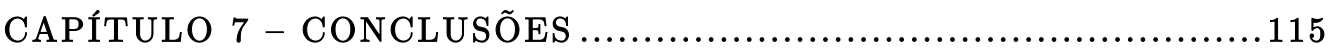

7.1 Avaliação da Realização dos Objetivos Propostos ................................... 115

7.2 Contribuições para a Comunidade Científica e para os Projetistas ............. 116

7.3 Trabalhos Futuros .................................................................. 117

REFERENCIAS BIBLIOGRÁFICAS .................................... 118

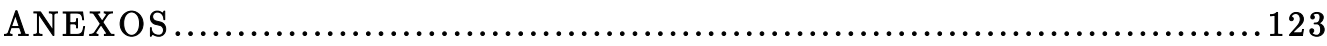


ANEXO A. CRÉDITOS ASSOCIADOS AO LEED-NC...

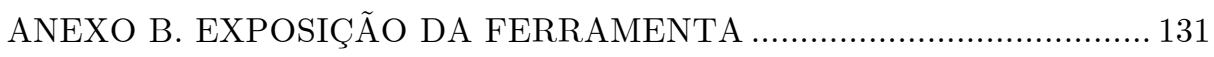




\section{ÍNDICE DE FIGURAS}

Figura 2.1: Evolução do CO2 na atmosfera ...............................................................

Figura 2.2: Evolução da população mundial no último milénio e evolução espectável

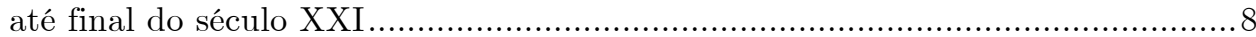

Figura 2.3: As três vertentes do desenvolvimento sustentável ...............................11

Figura 2.4: Consumo equivalente da população mundial ....................................... 12

Figura 2.5: Índice de desenvolvimento humano e pegada ecológica .........................13

Figura 2.6: Consumos energéticos por atividade ………..................................... 15

Figura 2.8: Comparação do consumo energético residencial do Brasil em outros

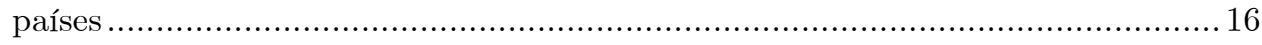

Figura 2.9: Princípios para a construção sustentável, segundo o CIB ....................17

Figura 2.10: Evolução das preocupações no setor da construção civil ....................18

Figura 2.11: Incentivos externos para a mudança de paradigma .............................19

Figura 2.12: Medidas a considerar na construção sustentável..................................220

Figura 2.13: Variações por região no consumo de eletricidade no Brasil (\% do total) por ar condicionado (esquerda) e chuveiro elétrico (direita) ..............................2 21

Figura 3.1: Tipos de metodologias e ferramentas de apoio à avaliação da

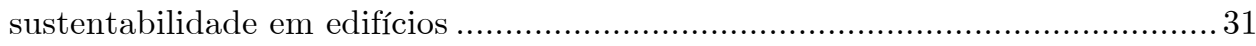

Figura 3.2: Fases do ciclo de vida englobadas em cada vertente de ACV ............... 41

Figura 3.3: Fases de implementação do ACV ………............................................... 44

Figura 3.4: Novo conceito de análise de sustentabilidade do ciclo de vida...............47

Figura 3.5: Exigência mínima para certificação no Processo AQUA ..........................55

Figura 3.6: Ponderação (em percentagem) por área do sistema LEED-NC v3.0.....57

Figura 3.7: Ponderação (em percentagem) por área do sistema LEED-NC v4.0.....59

Figura 4.1: Faseamento genérico de um empreendimento ........................................6 65

Figura 4.2: Fases de projeto em função do esforço efetuado …………………........66

Figura 4.3: Fases de um processo tradicional e de um processo integrado ...............68 68

Figura 4.4: Interfaces do processo de desenvolvimento de um empreendimento ......70

Figura 4.5: Quatro princípios orientadores para metodologia charrete ....................74 
Figura 4.6: Influência das decisões tomadas nas várias fases do ciclo de vida de um edifício nos respetivos impactos ambientais e de custos.

Figura 4.7: Durante de que fase se inicia o esforço referente à contrutibilidade. .... 79

Figura 4.8: Comparação de quando o esforço de construtibilidade normalmente se inicia.

Figura 4.9: Fases de desenvolvimento de um projeto de acordo com a norma brasileira.....

Figura 6.1: Estrutura geral da organização da Ferramenta 100

Figura 6.2: Parte da estrutura geral da Ferramenta que compõe a Fase 1 102

Figura 6.3: Pormenor da ferramenta; alguns indicadores na especialidade instalações hidráulicas

Figura 6.4: Pormenor da ferramenta; alguns indicadores na especialidade de estruturas

Figura 6.5: Exemplo da contabilização final do número de indicadores que estão a ser ou não implementados no projeto

Figura 6.6: Mapa de Processos da Fase 2 da Ferramenta. 108

Figura 6.7: Informações de referência a utilizar na especialidade de hidráulica no Anteprojeto

Figura 6.8: Atividades técnicas a produzir na especialidade de hidráulica no Anteprojeto

Figura 6.9: Documentos técnicos a apresentar na especialidade de hidráulica no Anteprojeto 


\section{ÍNDICE DE TABELAS}

Tabela 2.1: Principais barreiras à implementação da construção sustentável .........27

Tabela 3.1: Indicadores para avaliação do desempenho ambiental ...................... 45

Tabela 3.2: Categorias do Processo AQUA .................................................. 54

Tabela 3.3: Conjunto de versões LEED em função do tipo de utilização................56

Tabela 3.4: Níveis de classificação segundo a versão LEED-NC .........................58

Tabela 3.5: Diferenças entre a versão 3.0 e 4.0 do LEED-NC .............................. 60

Tabela 4.1: Associação com as fases de metodologia tradicional e as fases de projeto

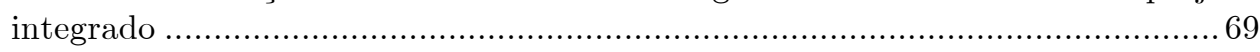

Tabela 4.2: Estratégias de sustentabilidade em projeto segundo o manual............88

Tabela 6.1: Esboço inicial da ideia para posterior desenvolvimento da ferramenta 96

Tabela 6.2: Normas introduzidas nos processos na especialidade de Instalações Hidráulicas

Tabela 6.3: Normas introduzidas nos processos na especialidade de Instalações Mecânicas

Tabela 6.4: Normas introduzidas nos processos das especialidade de estruturas, arquitetura e paisagismo e instalações elétricas................................... 114

Tabela A1: Locais Sustentáveis .................................................... 124

Tabela A2: Eficiência Hídrica v3.0 ................................................. 124

Tabela A3: Energia e Atmosfera v3.0 .............................................. 125

Tabela A4: Materiais e Recursos v3.0 .................................................. 125

Tabela A5: Inovação no Projeto v3.0 ................................................ 126

Tabela A6: Localização e Transporte v3.0 ............................................ 127

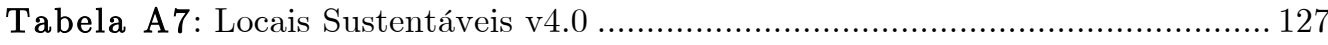

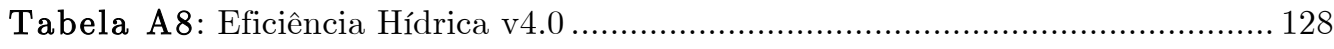

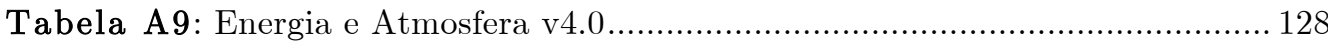

Tabela A10: Materiais e Recursos v4.0 ............................................. 129

Tabela A11: Qualidade do Ambiente Interior v4.0 ................................ 129

Tabela A12: Inovação no Projeto v4.0 .................................................. 130 


\section{SIGLAS E ABREVIATURAS}

\begin{tabular}{|c|c|}
\hline $\mathrm{ACV}$ & Análise de Ciclo de Vida \\
\hline AIA & American Institute of Architects \\
\hline AIA CC & American Institute of Architects of California Council \\
\hline AQUA & Alta Qualidade Ambiental \\
\hline AQS & Águas Quentes Sanitárias \\
\hline $\mathrm{AVAC}$ & Aquecimento, Ventilação e Ar Condicionado \\
\hline ASHRAE & $\begin{array}{l}\text { American Society of Heating, Refrigerating and Air Conditioning } \\
\text { Engineers }\end{array}$ \\
\hline BEM & Balanço Energético Nacional \\
\hline BREEAM & Building Research Establishment Environmental Assessment Method \\
\hline DAP & Declaração Ambiental de Produto \\
\hline CBCS & Conselho Brasileiro de Construção Sustentável \\
\hline $\mathrm{CEN}$ & Comité Europeu de Normalização \\
\hline $\mathrm{CFC}$ & Clorofluorcarboneto \\
\hline CIB & Conselho Internacional da Construção \\
\hline $\mathrm{COV}$ & Composto Orgânico Volátil \\
\hline CPDS & Comissão de Políticas de Desenvolvimento Sustentável \\
\hline ELCA & Environmental Life Cycle Assessment \\
\hline EUA & Estados Unidos da América \\
\hline GEE & Gases com Efeito de Estufa \\
\hline $\mathrm{IDH}$ & Índice de Desenvolvimento Humano \\
\hline IDHAD & Índice de Desenvolvimento Humano Ajustado à Desigualdade \\
\hline IPD & Integrated Project Delivery \\
\hline ISO & International Organization for Standardization \\
\hline $\mathrm{LCA}$ & Life Cycle Assessment \\
\hline $\mathrm{LCC}$ & Life Cycle Costing \\
\hline LCSA & ustainable Assessment \\
\hline
\end{tabular}


LEED Leadership in Energy \& Environmental Design

LEED-NC Leadership in Energy \& Environmental Design for New Construction

NABERS National Australian Built Environment Rating System

OMS Organização Mundial da Saúde

ONU Organização das Nações Unidas

PBMC Painel Brasileiro de Mudanças Climáticas

PIB Produto Interno Bruto

PMBOK Project Management Body of Knowledge

PMI Project Management Institute

PNUD Programa das Nações Unidas para o Desenvolvimento

QAE Qualidade Ambiental do Edifício

RCD Resíduos de Construção e Demolição

SBTool Sustainable Building Tool

SGE Sistema de Gestão do Empreendimento

SLCA Social Life Cycle Assessment

USGBC United States reen Building Council 


\section{CAPÍTULO 1 - FUNDAMENTAÇÃO E OBJETIVOS}

\subsection{Justificação}

As alterações climáticas globais, o esgotamento de recursos, a poluição, a destruição dos ecossistemas, a extinção das espécies, a deterioração da qualidade de vida, a iniquidade no acesso a recursos e ao conhecimento demonstram que os padrões que regem as atividades humanas estão a tornar-se insustentáveis (MOURÃO; PEDRO, 2012). Pela magnitude dos impactos ambientais, sociais e econômicos, a indústria da construção é uma das atividades humanas que maiores desafios apresenta hoje na definição de uma relação harmoniosa e equilibrada entre o Homem e os desígnios do desenvolvimento sustentável. Por outro lado, é também em contextos como este que se oferece a oportunidade de tomar posições e decisões importantes, que visem mitigar estes impactos. Uma construção só pode ser considerada sustentável quando as três dimensões do desenvolvimento sustentável - ambiental, econômica e social são ponderadas durante a fase de projeto (BRAGANÇA; MATEUS, 2004).

Os edifícios devem ser pensados numa lógica que contemple todas as fases do seu ciclo de vida, desde a extração da matéria-prima necessária à produção dos materiais de construção, até à desconstrução/demolição dos mesmos. Este tipo de abordagem deve ser levada em conta por todos os intervenientes responsáveis pelo edifício, desde os engenheiros, o arquiteto, o promotor, os operários, os utilizadores, etc. No entanto, a formação neste domínio deverá estar sobretudo orientada para os principais agentes que intervêm nas fases mais preliminares de projeto. Segundo Mateus (2009), as decisões tomadas na fase de concepção, são as que mais determinam os custos do ciclo de vida, o consumo de energia, a qualidade do ar no interior, o conforto dos utilizadores e o potencial de reciclagem e de reutilização dos resíduos de construção e demolição. Acresce ainda que, a capacidade de influenciar o desempenho global da construção é mais elevado nas primeiras fases de projeto e decresce exponencialmente à medida que este progride para o seu término (KOHLER; MOFFATT, 2003).

Nesta ótica, o presente trabalho irá abordar a temática da sustentabilidade na construção face aos desafios que se colocam à comunidade científica e aos intervenientes do setor da construção, com ênfase na fase de projeto, de modo a que 
se consiga, de uma forma mais eficaz e eficiente garantir a sustentabilidade de um edifício durante a totalidade do seu ciclo de vida (concepção, construção, operação e desconstrução). Admite-se que, o fato de o projeto ser pensado desde início, de forma a integrar medidas sustentáveis pode permitir uma solução mais equilibrada dos custos no ciclo de vida do edifício, trazendo desde logo benefícios, não só ambientais como também econômicos e sociais.

\subsection{Objetivo}

O objetivo do presente trabalho consiste na elaboração de uma ferramenta de apoio ao processo de concepção integrada ${ }^{1}$ de edifícios sustentáveis segundo parâmetros de certificação ambiental.

Pretende-se que a ferramenta possibilite integrar, de forma mais eficaz e eficiente, soluções construtivas com requisitos de sustentabilidade em edifícios residenciais de múltiplos pavimentos e edifícios de serviços. Os requisitos de sustentabilidade que integram a ferramenta baseiam-se no sistema de Avaliação de Sustentabilidade Leadership in Energy and Environmental Design for New Construction (LEED-NC) versão 3.0 e 4.0. Tal se deve ao fato do sistema LEED ter vindo a crescer em termos de utilização no Brasil, para além que é uma referência a nível internacional². Esta versão do LEED cobre edifícios residenciais de múltiplos pavimentos e edifícios de serviços. Porém, a utilização de sistemas de sustentabilidade não garante à partida a qualidade técnica dos sistemas e soluções que se venham a ser incorporadas no projeto. Neste sentido e com base em alguns documentos normativos brasileiros, europeus e americanos, foi também desenvolvido e incluído na ferramenta, um conjunto de diretrizes que permitam auxiliar os projetistas no que à qualidade técnica das soluções construtivas diz respeito.

Admite-se que por meio da correta utilização desta ferramenta, será possível que os diferentes requisitos que intervêm no desenvolvimento do projeto sejam considerados de uma forma integrada, permitindo que os objetivos definidos pelo Promotor da obra, em termos de sustentabilidade, possam ser mais facilmente atingidos.

\footnotetext{
1 Contemplando as principais especialidades de projetos de edifícios, nomeadamente, arquitetura, estruturas, instalações elétricas, instalações mecânicas, e instalações hidráulicas.

${ }^{2}$ A adopção do referencial LEED-NC para o desenvolvimento da ferramenta proposta é detalhada no capítulo 5 .
} 
Adicionalmente, pretende-se que a ferramenta possa ser facilmente utilizada pela equipa projetista e pelo gestor de projeto, permitindo a disponibilização dos elementos necessários no momento preciso. Não será abordada a globalidade da construção, mas sim o setor dos edifícios.

De forma resumida, os objetivos específicos da pesquisa são:

- Realizar uma analise bibliográfica sobre as técnicas de gestão integrada de projeto e das metodologias de apoio à avaliação da sustentabilidade dos edifícios;

- Analisar as principais fases e responsabilidades do desenvolvimento de um projeto, bem como é efetuada a compatibilização entre as várias especialidades;

- Com recurso ao MS-Excel, desenvolver uma ferramenta de apoio ao desenvolvimento de projetos segundo parâmetros de certificação ambiental.

\subsection{Estrutura da Dissertação}

A presente dissertação encontra-se organizada em sete capítulos, que procuram seguir uma sequência lógica com os objetivos a alcançar. De seguida descreve-se, de uma forma sucinta, o conteúdo dos sete capítulos.

- No primeiro capítulo um é feito um enquadramento ao tema, enumerando-se os objetivos preconizados e a metodologia adoptada para a dissertação;

- No capítulo dois, após pesquisa bibliográfica extensa, são abordados os princípios fundamentais da sustentabilidade. Para além disso, procede-se a uma retrospectiva dos acontecimentos marcantes e expõem-se os conceitos de desenvolvimento sustentável, construção sustentável, elencando-se as respetivas metas e desafios. Seguidamente são apresentados os impactos ambientais associados ao ciclo de vida dos edifícios e as principais barreiras existentes na implementação de práticas mais sustentáveis na construção;

- No capítulo três, procede-se à apresentação de algumas metodologias que têm sido utilizadas no apoio à construção sustentável. A partir destas metodologias, e considerando o seu grau de importância, procede-se a uma descrição da Análise de Ciclo de Vida e dos Sistemas de Certificação de 
Sustentabilidade AQUA-HQE e LEED-NC versão 3.0 e versão 4.0. Será ainda realizada uma comparação sobre estas últimas duas versões;

- No capítulo quatro é realizada uma análise aos conceitos de gestão e planejamento de projetos na ótica da sustentabilidade. É tido em consideração os temas relacionados com o faseamento do projeto, os principais intervenientes e respetivas responsabilidades, análise do processo de desenvolvimento de projeto. Será ainda abordado a importância do processo de concepção integrado para se atingirem patamares mais elevados na construção sustentável e as principais barreiras à sua implementação;

- No capítulo cinco é exposto o método de pesquisa que serviu de base ao desenvolvimento da ferramenta. Serão também destacados os recortes adoptados na pesquisa, expondo-se os principais fundamentos dos mesmos.

- O capítulo seis resulta de um cruzamento de informação dos pontos anteriores. Com base no conhecimento adquirido da pesquisa bibliográfica e com auxilio da ferramenta MS Excel, foi desenvolvido uma ferramenta de apoio ao desenvolvimento de projetos com preocupações de sustentabilidade. Será analisada a sua estrutura e a forma como se encontra organizado. Este capítulo é constituído pela apresentação pormenorizada das bases que constituem a ferramenta que este trabalho se propõe apresentar;

- Por fim, no capítulo sete serão apresentadas as conclusões mais relevantes do trabalho. Será feita uma análise relativa ao cumprimento dos objetivos inicialmente propostos, bem como as limitações da investigação e o contributo para a comunidade científica e para a indústria da construção. Serão ainda expostas algumas propostas de melhoria e recomendações para trabalhos futuros.

\subsection{Linguagem da Dissertação}

A redação da presente dissertação respeita o Novo Acordo Ortográfico da Língua Portuguesa, ratificado pelo Brasil em 2004. 


\section{CAPITULO 2 - BASES PARA A SUSTENTABILIDADE}

\subsection{Situação Global}

"O que não é sustentável não se sustentarâ" -José Rodrigues dos Santos

Desde os primórdios da Humanidade, até a um passado recente, o ser humano conviveu com a ideia de um mundo com capacidade regenerativa inesgotável e recursos intermináveis. Havia também a crença de que a capacidade decisória das sociedades era limitada, existindo um poder maior que controlaria os destinos e desígnios de todos (CREA-MINAS, 2009). Esta forma de estar conduziu a que, atualmente, a sociedade se encontre bastante preocupada com a sustentabilidade e os problemas ambientais sobre o Planeta Terra.

O problema mais premente com que se depara o nosso Planeta está relacionado com o aumento da temperatura média do ar que, por sua vez, está diretamente relacionado com a concentração de Dióxido Carbono $\left(\mathrm{CO}_{2}\right)$ na atmosfera (figura 2.1 evolução da temperatura e do $\mathrm{CO}_{2}$ na atmosfera) (TORGAL; JALALI, 2010). As emissões globais estão a crescer desde o início do século a uma média de $3 \%$ ao ano, quando o seu incremento anual se ficou por 1,5\% entre 1973 e 2000. Do volume de CO2 emitido para a atmosfera, aproximadamente $70 \%$ é proveniente da queima de combustíveis fósseis e 30\% de outros usos (TORGAL; JALALI, 2010).

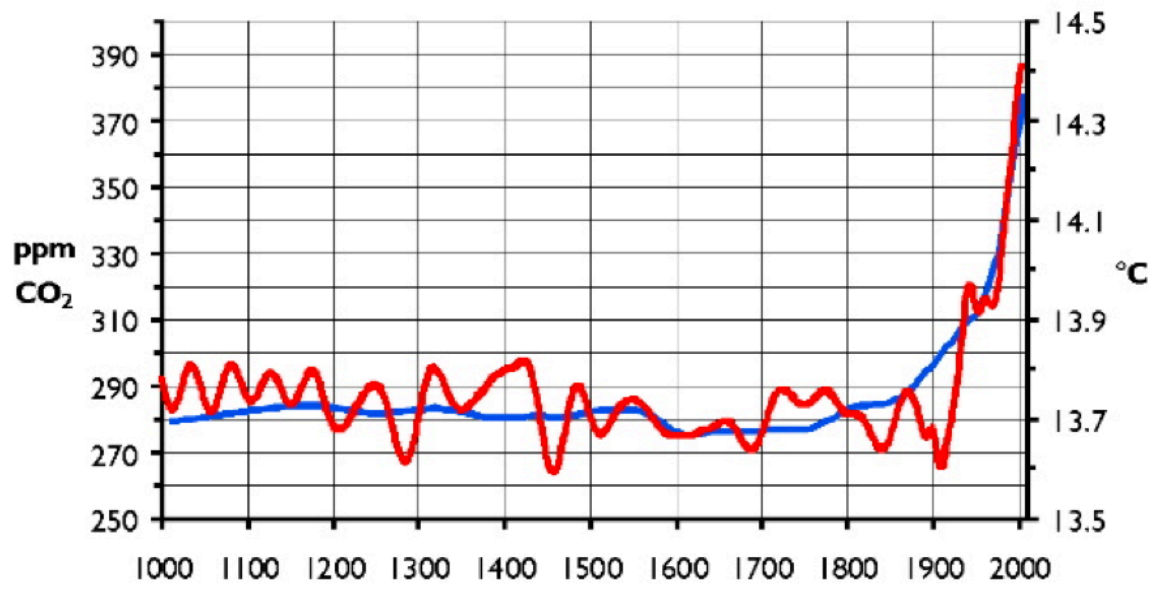

Figura 2.1: Evolução do CO2 na atmosfera (TORGAL; JALALI, 2010) 
Em Setembro de 2013 realizou-se uma reunião em Estocolmo, onde cientistas e representantes governamentais debateram um relatório sobre o que se sabe hoje acerca das alterações climáticas. O documento classifica como "extremamente provável" (95\% de confiança) que mais de metade da subida do termómetro global desde 1950 se deve às atividades humanas (GARCIA, 2013). Neste enquadramento, em 2003, a Organização Mundial da Saúde (OMS) advertiu que o aquecimento global é responsável pela morte prematura de 150 mil pessoas por ano.

Relativamente às emissões de $\mathrm{CO}_{2}$, em termos globais, a China ultrapassou recentemente os Estados Unidos, em volume bruto de emissões de $\mathrm{CO}_{2}$. Contudo esta situação tende a piorar, já que relativamente a emissões per capita este país apresenta ainda valores bastante baixos, quando comparados às emissões unitárias dos países desenvolvidos. Em 2005, a China colocava em operação uma termoelétrica a carvão a cada duas semanas.

A atmosfera é geralmente afetada não só pelo excesso de $\mathrm{CO}_{2}$, mas também por outros gases. A destruição da camada de ozono está diretamente ligada com a emissão de Gases com Efeito de Estufa (GEE), tais como o $\mathrm{CH}_{4}, \mathrm{~N}_{2} \mathrm{O}, \mathrm{PFC}, \mathrm{SF}_{6}$ e compostos halogenados, que contribuem para a formação de chuvas ácidas, para a deterioração da qualidade do ar e consequentemente a saúde humana. A presença destes gases na atmosfera constituem um fenómeno de poluição grave, o que poderá levar, inclusive, ao degelo do Ártico. Sobre este aspeto, o lobby empresarial faz com que os interesses econômicos em países como o Canadá, a Noruega ou a Rússia estejam ávidos por explorar as reservas de petróleo, gás e carvão armazenadas no seu subsolo.

Esta situação do poder econômico e do lobby empresarial é muito bem retratada no livro de Fernando Almeida "Os Desafios da Sustentabilidade" onde, refere o seguinte: "A sustentabilidade mexe com as estruturas do poder... A liberalização do comércio e as privatizações do setor de infraestruturas nas duas últimas décadas do século $X X$, transferiram uma gigantesca parcela do poder político, econômico e estratégico do Estado para as empresas" (ALMEIDA, 2007). Segundo o autor, o equilíbrio entre os objetivos econômicos, ambientais e sociais representam um dos maiores desafios do século XXI.

Por seu lado, o Brasil apesar de ter conseguido uma redução das emissões de $\mathrm{CO}_{2}$ provenientes da desmatamento, as emissões do setor energético duplicaram entre 
2005 a 2010 e há um aumento significativo da libertação de metano devido à pecuária. Em nível mundial, a alteração do uso do solo, da floresta para a agricultura, representa cerca de $20 \%$ das emissões globais de $\mathrm{CO}_{2}$ (EXPRESSO, 2013).

Os sinais do crescente aquecimento global associado às emissões de $\mathrm{CO}_{2}$ para atmosfera, está sobejamente ligada a fatores conhecidos, tais como consumo desmesurado de recursos não renováveis, destruição das florestas, proliferação de aterros sanitários, uso de produtos químicos, poluição gerada pela atividade humana, utilização de combustíveis fósseis, entre outros.

Outro aspeto a ter em consideração é o impacto causado pelo crescimento populacional, o que pode trazer importantes alterações no acesso aos recursos naturais e na cadeia de resíduos. Atualmente a população mundial situa-se nos 7,2 mil milhões de pessoas. Segundo a Organização das Nações Unidas (ONU), para o ano de 2050 a população mundial deverá ser próximo dos 9,6 mil milhões de pessoas (figura 2.2). Este crescimento populacional é o resultado de um rápido abrandamento das taxas de mortalidade, primeiro nos países mais desenvolvidos, em 1950, nos países em vias de desenvolvimento. O maior crescimento demográfico irá ocorrer na Ásia, sendo espectável um aumento de 865 milhões de pessoas, sendo a Índia o país com maior contribuição para este número. No Brasil, será espectável um aumento de 31 milhões de pessoas (ONU, 2012). Por outro lado, nos países com mais rendimentos, as taxas de crescimento caíram abaixo de $1 \%$ ao ano. 


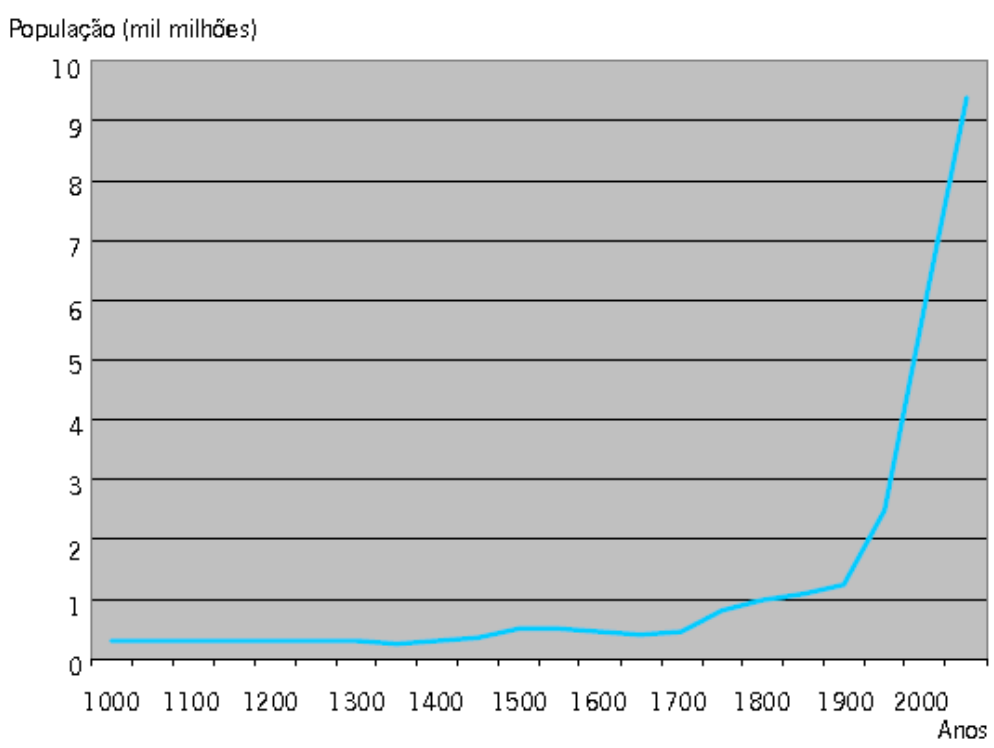

Figura 2.2: Evolução da população mundial no último milénio e evolução espectável até final do século XXI (UNEP, 2012)

De salientar, que o aumento da população mundial irá ocorrer de uma forma desigual. Este aumento demográfico irá ter maior repercussão nos países mais pobres ou em regiões menos desenvolvidas, por sua vez mais vulneráveis às alterações climáticas (PNUD, 2013).

Para além disto, a influência de algumas economias emergentes, tais como os países designados pelo acrónimo BRIC'S (Brasil, Rússia, Índia, China e África do Sul), que atualmente tentam atingir um desenvolvimento urbanístico idêntico ao dos países já desenvolvidos e obter um lugar de destaque na economia mundial. A influência destas economias emergentes têm provocado um aumento abrupto no consumo de vários tipos de recursos, e consequentemente, na poluição gerada. Na próxima década, a China, possivelmente ultrapassará os EUA como a maior economia mundial e até 2050 é espectável que o Brasil ascenda ao quarto lugar do ranking mundial (PWC, 2013).

O Homem deverá, portanto, rever as suas prioridades e entender a relatividade da espécie humana no contexto global onde habita (TORGAL; JALALI, 2010). Esta relatividade é muito bem retratada numa citação do investigador Norte-Americano Jonas E. Saulk: "If all the insects were to disappear from the Earth, within 50 years all life on Earth would end. If all human beings disappeared from the face of the Earth, in 50 years all forms of life would flourish" (TORGAL; JALALI, 2010). 


\subsection{Desenvolvimento Sustentável}

"Temos a responsabilidade coletiva de defender os princípios da dignidade humana, da igualdade e equidade a nível global. Como líderes, temos, por isso, uma responsabilidade para com todos os povos do mundo, especialmente para com os mais vulneráveis e, em particular, para com as crianças do mundo, a quem pertence o futuro"

-Declaração do Milénio, 2002

Desde os anos 80, o termo sustentabilidade tem sido mais utilizado no sentido da sustentabilidade da vida humana no planeta Terra. Esta situação levou a que em 1987, na realização do relatório de Brundtland (documento intitulado "Our Common Future") para a Comissão Mundial sobre o Meio Ambiente e Desenvolvimento, surgisse uma definição de Sustentabilidade e Desenvolvimento Sustentável como sendo "O desenvolvimento que procura satisfazer as necessidades da geração atual, sem comprometer a capacidade das gerações futuras de satisfazerem as suas próprias necessidades". Isto significa que existe, não só um limite mínimo para o bem-estar da sociedade, mas também um limite máximo para a utilização dos recursos naturais. Desta forma, é possível que as pessoas, no presente e no futuro, alcancem um nível satisfatório de desenvolvimento social, econômico e de realização humana e cultural, em simultâneo com o uso razoável dos recursos da Terra, preservando as espécies e os habitats naturais.

No entanto, a noção de desenvolvimento sustentável com a introdução das preocupações sobre o impacto ambiental no desenvolvimento econômico, assume uma dimensão adequada em 1972, quando se realizou a Conferência de Estocolmo das Nações Unidas (ONU) sobre o Meio Ambiente Humano. Este marco constituiu o primeiro grande debate internacional de discussão entre países ricos e pobres e entre diferentes grupos de interesse.

Ao longo dos anos seguintes, numa espiral crescente de importância, a ONU promoveu um conjunto de eventos centrados nas questões relacionadas com a poluição e degradação ambiental, até que atinge a sua expressão mais significativa vinte anos após a conferência de Estocolmo, na Conferência das Nações Unidas sobre Ambiente e Desenvolvimento, realizada no Rio de Janeiro em Junho de 1992 com a participação de mais de 170 países. Nessa conferência foi lavrado um documento, 
denominado por "Agenda 21". Este documento reflete um consenso mundial, sobre a importância de cada país se comprometer a pensar, global e localmente, no que diz respeito ao desenvolvimento e cooperação ambiental, de modo a que seja possível satisfazer as necessidades básicas, elevar o nível de vida de todos e obter ecossistemas melhor protegidos e geridos em prol do desenvolvimento sustentável. A "Agenda 21" segue o princípio "Pensar globalmente, agir localmente". Este é sem dúvida o resultado mais importante da cimeira do Rio (PINHEIRO, 2006) (TORGAL; JALALI, 2010). Cada país desenvolve a sua própria Agenda 21 e no Brasil a coordenação está ao cargo da Comissão de Políticas de Desenvolvimento Sustentável (CPDS) e da Agenda 21 Nacional. O processo de desenvolvimento da Agenda 21 brasileira deu-se entre 1996 a 2002; o documento foi concluído em 2002 (Agenda 21 brasileria, 2004).

Em 1997, com a assinatura do protocolo de Quioto, que representa o mais conhecido instrumento na mitigação das alterações climáticas, os países signatários incluindo Brasil, assumiram o compromisso de reduzir no seu conjunto, entre 2008 e 2012, as suas emissões de gases causadores de efeito de estufa (GEE) em 5,2\%, relativamente ao nível de emissões no ano base de 1990 (TORGAL; JALALI, 2010). Neste âmbito, salienta-se a recusa do senado norte-americano em assumir os compromissos acarretados pelo protocolo por interferirem negativamente na economia.

Cinco anos após a Convecção de Quioto, realizou-se em 2002, na cidade de Joanesburgo a Cimeira Mundial para o Desenvolvimento Sustentável. Foram reafirmados os compromissos da "Agenda 21", com proposta de reforçar os pilares do desenvolvimento sustentável: desenvolvimento econômico, desenvolvimento social e proteção ambiental, aos diferentes níveis local, regional, nacional e global (SANTOS, 2005). Também foi realçada a importância do desenvolvimento de uma nova cultura, na definição e implementação das estratégias de desenvolvimento sustentável, nas suas múltiplas dimensões num quadro de globalização.

A última Conferência significativa realizou-se no Rio de Janeiro em 2012, denominada Rio +20 . As espectativas eram elevadas, no entanto os líderes mundiais não foram suficientemente ambiciosos no compromisso de estratégias contra o consumo insustentável, culminando a conferencia com um balanço final negativo. $\mathrm{O}$ documento subscrito nesta conferência, designado por "O Futuro que Queremos" reafirma compromissos anteriores, mas acrescenta algumas novidades, tais como a 
proteção dos oceanos, a criação de objetivos globais para a sustentabilidade ou ainda, o reforço do financiamento aos países em desenvolvimento (GARCIA, 2012).

A abordagem em torno do desenvolvimento sustentável é portanto, um conceito mais abrangente do que unicamente a proteção ambiental, procurando a racionalização completa e simultânea em três grandes vertentes: econômica, social e ambiental.

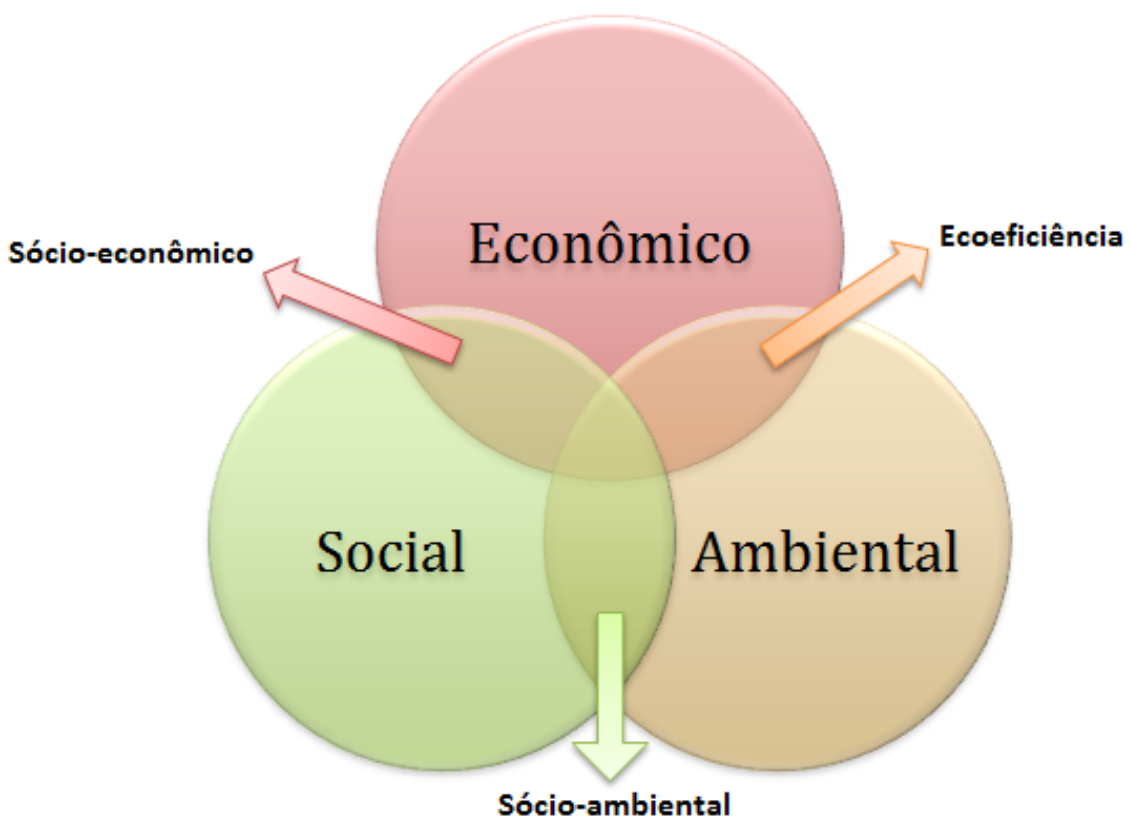

Figura 2.3: As três vertentes do desenvolvimento sustentável

Os programas sustentáveis são aqueles que resultam de um compromisso equitativo entre as três vertentes do desenvolvimento sustentável, também denominado por "triple bottom line". O que se pretende transmitir é que a dimensão ambiental seja compatível com a manutenção dos processos ecológicos, ou seja, esta não deverá ser constantemente empobrecida através da sobre-exploração de recursos e às crescentes concentrações de substâncias produzidas pela ação do homem. A dimensão social deve propiciar a equidade dos grupos sociais, direitos humanos básicos e desenvolvimento de níveis aceitáveis de qualidade de vida. Por último, a dimensão económica, representa a criação de riqueza de modo eficiente e equitativo. $\mathrm{O}$ crescimento econômico é um fator importante nesta dimensão, pois através dele se consegue elevadas taxas de empregabilidade (REIS, 2011).

Após este breve enquadramento dos acontecimentos históricos associados ao Desenvolvimento Sustentável compreende-se que as atividades humanas se 
desenvolvam sem prejuízo para a qualidade e quantidade dos recursos naturais. Infelizmente a realidade ainda está bastante distante dos ideais definidos pelo princípio do Desenvolvimento Sustentável. Segundo várias previsões, mantendo o cenário atual, em 2050 haverá um consumo equivalente aos recursos ambientais de 2,3 planetas. Atualmente esse consumo já é de 1,5 planetas, o que significa que o planeta demora 1 ano e 6 a regenerar aquilo que é consumido num ano. Seguindo o modelo atual, o Homem caminha a passos largos para uma realidade totalmente insustentável, pelo que é urgente assumir os compromissos mundiais que permitam alterar rapidamente o rumo do Planeta Terra (Global Footprint Network, 2015).

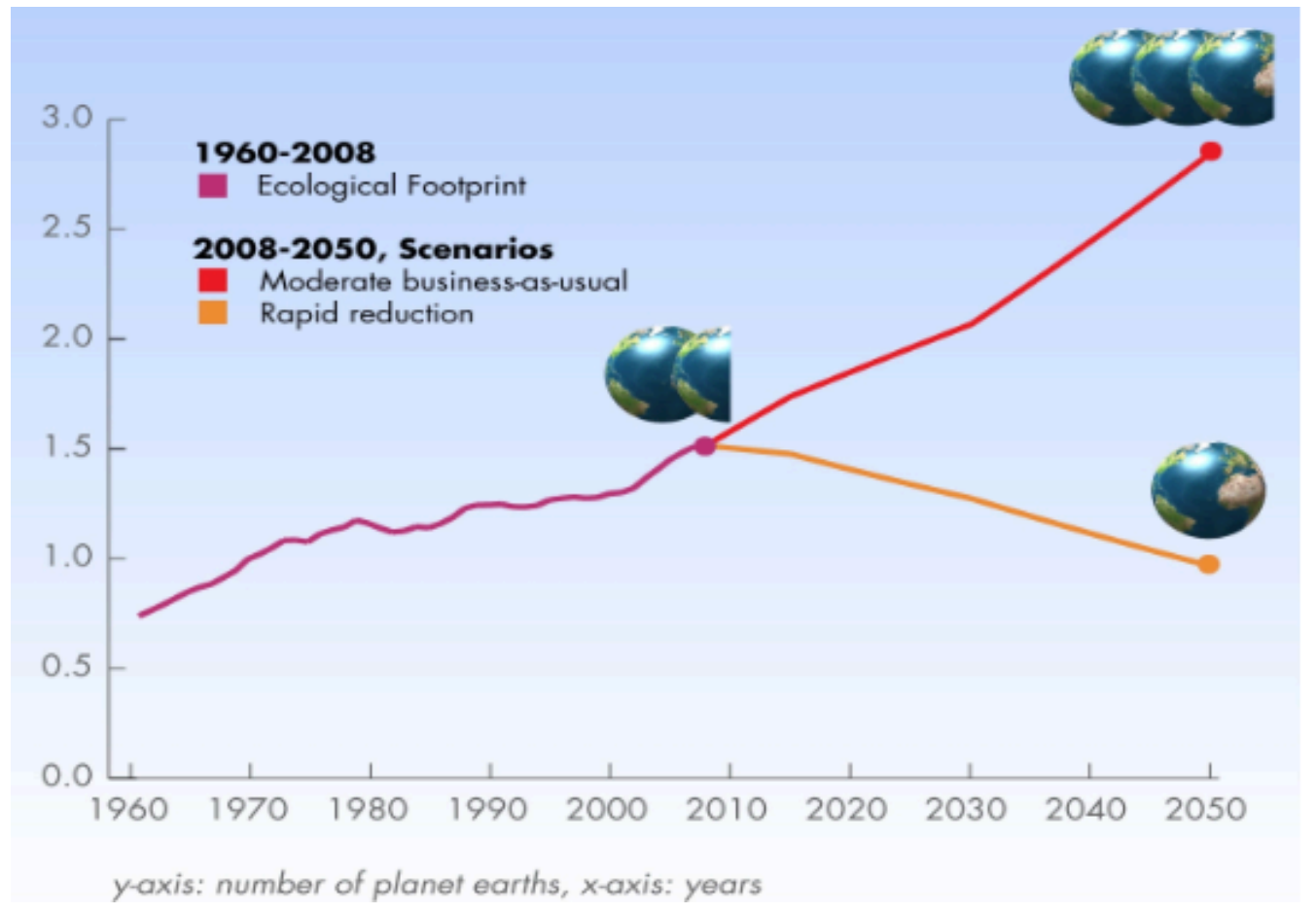

Figura 2.4: Consumo equivalente da população mundial (Global Footprint Network, 2015)

O Índice de Desenvolvimento Humano (IDH) representa um indicador composto, que com base em informação estatística disponível até ao ano precedente, medindo três dimensões básicas do bem-estar humano: rendimento, educação e saúde. Ao longo dos últimos anos, os países em todo o mundo têm vindo a convergir para níveis mais elevados de desenvolvimento humano. Segundo o relatório de desenvolvimento de 2013 do Programa das Nações Unidas para o Desenvolvimento (PNUD), o Brasil encontra-se na posição no $85^{\circ}$ lugar do ranking de 187 países, situando-se na categoria de países com um IDH elevado (0.730). No entanto, e segundo o mesmo relatório, quando o IDH é ajustado para as desigualdades internas (IDHAD) em 
saúde, educação e renda o Brasil apresenta uma queda no ranking. Neste caso, o IDHAD do Brasil situa-se em 0,531 o que significa uma desvalorização de $19.9 \%$ em relação ao IDH. A desigualdade de renda também é a principal responsável pela perda de pontos no IDHAD, seguida pela desigualdade na educação e expectativa de vida (PNUD, 2013).

Salienta-se que o IDH não inclui quaisquer considerações de ordem ecológica. A caracterização ecológica pode ser obtida através de outro indicador, por exemplo a pegada ecológica que representa o impacto ambiental do homem, traduzida em consumo de solo em hectares. Este indicador representa a área de terra necessária para suportar as necessidades de recursos e absorver os resíduos gerados por um indivíduo, uma comunidade, uma atividade, ou um edifício, no período de um ano (PINHEIRO, 2006).

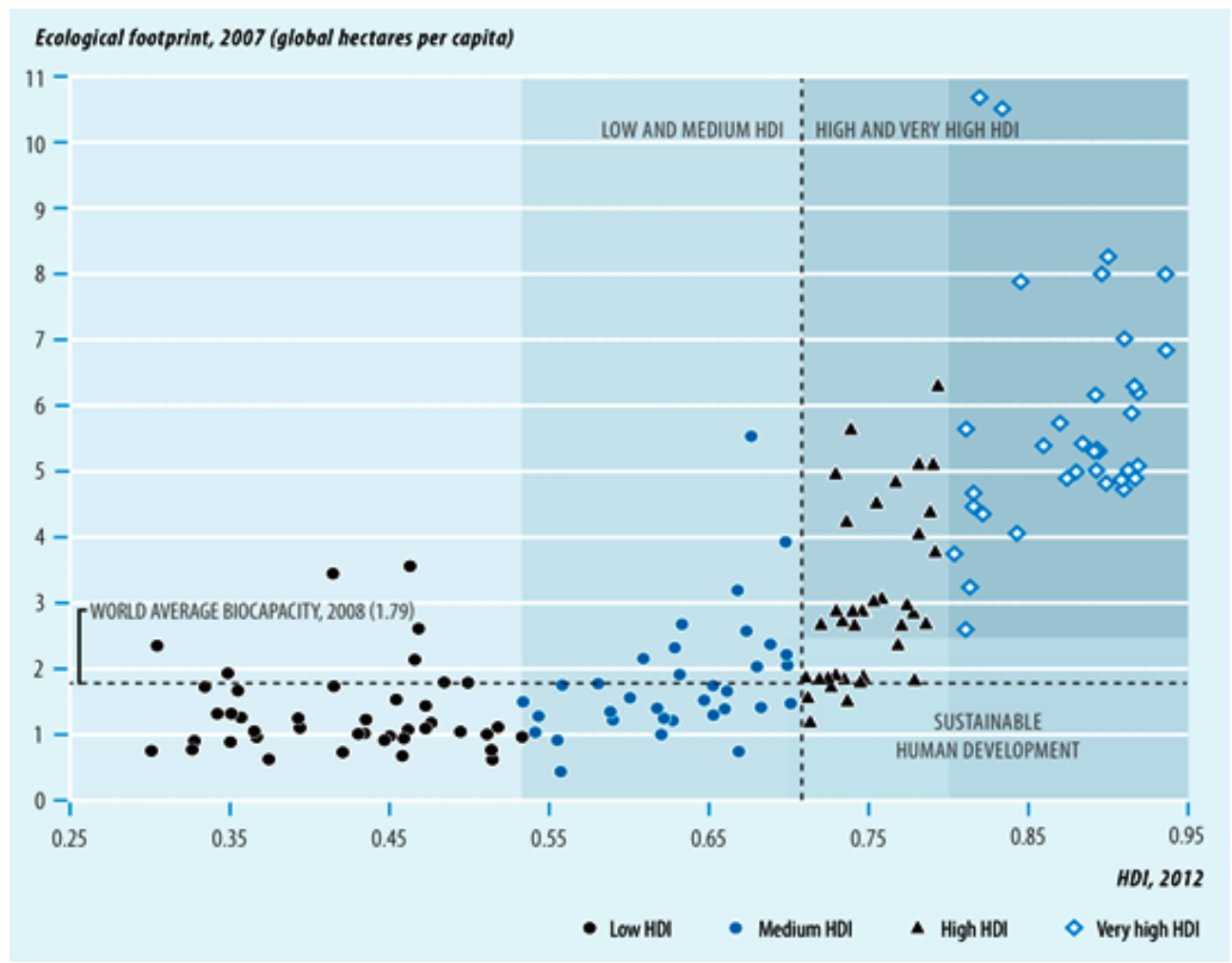

Figura 2.5: Índice de desenvolvimento humano e pegada ecológica (PNUD, 2013)

A figura 2.5 apresenta o desafio que as sociedades enfrentam, de modo a conseguirem um alto nível de bem-estar e desenvolvimento humano, garantindo ao mesmo tempo um consumo regrado dos recursos que assegure a sua disponibilidade a longo-prazo (objetivo esse que claramente não é cumprido por inúmeras nações) (MIDÕES, 2012). 
Face a este breve enquadramento, a crescente preocupação que envolve as questões relacionadas com o desenvolvimento sustentável vêm no sentido de mitigar ou reduzir até níveis aceitáveis de impacto das atividades humanas sobre os três pilares do desenvolvimento sustentável: social, ambiental e econômica. Atualmente, o elevado impacto das atividades humanas sobre o desenvolvimento sustentável pode ser suportada pelas alterações climáticas globais, pelo esgotamento de recursos, pela poluição, pela extinção de espécies e diminuta equidade no acesso aos recursos.

\subsection{Construção Sustentável}

O desenvolvimento sustentável constitui uma preocupação real para a indústria da construção, originando um esforço no sentido de transpor esse conceito para o ambiente construído, atendendo à elevada quantidade de recursos que consome, à quantidade de resíduos que produz, à sua implicação na economia dos países e à sua inter-relação com a sociedade. A construção sustentável é a resposta do mercado da construção às metas e objetivos definidos para o desenvolvimento sustentável. Além disto, estima-se que, nos países desenvolvidos a maioria das pessoas passem entre $80 \%$ a $90 \%$ do seu tempo no interior de edifícios, pelo que o edifício tem grande relevância para o bem-estar e qualidade de vida das pessoas.

No Brasil, a indústria da construção é um dos principais empregadores, responsável por $8,4 \%$ do emprego correspondendo a aproximadamente 7,8 milhões de trabalhadores e um contributo de 5,7\% no PIB brasileiro (DIEESE, 2013).

Em termos energéticos no Brasil, e de acordo com a figura 2.6, o parque edificado consumiu em $2014^{3}$ cerca de $13,7 \%$ do total de energia utilizada pelo país. Deste valor, $9,1 \%$ está associado ao uso residencial e 4,5\% aos serviços, o que equivale no total do consumo de 35,22 Mtep (milhões de toneladas de equivalente de petróleo) (BEN, 2014). As edificações residenciais foi o segmento que mais eletricidade absorveu com uma participação de 45,3\% na matriz elétrica brasileira, sendo $62 \%$ da energia consumida provém de fontes renováveis, com destaque a energia hidrelétrica (BEN, 2014). Sobre este aspeto, importa ainda referir que, apesar de uma parte significativa da energia ser proveniente de fontes renováveis, não quer necessariamente dizer que a mesma seja sustentável. Esta questão deve ser analisada

${ }^{3}$ Data do ultimo relatório disponibilizado pelo Balanço Energético Nacional 
à luz dos impactos que as infraestruturas têm sobre o meio ambiente e na comunidade local. A título exemplificativo, uma barragem pode produzir energia limpa mas, ao mesmo tempo, pode causar um forte impacto ambiental na medida em interfere negativamente nos ecossistemas ou originar um impacto social negativo, como foi o caso da barragem do Alqueva (Portugal) onde submergiu uma aldeia por completo, a Aldeia da Luz.

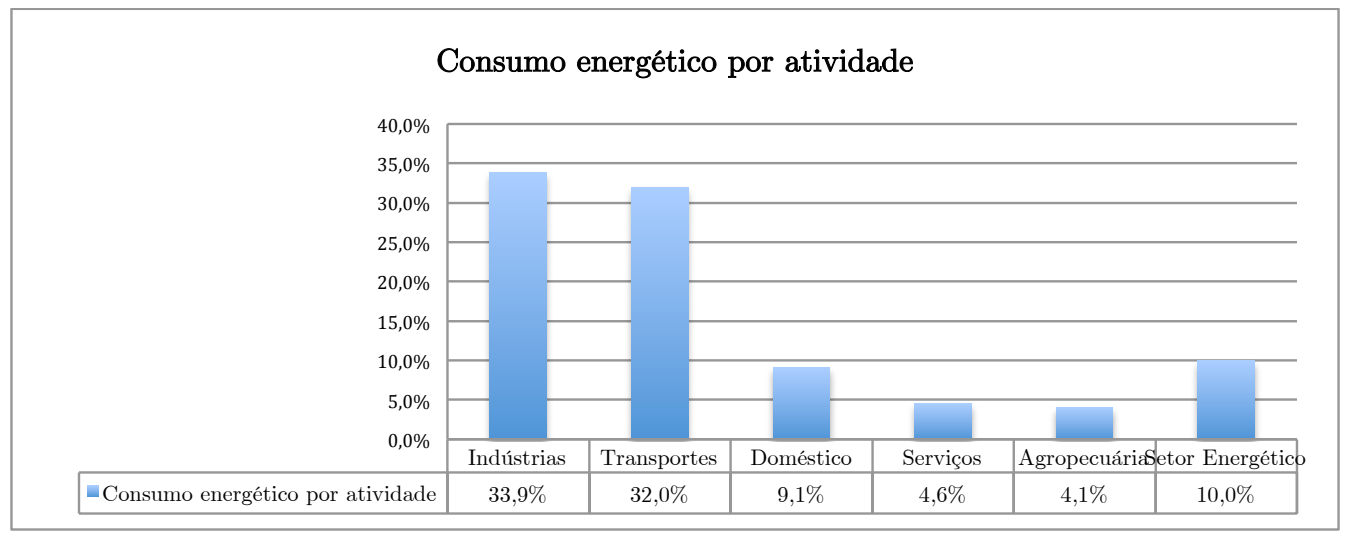

Figura 2.6: Consumos energéticos por atividade (BEN, 2014)

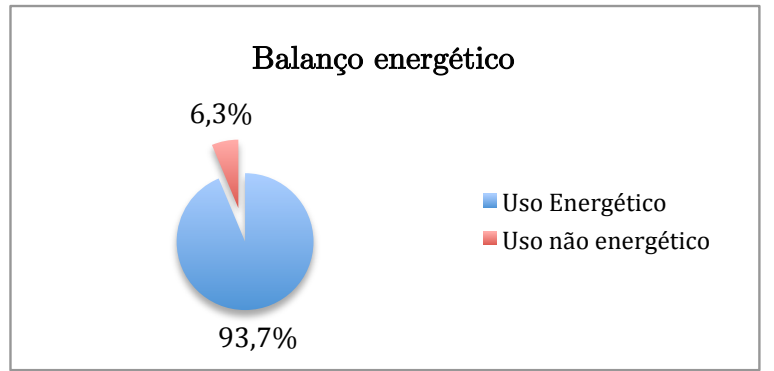

Figura 2.7: Balanço energético (BEN, 2014)

Por outro lado, o consumo energético nos edifícios tende a aumentar, na proporção direta do crescimento do nível de vida e consequente aumento das exigências de conforto individual e das famílias. Segundo o mesmo relatório do Balanço Energético Nacional (BEN), do ano de 2012 para 2013, houve um aumento no consumo de eletricidade na ordem dos $3,6 \%$, com destaque para os setores residencial e comercial, tendo sido atendido com aumento da geração térmica convencional. A participação de renováveis na Matriz energética foi de 41,0\%, que faz do Brasil uma das mais limpas do mundo. O consumo per capita de energia residencial é igualmente baixo, quando comparado com outros países (figura 2.8), aproximadamente oito vezes inferior ao dos Estados Unidos América (EUA). Esta situação deve-se ao facto da população 
brasileira, em termos gerais, ter um nível de rendimento inferior e poucos edifícios residenciais brasileiros contarem com aquecimento, função responsável por $41 \%$ do consumo de energia nas residências dos EUA (JOHN; AGOPYAN, 2013).

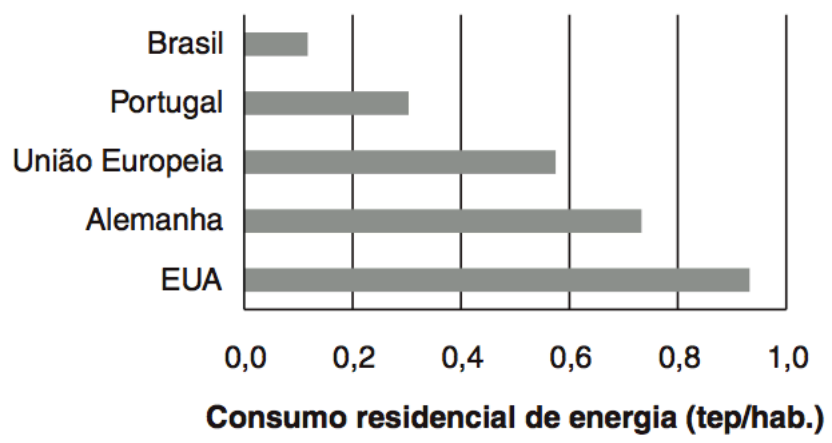

Figura 2.8: Comparação do consumo energético residencial do Brasil em outros países (JOHN; AGOPYAN, 2013)

No que se refere às matérias-primas, a indústria da construção apresenta um consumo superior a qualquer outra atividade. A nível mundial, os edifícios e ambiente construído armazenam 40\% dos materiais e 55\% das madeiras extraídas. As quantidades de resíduos são elevadas e estima-se que o edificado e atividades afins origine cerca de $40 \%$ do total de resíduos produzidos. Do total dos resíduos de construção e demolição (RCD) internacionais, cerca de $92 \%$ são atribuídos às atividades de demolição e 8\% provêm de atividades construtivas (PINHEIRO, 2006).

Também o consumo de água é preocupante pois, sendo um recurso com tendência a escassear no mundo (devido a vários fatores, tais como o rápido aumento da população mundial ou de longos períodos de seca, cada vez mais frequentes, por exemplo), todas as medidas que possam prevenir este fenómeno, permitindo assim reduzindo o seu consumo, são bem-vindas (além que permitem reduzir os custos mensais associados ao consumo).

\subsubsection{Conceitos e Evolução}

No decorrer da procura pela sustentabilidade na construção, uma das definições mais consensuais de construção sustentável foi apresentada por Charles Kibert em 1994, no Conselho Internacional da Construção (CIB), que enuncia o seguinte: "Construção sustentável é a criação e gestão responsável de um ambiente construído saudável, tendo em consideração os princípios ecológicos e a utilização eficiente dos recursos". Com base nesta definição, o CIB definiu sete princípios para a construção sustentável. 


\section{Sete Princípios da Construção Sustentável}

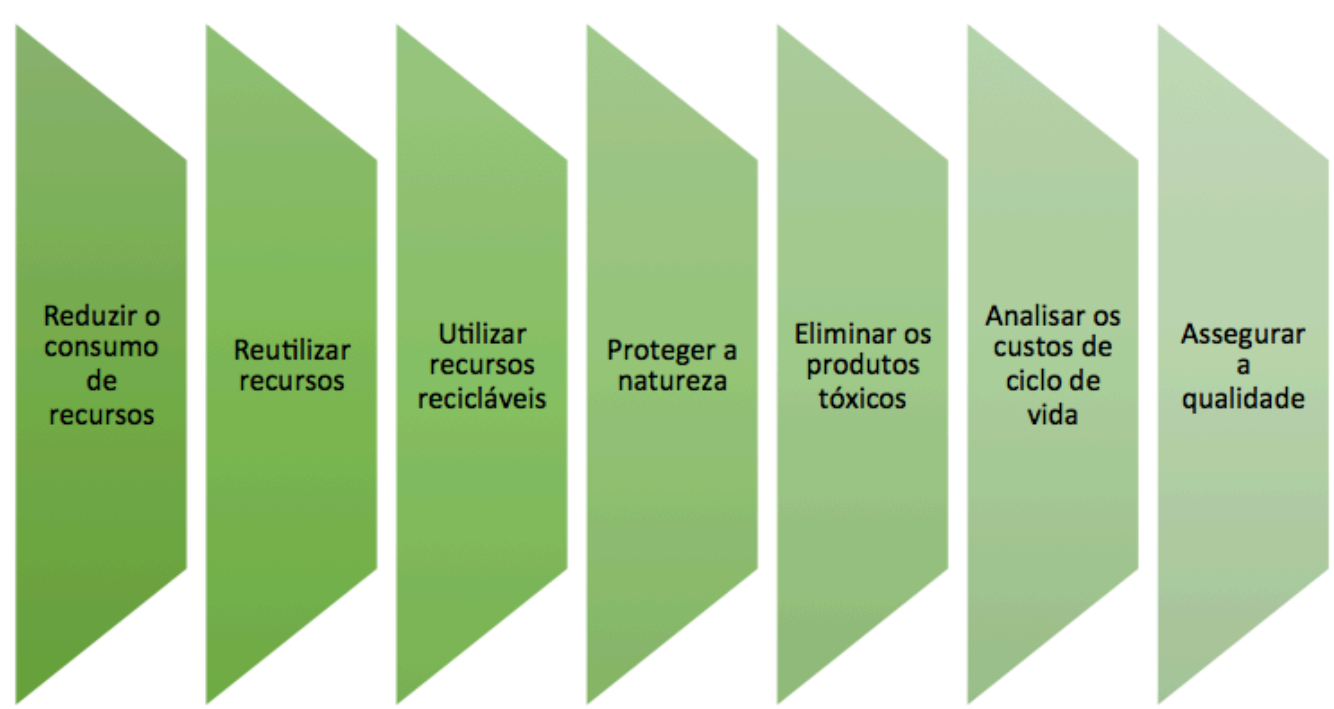

Figura 2.9: Princípios para a construção sustentável, segundo o CIB (KIBERT, 2013)

Estes sete princípios devem ser aplicados em todo o ciclo de vida de um edifício, desde a fase mais preliminar de projeto até ao tratamento dos produtos da demolição/desconstrução (MATEUS, 2009).

Mais recentemente, uma equipa de trabalho denominada CRISP (Construction and City Related Sustainable Indicatores), estabeleceu a seguinte definição para o conceito de construção sustentável: "Com a construção sustentável pretende-se que os produtos da industria da construção satisfaçam os requisitos funcionais com o menor impacto ambiental possível, enquanto promovem melhorias a nível económico, social e cultural à escala local, regional e global." Esta definição foi posteriormente adoptada pela norma ISO 21929-1. Com base neste significado é particularmente interessante observar que a ideologia de construção sustentável não se pretende unicamente melhorar o impacto ambiental das construções, mas também o conforto dos usuários e qualidade de vida em geral da população (ISO 21929, 2011).

A construção sustentável representa uma nova forma de equacionar a concepção, a construção, a operação e a desativação. Na perspetiva tradicional, uma construção só era competitiva se tivesse o nível de qualidade exigido pelo projeto, se utilizasse um sistema construtivo que otimizasse a produtividade durante a fase de construção e que desta forma conduzisse à diminuição do período de construção, permitindo uma 
maior rapidez na recuperação de investimento (MATEUS; BRAGANÇA, 2006) (PINHEIRO, 2006).

Mais tarde, com a introdução das preocupações ambientais, o conceito de qualidade na construção passou a abranger os conceitos relacionados com a qualidade ambiental. Assim surge a construção ecoeficiente. Esta pretende que o meio construído se integre em todos os aspetos dos sistemas ecológicos da biosfera durante todo o seu ciclo de vida (MATEUS; BRAGANÇA, 2006).

Por fim, a integração dos princípios da ecoeficiência com as condicionantes económicas, a equidade social e o legado cultural, coloca-nos na presença das três dimensões da construção sustentável (MATEUS; BRAGANÇA, 2006).

A figura 2.10 representa a evolução das preocupações na construção, segundo o qual o papel dos vários intervenientes nesta abordagem é decisivo.

\section{Sustentabilidade e construção}

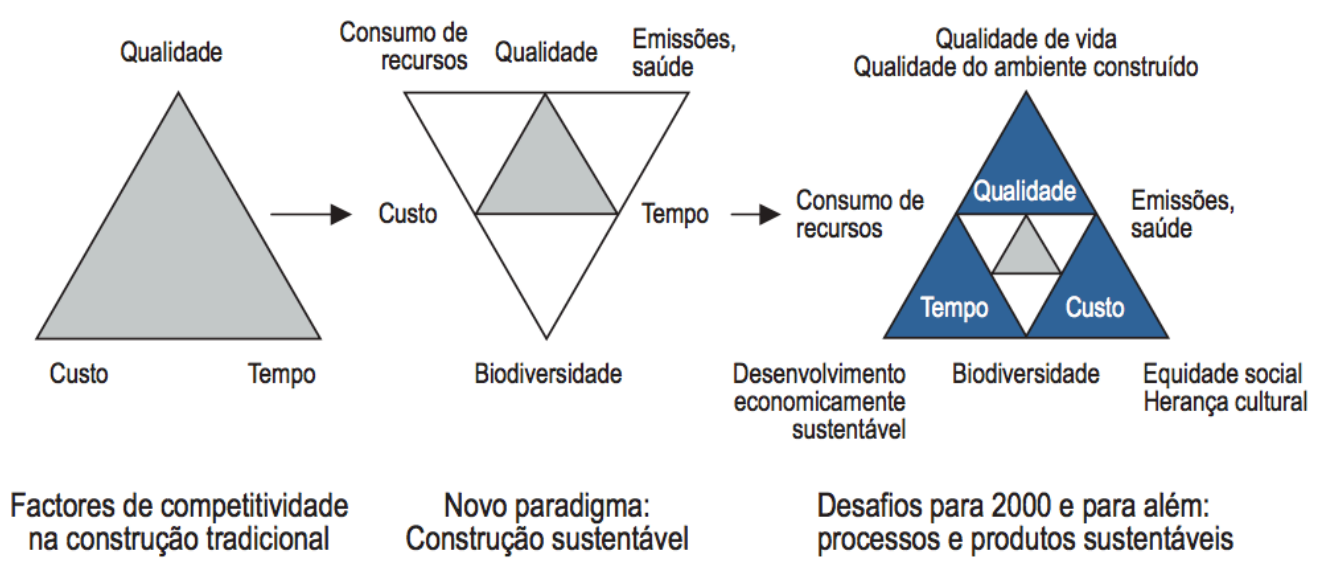

Figura 2.10: Evolução das preocupações no setor da construção civil (PINHEIRO, 2006)

Nesta abordagem, o papel dos vários intervenientes é decisivo, desde o setor de extração dos materiais, da construção, dos clientes e os responsáveis da manutenção. Este novo modo de conceber a construção procura satisfazer as necessidades humanas, protegendo e preservando simultaneamente a qualidade ambiental e recursos humanos (PINHEIRO, 2006).

Após esta análise sobre o conceito de construção sustentável, é de esperar que este se encontra plenamente incluído no domínio do conceito mais amplo de desenvolvimento sustentável. 
Da análise da figura 2.11, verifica-se que todas as ações tomadas no âmbito da construção sustentável conduzem à prossecução dos objetivos de desenvolvimento sustentável, objetivos esses que comprovam e evidenciam a interligação existente entre estes dois conceitos. Os incentivos externos para a mudança de paradigma representam diferentes desafios para a construção, sendo a estratégia da sustentabilidade uma nova abordagem que resultará uma construção sustentável, onde a atuação dos vários intervenientes garantem a sua adequação ao conceito de desenvolvimento sustentável (AMADO; FERREIRA, 2010).

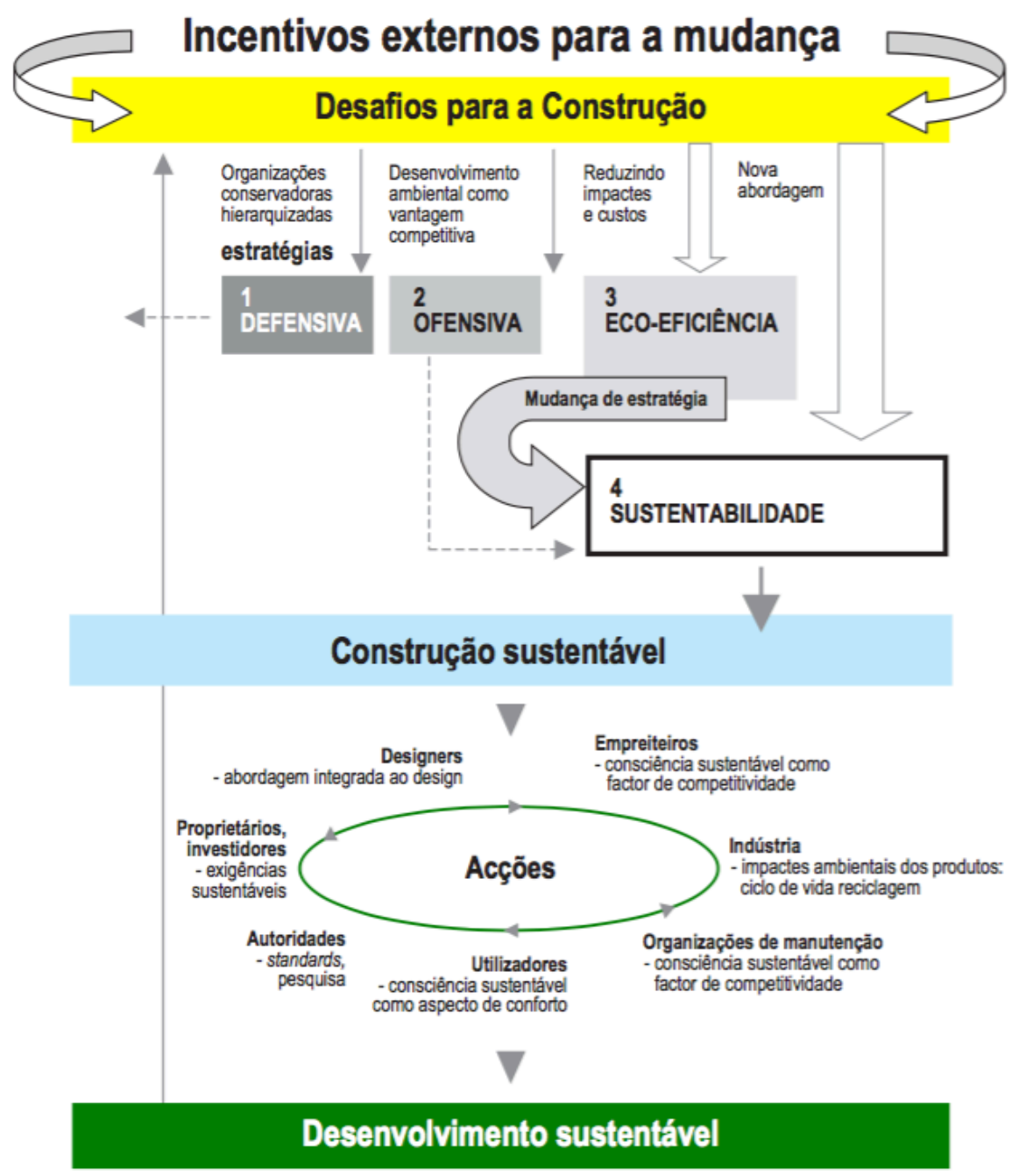

Figura 2.11: Incentivos externos para a mudança de paradigma (AMADO; FERREIRA, 2010)

Com base neste enquadramento, entende-se que para alcançar os objetivos da construção sustentável, torna-se necessário uma mudança nas práticas na concepção do projeto e também na construção, bem como uma melhor compreensão dos ciclos de recursos envolvidos e das necessidades e requisitos dos futuros utentes. Segundo, 
Mateus e Bragança (2006) é possível elencar um conjunto de prioridades (figura 2.12) que deverão ser aplicadas, por meio de uma abordagem integrada, a todas as fases que compõem o ciclo de vida de uma construção: projeto, construção, operação e desativação.

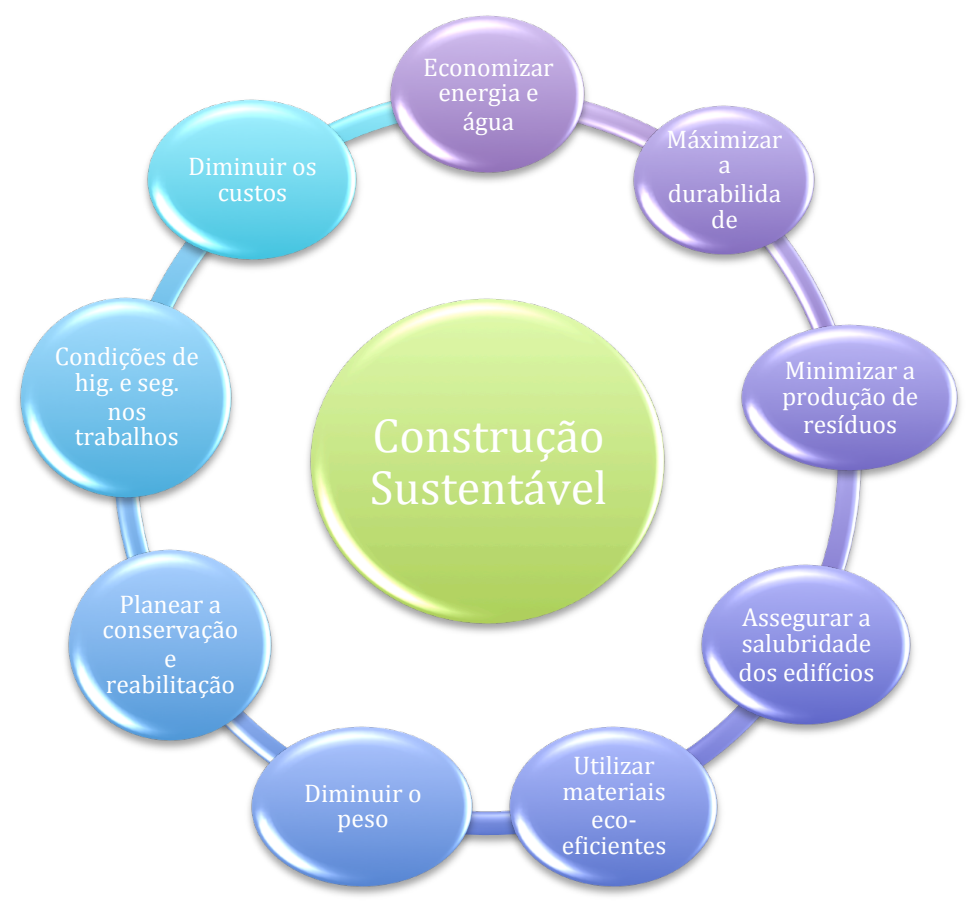

Figura 2.12: Medidas a considerar na construção sustentável, adaptado de (MATEUS; BRAGANÇA, 2006)

Atualmente, na procura de soluções que possam tornar a construção mais sustentável, alguns projetistas inspiram-se em técnicas de construção contemporânea, adaptando-as às necessidades de conforto atuais, como é o caso de construções em adobe, taipa, fardos de palha, etc.

Refere-se ainda que a construção sustentável deve ter abordagens distintas em diferentes países, de acordo com as condições econômicas, sociais e culturais, e também de acordo com o impacto ecológico sobre o ambiente local. Por outro lado, em países como o Brasil, tendo em conta a sua grande dimensão poderá ter interesse em implementar uma abordagem regional de acordo com a localização do edifício, o que implicaria diferentes soluções construtivas. 

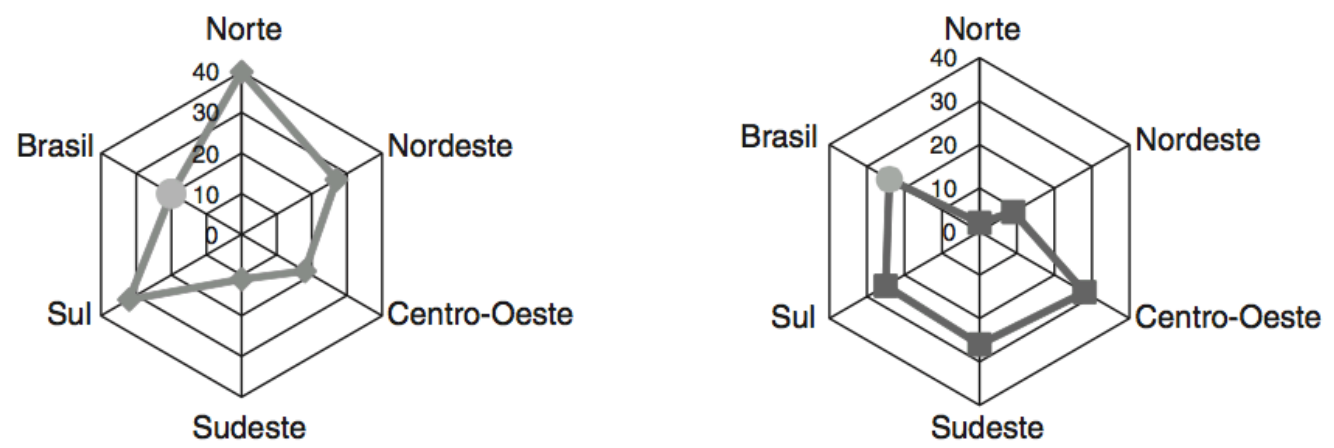

Figura 2.13: Variações por região no consumo de eletricidade no Brasil (\% do total) por ar condicionado (esquerda) e chuveiro elétrico (direita) (JOHN; AGOPYAN, 2013)

De acordo com a figura 2.13 as prioridades para redução do consumo energético variam de acordo com a região em estudo. Com efeito, no Norte e Nordeste, no que se refere ao consumo de energia, é preciso incluir estratégias para reduzir as necessidades energéticas referentes ao Ar condicionado, enquanto que, nas regiões Sul e Sudeste a questão das Águas Quentes Sanitárias (AQS) é uma prioridade. De acordo com o relatório PBMC (Painel Brasileiro de Mudanças Climáticas) observa-se uma marcada diferença de consumo de energia no setor residencial, sendo que a região Sudeste concentra mais de metade do consumo nacional $(53,6 \%)$ e $45,1 \%$ do consumo de gás liquefeito de petróleo (JOHN; AGOPYAN, 2013) (PBMC, 2013).

Para além disto, vários fatores que influenciam o consumo energético dos edifícios, sendo os mais importantes (MATEUS; BRAGANÇA, 2006):

- Grau de conforto exigido pelos utilizadores e seu comportamento;

- O número de utilizadores;

- Condições climáticas do local, onde se encontra implantado o edifício (clima mais quente ou mais frio, com maior ou menor radiação solar);

- Condutibilidade térmica dos elementos das envolventes do edifício (parte opaca e envidraçados);

- Perdas e ganhos de carga térmica associados à renovação do ar interior;

- Volume da construção (área útil e pé-direito);

- Orientação da construção;

- Área de envidraçados e sua orientação;

- Condições económicas dos utilizadores;

- Eficiência energética dos equipamentos existentes. 
Apesar do setor da construção não se restringir unicamente ao setor dos edifícios (infraestruturas, obras hidráulicas), convém realçar que os princípios da construção sustentável estão mais orientados para este setor. São várias as razões para este facto, nomeadamente, o elevado dispêndio energético, produção de resíduos e emissão de poluentes registados ao longo do período de vida dos edifícios. O mesmo não se sucede com as restantes obras da Engenharia Civil, onde o impacte ambiental se situa ao nível da escolha dos materiais a utilizar e ainda durante a fase de execução da obra (TORGAL; JALALI, 2010); acresce que neste tipo de obras deve ainda ser considerado as condições de vida e de trabalho por parte dos trabalhadores, que está ligado à dimensão social.

\subsection{Impactos Ambientais Associados ao Ciclo de Vida dos Edifícios}

Este subcapítulo irá abordar alguns dos impactos ambientais mais significativos associados aos edifícios. Na realidade, os edifícios têm incorporados em si, ao longo das várias fases do seu ciclo de vida impactos ambientais, diretos ou indiretos, mais ou menos graves. Considerar-se-á quatro fases bem distintas e de maior importância, identificando os principais impactos em cada uma delas (PINHEIRO, 2006). A figura 2.14 expõem as quatro fases principais.

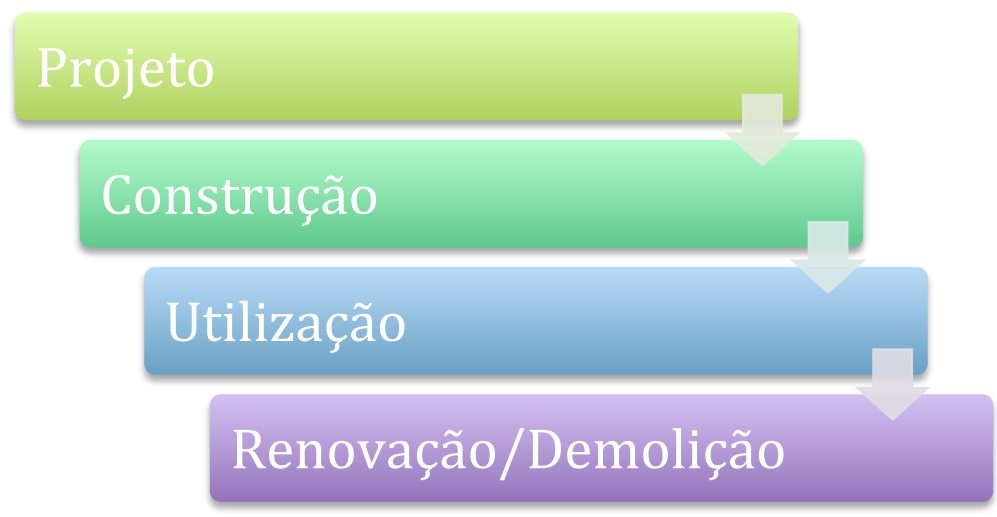

Figura 2.14: Principais fases do ciclo de vida de um edifício que induzem impactos ambientais

\section{Fase de Projeto}

Considerada a fase mais importante de todo o processo, como será detalhado no capítulo 3, nesta fase os impactos diretos a considerar não são significativos. Realmente importante nesta fase são as opções tomadas no que diz respeito ao 
desenvolvimento do projeto, tais como a escolha do local e das soluções construtivas a utilizar, os fornecedores, os materiais a utilizar, as necessidades energéticas e de consumo de água, entre outras, cujas repercussões se irão refletir nas restantes fases do ciclo de vida do edifício (PINHEIRO, 2006). Por conseguinte, todos os aspetos que possam tornar a construção mais sustentável, devem ser considerados e definidos nesta fase. É um aspeto que ainda não é atribuída a sua real importância o que acaba por tornar a construção pouco sustentável. Apesar disto, devem ser desenvolvidos esforços no sentido de aumentar a responsabilidade dos projetistas a uma reflexão na escolha materiais e soluções construtivas com requisitos de sustentabilidade e, ao mesmo tempo, promovendo uma maior interligação entre as diversas especialidades. A ferramenta que este trabalho se propõem apresentar vai neste sentido e pretende ser um instrumento facilitador para a equipa projetista no desenvolvimento de projetos com requisitos de sustentabilidade.

\section{Fase de Construção}

Na construção existem impactos diretos e indiretos, de diversas origens como irá ser analisado de seguida. Relativamente aos impactos diretos, existem um número significativo deles; opta-se por descrever apenas alguns exemplos, tais como: alterações provocadas pela intervenção na envolvente (por exemplo, impermeabilização do solo, afectação aos ecossistemas, alteração na paisagem, incomodo às comunidades locais, poluição sonora), consumos de energia e de meios de transporte (que por sua vez consomem combustível e aumentam a poluição atmosférica), consumo de água e produção de efluentes que necessitam de tratamento, utilização de materiais perigosos que na falta de um controlo eficaz pode induzir graves contaminações no solo, entre muitos outros (PINHEIRO, 2006). Relativamente aos impactos indiretos, apresenta-se também alguns exemplos, tais como: extração de matérias primas que serão posteriormente utilizadas nos materiais de construção definidos pelo projetista, a transformação ou produção desses mesmos materiais (incluindo transporte até ao local onde irão ser manufacturados), bem como os resíduos e emissões produzidas. Deve ser enfatizando que é na fase de construção que, num pequeno período de tempo, induz impactos muito significativos e gera alterações relevantes sobre a paisagem e os ecossistemas. 


\section{Fase de Utilização}

A fase de operação compreende o período de tempo que decorre entre a recepção da obra e o final do seu período de vida, incluindo também possíveis obras de manutenção e renovações pontuais (PINHEIRO, 2006). Existem diversos impactos diretos relacionados do uso do edifício, tais como: consumo de energia, de água de materiais e na produção de resíduos, de efluentes e de emissões atmosféricas. A nível energético o edifício consome energia decorrente da sua utilização, nomeadamente, iluminação, aquecimento e/ou arrefecimento. Conforme referido no capítulo anterior, os edifícios no Brasil constituem 13,9\% do total de energia consumida. Também o consumo de água representa um aspecto importante a ter em consideração. Durante o ano de 2014 o estado de São Paulo passou por um fenómeno de crise hídrica no qual os níveis de seca e redução na oferta de água potável atingiram níveis preocupantes pela diminuição drástica do Sistema Cantareira (destinado à captação e tratamento de água para a Grande São Paulo). Além disto a água consumida produz efluentes líquidos que necessitam de tratamento e como tal mais energia e recursos vão ser utilizados para o processar.

As emissões atmosféricas interiores e exteriores são um dos maiores focos de preocupação nesta fase. Conforme referido no capítulo anterior, o ser humano passa aproximadamente entre 80 a $90 \%$ do seu tempo dentro de edifícios, isto associado com a utilização de materiais que libertam substâncias nocivas para a saúde, bem como humidade, temperatura e ventilação desadequados pode originar o aparecimento de agentes patogénicos que se pode provocar desconforto e criar ou agravar distúrbios na saúde dos usuários do edifício (PINHEIRO, 2006) (SILVA, 2011). Os revestimentos interiores, como tintas de decoração, são um dos maiores poluidores do ambiente interior devido à libertação de Compostos Orgânicos Voláteis (COV) para o ar. Outro aspeto relevante são as emissões de Clorofluorcarboneto (CFC) produzindo na refrigeração de sistemas de ar condicionado e na refrigeração de edifícios, em sistemas de extinção de incêndios e em sistemas de isolamento (PINHEIRO, 2006). Refere-se ainda o amianto, formaldeído, monóxido de carbono produzido pelos veículos movidos a combustão, porão, fumo de tabaco, humidade, entre outros (SILVA, 2011).

Quanto aos impactos indiretos, destacam-se como os mais significativos a modificação do volume de tráfego local, pressão sobre os serviços urbanos existentes, possível criação de emprego, entre outros. 
Em suma, a fase de operação dos edifícios embora os seus impactos sejam mais discretos, lentos e progressivos ao longo de usualmente várias dezenas de anos, acaba por consumir recursos, gerar emissões gases com efeito de estufa, alterar os sistemas ambientais e construídos, de forma mais significativa que a fase de construção (PINHEIRO, 2006).

\section{Fase de Renovação/Demolição}

A fase de renovação ou demolição contempla uma possível renovação de grandes dimensões do edifício, que o capacite para mais umas décadas de utilização, mas também pode representar o possível desmantelamento ou demolição do edifício, concluindo assim o seu período de atividade. Esta fase compreende, na sua maioria, trabalhos de construção civil, apresentando assim impactos ambientais bastante idênticos aos da fase de construção. Opta-se por referir-se como principais impactos o consumo de materiais (embora de forma mais reduzida que na construção) e de energia, emissões atmosféricas, o ruído produzido e, assumindo especial destaque nesta fase, a produção de resíduos de construção e demolição (RCD). Durante esta fase, a reutilização e reciclagem de materiais toma particular relevância, permitindo desta forma, a redução de extração de materiais novos e a produção de resíduos. Sobre esta matéria há legislação Brasileira para regular os RCD; destaca-se a Lei Nacional sobre Resíduos Sólidos (Lei n. 12.105, 2012), a resolução do CONAMA 307 e a norma brasileira de resíduos sólidos da construção civil e resíduos inertes - aterros - diretrizes para projeto, implantação e operação (NBR 15113, 2004).

\subsection{Principais Barreiras à Implementação da Sustentabilidade na Industria da Construção}

Como se evidenciou, a construção sustentável visa o desempenho e funcionalidade do edifício com o mínimo impacto ambiental e promover melhorias ao nível econômico, social e cultural do local onde se insere. Segundo Rekola et al. (2012) a construção sustentável requer uma gestão cuidadosa no que se refere ao desempenho global do edifício; considerar os impactos ao longo do ciclo de vida do edifício e uma comunicação eficaz e de cooperação entre os vários intervenientes responsáveis pelos principais processos de decisão que ocorram nas diferentes fases de projeto, construção e utilização de um edifício. 
As particularidades do setor construtivo traduzem-se numa barreira ao atingimento dos objetivos no definidos pelo desenvolvimento sustentável ao nível da construção. Um estudo apresentado por Rydin et al. (2006), conclui que os projetistas apresentam uma elevada capacidade em utilizar conhecimentos nas diversas áreas que intervém; no entanto, quando questionados especificamente sobre a questão da construção sustentável, essa capacidade decresce significativamente.

Atualmente, as barreiras existentes para uma maior ampliação na introdução de medidas e soluções associadas à construção sustentável, têm sido estudadas por vários pesquisadores. Rekola et al. (2012) identificaram um conjunto de obstáculos à construção sustentável, sumarizadas na tabela 2.1, explicando-se algumas delas mais pormenorizadamente. 


\begin{tabular}{|c|c|}
\hline \multirow{3}{*}{$\begin{array}{l}\text { Políticas e } \\
\text { instrumentos de } \\
\text { orientação }\end{array}$} & $\begin{array}{l}\text { Embora existindo políticas de apoio à inovação e da construção } \\
\text { sustentável, as mesmas ainda são pouco utilizadas }\end{array}$ \\
\hline & Políticas ineficientes para aumentar a procura \\
\hline & $\begin{array}{l}\text { Fraca sensibilidade das entidades responsáveis nos processos de } \\
\text { financiamento e concessão de empréstimos para a construção }\end{array}$ \\
\hline \multirow{4}{*}{ Papel dos clientes } & $\begin{array}{l}\text { Falta de informação relativamente aos benefícios e custos na } \\
\text { construção sustentável }\end{array}$ \\
\hline & Fraca participação dos usuários no desenvolvimento do edifício \\
\hline & Mobilização ineficaz dos métodos de avaliação de sustentabilidade \\
\hline & $\begin{array}{l}\text { Fraca sensibilidade dos órgãos responsáveis pela adjudicação de } \\
\text { obras públicas, no sentido de incentivar a sustentabilidade na } \\
\text { construção }\end{array}$ \\
\hline \multirow{3}{*}{$\begin{array}{l}\text { Custos, riscos e } \\
\text { valor de mercado }\end{array}$} & Custos de capital tendem a ser mais elevados \\
\hline & Ausência de base de dados apropriados \\
\hline & $\begin{array}{l}\text { Articulação ineficiente entre as questões relacionadas com o } \\
\text { mercado e as políticas corporativas }\end{array}$ \\
\hline \multirow{2}{*}{$\begin{array}{l}\text { Cooperação e } \\
\text { relação entre os } \\
\text { intervenientes }\end{array}$} & Comunicação ineficaz entre os vários intervenientes \\
\hline & $\begin{array}{l}\text { Participação inadequada entre os diferentes intervenientes e as } \\
\text { várias atividades ao longo do desenvolvimento do projeto }\end{array}$ \\
\hline $\begin{array}{l}\text { Terminologia e } \\
\text { conhecimento } \\
\text { transversal }\end{array}$ & $\begin{array}{l}\text { A pluralidade do significado construção sustentável pode resultar } \\
\text { em formulações de problemas muito diferentes e soluções } \\
\text { construtivas contraditórias entre especialidades }\end{array}$ \\
\hline \multirow[b]{2}{*}{ Métodos integrados } & Pouca utilização de métodos para a gestão eficazes da informação \\
\hline & $\begin{array}{l}\text { Carência de métodos adequados para acompanhar as diferentes fases } \\
\text { de desenvolvimento de projeto e construção }\end{array}$ \\
\hline \multirow{2}{*}{$\begin{array}{l}\text { Processo de } \\
\text { inovação }\end{array}$} & $\begin{array}{l}\text { Setor da construção civil demasiadamente orientado para as } \\
\text { tecnologias convencionais }\end{array}$ \\
\hline & Mão de obra com baixo nível de especialização \\
\hline
\end{tabular}

Tabela 2.1: Principais barreiras à implementação da construção sustentável, adaptado de (REKOLA et al., 2012)

\section{Políticas e Instrumentos de Orientação}

As políticas governamentais, materializadas por meio de regulamentos, normas e taxas são um instrumento essencial para promover a construção sustentável. Para além disto, benefícios económicos associados a um nível mais elevado de sustentabilidade nos edifícios poderia levar a redução nos impostos, bem como as 
seguradoras e instituições de crédito (bancos) podiam oferecer condições mais favoráveis. Um edifício que tenha custos de ciclo de vida menores deveriam tornar os edifícios mais atrativos para os compradores e para as instituições financeiras. Por conseguinte, as normas e regulamentos que materializam as políticas relacionadas com a construção sustentável são um instrumento fundamental, devendo os governos recorrer a estas para potenciar a sustentabilidade no setor construtivos. A título exemplificativo deste tipo de políticas, o Programa Brasileiro da Qualidade e Produtividade do Habitat (PBQP-H) viabilizou a introdução de bacias sanitárias de 6 litros a custo zero para empresas e sociedades (JOHN; AGOPYAN, 2013). O Brasil dispõe ainda de duas políticas públicas de relevo, nomeadamente:

1. Instrução normativa 1/2010: Critérios de Sustentabilidade Ambiental na Aquisição de bens e contratação de serviços e obras;

2. Portal de "contratações públicas sustentáveis", pode ser acedido por meio do website - www.cpsustentaveis.planejamento.gov.br. O portal se apresenta como uma ferramenta governamental de sensibilização e orientação na temática da sustentabilidade, votado para os gestores públicos, como também para a sociedade, o qual busca disponibilizar informações sobre os diversos aspectos da compra pública sustentável.

\section{Terminologia e Conhecimento Transversal}

A incoerência na definição de construção sustentável pode resultar em formulações de problemas bastante diferentes. Esta incerteza materializa-se numa fraca sensibilidade dos principais intervenientes, dificultando o interesse dos mesmos em investir em produtos e métodos construtivos que promovam a sustentabilidade no domínio da construção. O maior problema prende-se com a subjetividade associada ao conceito "sustentável" motivada principalmente pelas diferenças políticas, tecnológicas, culturais, sociais e econômicas, existentes não só entre países, mas também, dentro de cada país e entre cada região geográfica. Mais ainda, o conceito "sustentável" não imutável ao longo do tempo, dependendo igualmente do estado de desenvolvimento científico e tecnológico em cada momento (MATEUS, 2009).

\section{Custos, Riscos e Valor de Mercado}

Este aspecto refere-se que, de uma maneira geral, a utilização de tecnologias, materiais e métodos construtivos que promovam a sustentabilidade na construção 
tendem a ter um valor de mercado mais elevado comparativamente à construção tradicional/convencionais (KIBERT, 2013). No entanto, a avaliação do desempenho económico não deve ser analisada no custo inicial da solução, mas sim considerando os custos de ciclo de vida, uma vez que podem ser compensados por meio menores custos de utilização (KIBERT, 2013). A demonstração de custos de ciclo de vida menores deviam tornar os edifícios mais atrativos não só para os compradores, mas também para as instituições financeiras. É importante estabelecer soluções de projeto equilibradas considerando não só o custo inicial do produto mas também os custos reversíveis.

Por outro lado, mesmo considerando que algumas medidas possam não ser benéficas no binómio custo/benefício, podem ter efeitos muito positivos para o ambiente. A título exemplificativo, soluções que permitam a reutilização das águas da chuva podem ser difíceis de justificar quando o preço da água potável é desproporcionalmente baixo; o mesmo raciocínio pode ser usado na questão da energia. Na realidade, os vários benefícios associados à construção sustentável, tais como uma menor manutenção e custos de utilização, uma maior durabilidade, um preço de revenda mais elevado e outras externalidades como os benefícios públicos, não são imediatamente aparente a curto/médio prazo ou na compra inicial (MATEUS, 2009). Esta situação é bem visível em algumas construções do Brasil em que a entidade construtora e/ou incorporadora não tem interesse em aumentar o custo inicial do edifício/empreendimento pois diminui a sua margem de lucro, por outras palavras, constrói-se para vender.

\section{Cooperação e Relação entre os Intervenientes; Papel dos Clientes}

Ao longo do ciclo de vida de um edifício (concepção, construção, utilização e reabilitação/demolição) participam um vasto leque de intervenientes desde os arquitetos, engenheiros, empreiteiros, promotor, usuários, entre outros. A falta de cooperação e articulação que se verifica entre estes intervenientes, principalmente na fase de projeto, traduz-se frequentemente num fraco desempenho do edifício. Adicionalmente o ciclo de vida de um edifício é particularmente longo, dificultando logo na fase de projeto uma avaliação rigorosa e precisa das mais valias associadas a determinados produtos ou elementos construtivos. Também ao nível de utilização é fundamental que exista uma conscientização por parte dos usuários para os benefícios associados à construção sustentável. A título exemplificativo, pouco adianta se um 
projetista realizar um projeto sustentável com recomendações ao nível da manutenção e utilização dos sistemas se os usuários não mostrarem preocupação durante a vida útil do edifício, tais como o potencial de reciclagem de resíduos domésticos, utilização ineficiente dos sistemas incorporados, entre outros. Por conseguinte, as mais valias previstas em projeto acabam por não se concretizar, podendo mesmo reverter em lucro para determinadas empresas ou indivíduos que atuam em setores específicos (por exemplo o energético).

\section{$>$ Processo de Inovação; Métodos Integrados}

O mercado da construção ainda se encontra demasiado preso aos métodos e tecnologias construtivas convencionais, havendo alguma inércia na adoção de soluções inovadoras pois está associada a um maior dispêndio financeiro e uma menor fiabilidade a longo prazo (MATEUS, 2009). Para que estas tecnologias possam ser introduzidas de forma sistemática na indústria da construção é necessário a adopção de métodos adequados que permitam auxiliar o desenvolvimento do projeto, bem como adaptar a formação dos projetistas, técnicos, clientes e usuários para as práticas da construção sustentável. Para além disto, e conforme referido anteriormente, falta também a atribuição de incentivos económicos a edifícios que sejam mais sustentáveis (por exemplo por meio da redução de impostos).

Outro problema deve-se à falta de investigação acerca das qualidades associadas a materiais e tecnologias construtivas, originando falta de informação acerca do real desempenho dos mesmos, provocando dúvidas aos potenciais utilizadores sobre as suas características. Acresce ainda, a dificuldade em aceder a base de dados sobre impactos ambientais associados aos produtos e sistemas construtivos, impossibilitando a comparação de soluções.

Atualmente com a crescente divulgação e utilização de softwares de Modelagem de Informação da Construção $\left(\mathrm{BIM}^{4}\right)$ permitem elaborar um modelo virtual preciso de uma edificação, auxiliando os vários intervenientes na elaboração de projetos, podendo reduzir o tempo e custo do empreendimento.

\footnotetext{
4 Acrónimo da expressão da língua inglesa "Building Information Modeling"
} 


\section{CAPÍTULO 3 - METODOLOGIAS DE APOIO À CONCEPÇÃO E CERTIFICAÇÃO DA SUSTENTABILIDADE DE EDIFÍCIOS}

\subsection{Enquadramento}

Conforme referido no capítulo anterior, com a progressiva promoção de importância ambiental e do conceito de sustentabilidade na construção, surgiu na década de 90, o conceito de construção sustentável. Este, tem como objetivo, garantir a sustentabilidade do edifício durante a totalidade do seu ciclo de vida (concepção, construção, operação e desativação), promovendo a equidade entre as três dimensões de desenvolvimento sustentável (econômica, social e ambiental) (REIS, 2011).

Neste sentido, surgiram ao longo dos últimos anos vários sistemas e ferramentas, dirigidas especificamente para avaliar a sustentabilidade do parque edificado. Em 2001, a Agência Internacional da Energia, no âmbito do projeto Annex 31, subdividiu as diversas metodologias e ferramentas associadas direta ou indiretamente à avaliação da sustentabilidade dos edifícios nas seguintes categorias (IEA, 2005).

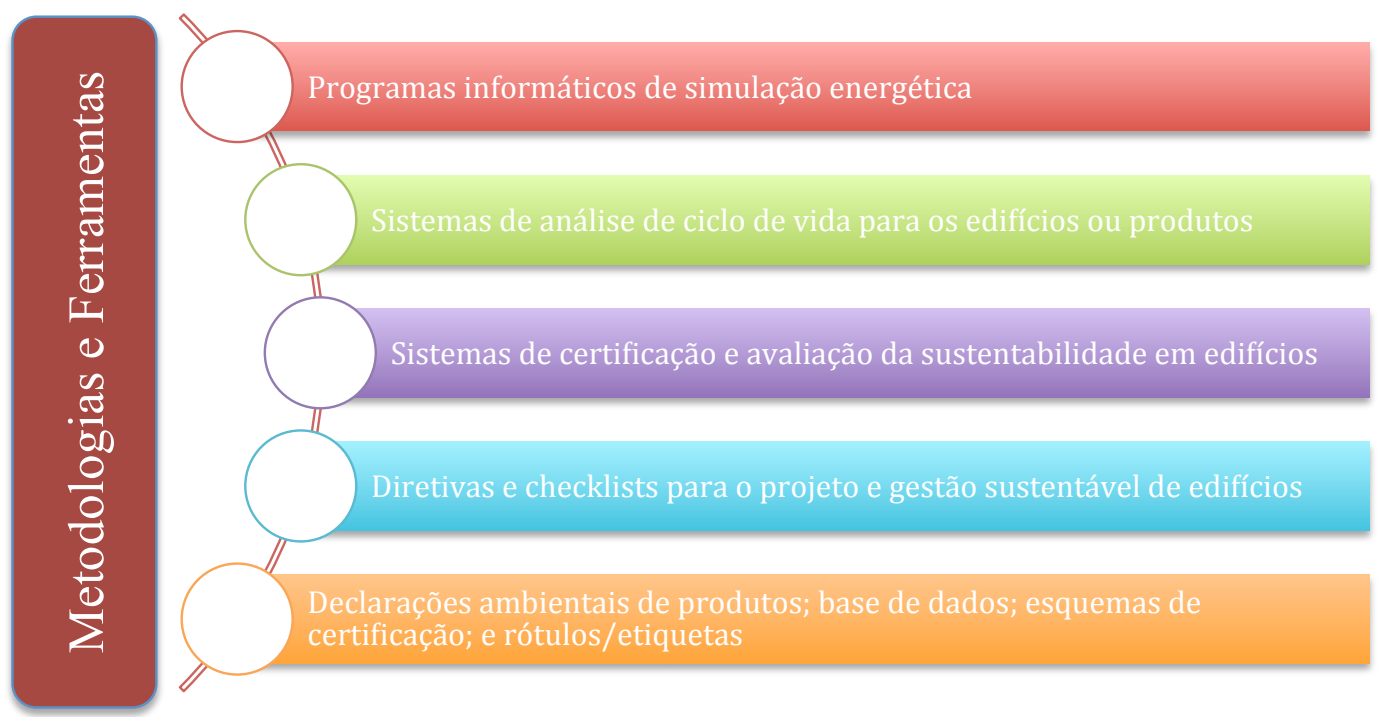

Figura 3.1: Tipos de metodologias e ferramentas de apoio à avaliação da sustentabilidade dos edifícios (IEA, 2005) 
Capítulo 3 - Metodologias de Apoio à Concepção e Certificação da Sustentabilidade de Edifícios

Todas estas metodologias apresentam um papel específico na avaliação da sustentabilidade dos edifícios. Na tentativa de se corrigirem as suas limitações será sempre indispensável uma melhoria contínua no processo, à medida que forem surgindo casos práticos e, com eles, as naturais falhas e correções a efetuar.

Salienta-se que a generalidade destes métodos é baseada numa abordagem "Bottom$U$ ", ou seja, consideram o impacte global do produto ou sistema como resultado do somatório de cada um dos seus constituintes. Com efeito, este tipo de abordagem começa por ser aplicada aos produtos de construção e soluções construtivas, para de seguida evoluir para uma aplicação generalizada aos edifícios, já que estes constituem sistemas complexos e com inúmeras variáveis ao longo do seu ciclo de vida (BRAGANÇA et al, 2010).

Apresenta-se de seguida e de forma sucinta a caracterização de cada uma das metodologias supracitadas.

1. Programas informáticos de simulação energética (Energy modeling software): Este tipo de programas auxiliam na avaliação do desempenho térmico e energético do edifício por meio de uma modelagem. Permite também analisar diferentes alternativas em projeto, sejam de componentes construtivos, sistemas de iluminação e dos sistemas Aquecimento, Ventilação e Ar Condicionado (AVAC). O programa EnergyPlus desenvolvido nos Estados Unidos é um exemplo deste tipo de programas.

2. Análise do Ciclo de Vida de edifícios ou produtos (Environmental LCA tools for building systems): As ferramentas de análise e avaliação ACV corresponde a uma metodologia de quantificação de potenciais impactos ambientais de processos e produtos durante o ciclo de vida (ORTIZ et al., 2008). Existem diversas ferramentas informáticas que permitem concretizar esta análise, tais como por exemplo o UK Ecopoints (um dos mais utilizados), Simapro, Athena, etc. Outro tipo de avaliação, semelhante ao ACV é a Análise de Custo do Ciclo de Vida (Life Cycle Cost - LCC), que permite não só contabilizar os custos imediatos, mas também contabilizar o retorno do investimento, através da redução dos consumos do edifício (custos reversíveis) (KORPI; ALA-RISKU, 2008). Refere-se ainda que em relação à indústria da construção, a União Europeia através do Comité Técnico CEN/TC 350 tem vindo a desenvolver uma série de normas para avaliar a sustentabilidade na 
construção (EN15643-1, 2010), abordando aspetos ambientais (EN15643-2, 2011) (EN15978, 2011), aspetos sociais (EN15643-3, 2012) e aspetos econômicos (EN15643-4, 2012).

3. Sistemas de certificação e avaliação da sustentabilidade em Edifícios (Environmental assessment frameworks and rating systems): Também denominados de selos verdes, estes sistemas tem como objetivo avaliar quantitativamente os aspetos da sustentabilidade dos edifícios, recorrendo a um conjunto de indicadores de diversas categorias e comunicar os resultados decorrentes da avaliação por meio de um relatório de fácil interpretação, mesmo quando consultado por pessoas não especializadas na área (FERREIRA et al., 2013). Consoante a metodologia a utilizar, as categorias e os indicadores podem variar em função do tipo de edifício; por exemplo: o sistema LEED apresenta diferentes versões consoante se o edifício é residencial, comércio ou escolas, entre outros (LEED, 2011). Dentro deste segmento de mercado, o LEED e o BREEAM são dos sistemas mais disseminados por todo o mundo. No Brasil o sistema AQUA-HQE desenvolvido pela fundação Vanzolini que, juntamente com o sistema LEED, são dos mais utilizados.

4. Diretivas e checklists para o projeto e gestão sustentáveis de edifícios (Environmental guidelines or checklists for design and management of buildings): Este tipo de ferramentas são aplicadas nas fases intermédias dos projetos de edifícios, apoiando os diversos decisores na definição do desempenho pretendido para o edifício. Desta forma os decisores de projeto, entre eles o Promotor do empreendimento, descrevem as propriedades pretendidas para a solução final de projeto através de hierarquia de requisitos e níveis de desempenho pretendido que, a serem respeitados pela equipa de projeto, se traduzem no desenvolvimento de um edifício mais sustentável (MATEUS; BRAGANÇA, 2006) (CASTRO et al., 2012). A ferramenta EcoProp desenvolvida na Finlândia ou o Environment Design Guide desenvolvido na Austrália são exemplos deste tipo de ferramentas.

5. Declarações Ambientais de Produtos (DAP), catálogos, base de dados, esquemas de certificação e rótulos (Environmental product declarations, catalogues, reference information, certifications and labels): Este tipo de 
Capítulo 3 - Metodologias de Apoio à Concepção e Certificação da Sustentabilidade de Edifícios

rótulos/declarações ambientais são documentos técnicos voluntários, verificáveis, objetivos e precisos, emitidos pelas empresas produtoras com o propósito de apresentar, de forma quantificável, o desempenho ambiental de um produto, ao longo do seu ciclo de vida. As DAP estão muito ligadas à metodologia apresentada no ponto 2 (ACV), na medida em que estas declarações permitem aos fabricantes ter a percepção dos aspetos mais negativos ao longo do ciclo de vida de um produto, podendo assim intervir de forma a mitigar estes impactos mais nefastos (MIDÕES, 2012) (MATEUS, 2011). Por outras palavras, a DAP fornece informação do desempenho ambiental durante os vários estágios do ciclo de vida de um produto. Alguns países já desenvolveram bases de dados de DAP devidamente validadas e de acesso público, por exemplo DAPhabit ou Bre evironmental profiles, desenvolvido em Portugal e no Reino Unido respetivamente. Apesar dos avanços na criação de DAP de produtos, no Brasil ainda não existe. No entanto, o Instituto Nacional de Metrologia, Qualidade e Tecnologia (INMETRO), vai iniciar a criação de um programa nacional deste tipo.

Após este breve enquadramento, é possível constatar a existência de diversas metodologias e sistemas de avaliação da sustentabilidade, cada uma com as suas valências distintas. No entanto ainda não existe uma metodologia consensual. Este fenómeno ocorre devido à subjetividade com que é interpretado o conceito "construção sustentável" que tem levado a que muitas pessoas desconfiem do mesmo. Para contrariar este fenómeno é necessário normalizar o conceito "construção sustentável" para que os diversos intervenientes do setor da construção compreendam objetivamente o conceito e as vantagens associadas e ainda para que seja possível comparar a sustentabilidade de edifícios, avaliado por metodologias diferentes. Caberá às organizações de normalização o desenvolvimento de normas que sirvam de base ao desenvolvimento de metodologias normalizadas para a avaliação do desempenho global de edifícios e construções em termos de sustentabilidade (MATEUS, 2009). Tendo em conta estes fatos, refere-se a título exemplificativo, o trabalho que tem vindo a ser desenvolvido pelo Comité Europeu de Normalização (CEN) no âmbito do Comité Técnico 350 (CEN/TC 350) que tem como objetivo padronizar/normalizar (voluntariamente) os métodos de avaliação e certificação da sustentabilidade de obras de construção, facilitando assim a interpretação e comparação dos resultados obtidos por meio de diferentes métodos. Este Comité está também encarregue de desenvolver o enquadramento normativo para as DAP de 
produtos da construção (BRAGANÇA; MATEUS, 2011). A objetividade dos resultados obtidos por meio de avaliações normalizadas permitirá promover as melhores práticas com base numa gama de incentivos, por exemplo um edifício que obtenha um elevado nível de sustentabilidade poderia levar a redução de impostos.

Paralelamente aos sistemas de avaliação de sustentabilidade de edifícios, o Brasil possui uma ferramenta on-line bastante interessante, denominada Conselho Brasileiro de Construção Sustentável (CBCS), que procura auxiliar o promotor de obra e os vários intervenientes no setor da construção na tomada de decisão para a seleção materiais e fornecedores com critérios de sustentabilidade. Esta ferramenta pode ser interessante para combater alguns problemas sócio ambientais no Brasil, no sentido que empresas ou fornecedores que não cumpram determinados requisitos, não fazem parte da lista do CBCS. A título exemplificativo, o Brasil possui um elevado número de trabalhos na construção civil informais (atividade económica não declarada). Segundo John e Agopyan (2013) em países emergentes a informalidade no trabalho pode atingir $70 \%$ da economia de toda a cadeia produtiva da construção civil, incluindo o caso das habitações nas favelas e residências das pessoas de classe financeira mais elevada, por meio de uma estratégia de aumentar os lucros no decorrer dos negócios. Este dado é bastante preocupante porque para além dos prejuízos causados pela informalidade do trabalho para o trabalhador, o Estado Brasileiro também sai lesado porque diminui a sua capacidade de planear e implementar políticas públicas apropriadas, para além que influencia as contas do setor público, nomeadamente, a Previdência Social originando um défice orçamental. O trabalho informal origina uma economia paralela, onde não há qualquer controlo da legislação ambiental ou trabalhista, dos licenciamentos, das regras de segurança e saúde no trabalho (JOHN; AGOPYAN, 2013).

A ferramenta de seleção de fornecedores elaborada pelo CBCS denominada "seis passos para seleção de materiais e fornecedores" e disponibilizado gratuitamente, as empresas que corroboram com este tipo de trabalho informal, não devem aparecer na lista (CBCS, 2015). A economia formal é também um requisito da sustentabilidade e não é apenas da responsabilidade dos governos e da indústria da construção, mas também dos cidadãos, que precisam de se envolver e estar cientes dos impactos dos seus comportamentos e atividades e, neste caso, selecionar as melhores empresas que não contribuem para esta economia paralela (JOHN; AGOPYAN, 2013). 
Para além do CBCS o Brasil possuí também o Programa Brasileiro de Qualidade e Produtividade no Hábitat (PBQP-H), criado em 1991 e coordenado pelo Ministério das Cidades que tem como principal objetivo organizar o setor da construção civil em torno da melhoria da qualidade e da modernização produtiva em conformidade com as normas técnicas. O PBQP-H procura articular com o setor privado no sentido de que este potencie a capacidade de resposta do Programa na implementação do desenvolvimento sustentável do habitat urbano. Ainda sobre este aspeto, refere-se que as empresas construtoras para aprovarem projetos juntos à Caixa Econômica Federal necessitam de estar acreditadas pelo programa PBQP-H, por exemplo o Programa Minha Casa, Minha Vida (PBQP-H, 2015).

Segundo a estrutura principal, o PBQP-H está divido em três projetos (PBQP-H, 2015):

1. Sistema de Avaliação da Conformidade de Serviços e Obras (SiAC): Tem com objetivo avaliar a conformidade de sistemas de gestão da qualidade em níveis ou estágios definidos conforme a especialidade técnica das empresas do setor de serviços e obras atuantes na construção civil, visando a contribuir para a evolução da qualidade, produtividade e sustentabilidade no setor. Atualmente já se encontram registadas aproximadamente 3.000 empresas construtoras que constitui um fator de diferenciação no mercado.

2. Sistema de Qualificação de Empresas de Materiais, Componentes e Sistemas Construtivos (SiMaC): Tem como objetivo o combate à não conformidade com as normas técnicas pertinentes de materiais e componentes da construção civil, que influenciam na baixa qualidade de obras civis. Estas ações visam gerar um ambiente de isonomia competitiva na conformidade técnica, possibilitando a formação de ambiente para evolução tecnológica, aumento dos padrões de produtividade e de redução de custos. Neste campo, existem programas setoriais de qualidade com um índice de conformidade superior a 90\%, como é o caso de blocos de concreto, cimento Portland, painéis de partículas de madeira (MDF), entre outros; no outro extremo existem programas com baixíssimo índice de conformidade, destaca-se o caso de blocos cerâmicos apresentando um índice de conformidade de apenas 7,40\% e telhas cerâmicas com 3,10\%.

3. Sistema Nacional de Avaliações Técnicas (SINAT): Tem como objetivo o desenvolvimento de procedimentos para avaliação de novos produtos para a construção, quando não existem normas técnicas normalizadas aplicáveis ao 
produto. O SINAT é proposto para suprir, provisoriamente, lacunas da normalização técnica prescritiva, ou seja, para avaliar produtos que não abrangidos por normas técnicas prescritivas.

Neste sentido o PBQP-H e o CBCS, apesar de serem entidades diferentes e com finalidades distintas no Brasil, constituem mecanismos capazes de auxiliar e promover a sustentabilidade na construção no Brasil. No entanto, para que sejam eficazes precisam de estar devidamente embasados em conhecimento na forma de diagnóstico, e que não apenas incentive à mudança, mas a torne progressivamente obrigatória, garantindo tempo e recursos para que os agentes a ela se adequem (JOHN; AGOPYAN, 2013).

\subsection{Principais Condicionantes na Avaliação da Sustentabilidade nos Edifícios}

Conforme analisado no subcapítulo anterior, as diversas metodologias tem como finalidade identificar os aspectos fundamentais da sustentabilidade e reportar informações que permitam auxiliar na tomada de decisão ao longo das diferentes fases do ciclo de vida de um edifício. Porém, apesar de existir um elevado número de metodologias de avaliação da sustentabilidade, atualmente ainda existem limitações na sua avaliação. Segundo Mateus, destacam-se as seguintes condicionantes mais relevantes na avaliação dos edifícios (MATEUS, 2009):

\section{$>$ Complexidade ao nível da concepção}

A concepção de um edifício implica analisar um conjunto significativo de materiais, tecnologias e processos. O desempenho global do edifício não resulta do simples somatório do desempenho individual de cada uma das unidades do edifício, mas sim no modo como cada uma delas se relacionam entre si, com o ambiente circundante e seus utilizadores. Estes factores introduzem complexidade no processo de avaliação e podem levar à inviabilidade do processo se esta não for limitada apenas aos aspetos que são considerados mais importantes. Por outro lado, esta simplificação na avaliação não é realizada da mesma maneira nos diversos sistemas, pois não partilham os mesmos indicadores e parâmetros. Esta situação dificulta a comparação e a própria interpretação dos resultados obtidos. 
Capítulo 3 - Metodologias de Apoio à Concepção e Certificação da Sustentabilidade de Edifícios

\section{Multidisciplinaridade das fases de ciclo de vida}

No ciclo de vida de um edifício considera-se quatro fases bem distintas e de maior importância, nomeadamente: Projeto, construção, utilização e renovação/demolição. Cada uma destas fases têm incorporados em si, impactos ambientais, diretos ou indiretos, mais ou menos graves, envolvendo um amplo conjunto de intervenientes. A otimização do desempenho no ciclo de vida de um edifício deverá envolver a participação de todos os intervenientes , o que na prática nem sempre acontece.

\section{Elevada quantidade de materiais e variabilidade}

Os edifícios incorporam centenas de materiais individuais, com impactos bastante distintos. Esta situação dificulta em efetuar uma avaliação rigorosa de todos os impactos ambientais dos materiais utilizados. Adicionalmente não é fácil encontrar bases de dados locais que expresse o inventários dos impactos ambientais associados a todos os materiais de construção utilizados. Esta situação pode levar em que alguns sistemas contabilizem apenas alguns materiais e, devido à falta de dados, não se contabilizarem outros tipos de materiais que podem apresentar elevados impactos.

\section{> Ausência de padronização de produtos}

A industria da construção tem um baixo índice de padronização, fazendo com que os processos de produção e o produto final serem quase sempre diferentes. A esta situação, acresce o facto de o edifício projetado poder ser bastante diferente do construído. Como tal, a estimativa dos impactos provocados durante a fase de construção e operação torna-se particularmente difícil de realizar.

\section{Elevada duração da fase de operação}

A fase de operação de um edifício são condicionados por vários fatores, desde fatores externos como o clima, até fatores comportamentais dos usuários. Adicionalmente a vida útil esperada para um edifício é bastante longa, quando comparado com outros produtos. Deste modo é difícil de estimar na fase de concepção o desempenho real do edifício na fase de utilização. 


\section{Diferenças entre países ao nível político, cultural, tecnológico e socioeconómico}

As assimetrias existentes entre países e, mesmo dentro de determinados países, entre regiões geográficas, justificam que, por um lado se tenham desenvolvido listas de diferentes indicadores e parâmetros, e por outro se hierarquizassem cada um deles de acordo com o contexto específico. Deste modo, deve-se evitar utilizar à escala global metodologias em que os parâmetros e respetivas ponderações não se encontrem adequadas ao ambiente em que o edifício ficará inserido.

Seguidamente irá ser detalhado a Análise de Ciclo de Vida que é largamente reconhecido como um dos principais métodos para avaliar os impactos ambientais derivados da produção de produtos e materiais construção, soluções construtivas ou o edifício no seu todo.

\subsection{Análise de Ciclo de Vida}

Os primeiros estudos relativos à análise de $\mathrm{ACV}$ remontam ao início dos anos $70 \mathrm{e}$ foram utilizados pela companhia Coca-Cola. Esta pretendia analisar os tipos de embalagens de refrigerantes e selecionar aquelas que apresentavam um melhor desempenho em relação à preservação dos recursos naturais. A partir da década de 90 surgiram os primeiros movimentos para padronização internacional da LCA, no qual destaca-se o SETAC (Society of Environmental Toxicology and Chemistry). Desde esta data, houve um notável crescimento das atividades relacionadas com a investigação relativa ao ACV, com destaque na Europa e nos EUA (FERREIRA, 2004).

Em 1992, a ISO (International Organization for Standardization) criou um comité técnico tendo em vista a normalização de um número de abordagens de gestão ambiental, incluindo o ACV. Neste enquadramento, em 1997 é publicada a primeira norma ISO da família 14040. No Brasil, a implementação é lançada em 2001, pela norma ABNT NBR ISO 14040:2001 (avaliação do ciclo de vida - princípios e estrutura), tendo sido posteriormente lançadas as normas ABNT NBR ISO 14041:2004 (Gestão Ambiental - Avaliação do Ciclo de Vida - Definição de Objetivo e Âmbito e Análise do Inventário), ABNT NBR ISO 14042:2004 (Gestão Ambiental Avaliação do Ciclo de Vida - Avaliação do Impacto do Ciclo de Vida) e ABNT NBR ISO 14043:2005 (Gestão Ambiental - Avaliação do Ciclo de Vida - Interpretação do 
Capítulo 3 - Metodologias de Apoio à Concepção e Certificação da Sustentabilidade de Edifícios

Ciclo de Vida). Entretanto, essas normas já não se encontram em vigor, tendo sido revogadas por dois documentos, nomeadamente, ABNT NBR ISO 14040:2009 (Gestão ambiental - Avaliação do ciclo de vida - Princípios e estrutura) e ABNT NBR ISO 14044:2009 (Gestão ambiental - Avaliação do ciclo de vida - Requisitos e orientações) (ABNT). A adoção destas normas confere aos estudos uma garantia de credibilidade.

O ACV, quando realizada de acordo com as normas aplicáveis permite avaliar a carga de impacto ambiental associada a um produto, processo ou serviço durante o seu ciclo de vida. Esta metodologia, apesar de orientada para produtos e materiais, pode também ser aplicada à construção. (NEIVA et al., 2012).

\subsubsection{ACV na Construção Civil}

O ACV tem como objetivo analisar e contabilizar a complexa interação de um sistema, que pode ser um material, uma componente ou um conjunto de componentes com o ambiente, ao longo das várias fases do seu ciclo de vida (PINHEIRO, 2006). Para além disto, o ACV permite igualmente uma análise de sensibilidade, identificando quais as fases ou materiais que ao longo de um ciclo de vida de um produto são responsáveis por um maior ou menor impacto ambiental. Neste sentido, é possível fazer uma análise comparativa de duas ou mais soluções, com os mesmos desempenhos funcionais, permitindo escolher aqueles com melhor desempenho ambiental.

Uma análise de ciclo de vida adequada exige a descrição e a contabilização de todos os materiais e processos integrados na solução construtiva em análise. Para além disto, podem ser realizadas vários tipos de combinações diferentes consoante o que se pretende analisar. A figura 3.2 representa a existência de quatro fronteiras distintas, em função das fases do ciclo de vida que representam (BRAGANÇA; MATEUS, 2011) (MIDÕES, 2012). 


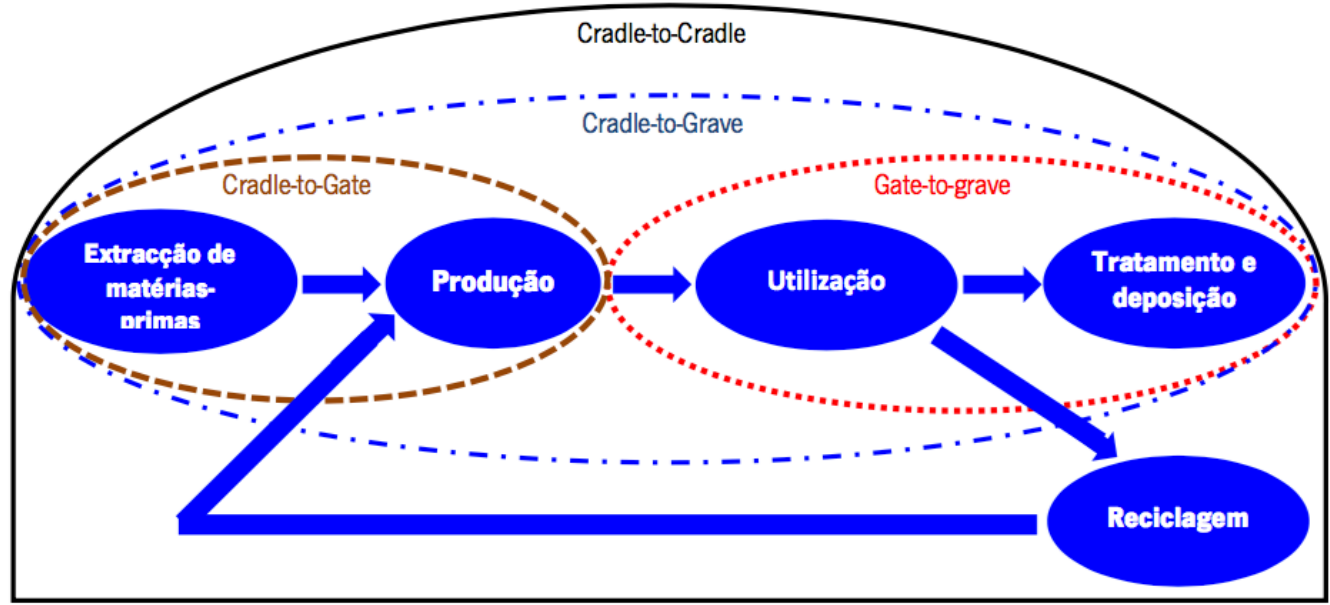

Figura 3.2: Fases do ciclo de vida englobadas em cada vertente de ACV (BRAGANÇA; MATEUS, 2011)

Na construção civil, podem ser feitas diferentes análises do ciclo de vida, dependendo do tipo de abordagem pretendida, designadamente (BRAGANÇA; MATEUS, 2011):

- Cradle-to-Gate (berço ao portão): Consiste numa análise que contempla os processos desde a extração das matérias-primas até à respetiva produção e tratamento das mesmas. O processo de transporte até ao utilizador final já não é abrangido por esta análise;

- Cradle-to-Grave (berço ao túmulo): Engloba todo o ciclo de vida do produto ou sistema, desde extração das matérias-primas até à disposição final;

- Cradle-to-Cradle (berço-ao-berço): Esta análise é a mais abrangente de todas, contempla todas as fases do Cradle-to-grave, levando ainda em consideração a fase do fim de vida como um processo de reciclagem

A última análise Gate-to-grave (portão ao túmulo) não é muito utilizada uma vez que não contempla as fases iniciais (extração das matérias primas e produção) na análise do ciclo de vida. O ACV permite a comparação de entre várias soluções alternativas equivalentes, do ponto de vista funcional, mas apresentam diferenças em relação ao seu impacto ambiental.

\subsubsection{Métodos Disponíveis na Análise do ACV}

Atualmente existem vários métodos e ferramentas que permitem avaliar o ciclo de vida dos edifícios. A maioria dos métodos opta por recorrer a um conjunto de indicadores que permitem quantificar os impactos ambientais dos edifícios. Os 
sistemas permitem identificar o fluxo de materiais, energia e resíduos gerados por um edifício em cada uma das fases, desde a extração até à desconstrução final.

No domínio das metodologias de apoio à sustentabilidade na construção é amplamente aceite que o método ACV é, possivelmente, a melhor abordagem para avaliar os efeitos ambientais, de um material ou produto. Contudo, a adoção da análise ambiental de ciclo de vida em edifícios constitui uma tarefa complexa e morosa, uma vez que a construção incorpora centenas ou até milhares de diferentes produtos no mesmo projeto e envolve dezenas de empresas e intervenientes (BRAGANÇA; MATEUS, 2012). Adicionalmente, o estudo do ACV de um edifício é diferente do estudo de produtos isolados, por esta razão, um ciclo de vida esperado para um edifício (com mais de 50 anos) é relativamente mais longo quando comparado com outro produto isoladamente (semanas ou meses). Também se admite que as ferramentas ACV atualmente disponíveis no mercado, não são utilizadas como seria desejável pela maior parte dos projetistas e dos intervenientes envolvidos no processo da construção. Devido a sua complexidade, a maior parte das ferramentas existentes foram desenvolvidas e são utilizadas sobretudo por especialistas, e na maioria das vezes a nível da pesquisa (BRAGANÇA; MATEUS, 2012) (MATEUS, 2011). De forma a ultrapassar esta situação e promover a utilização prática, os sistemas de certificação mais conhecidos simplificaram a análise ACV. Atualmente encontram-se disponíveis no mercado métodos simplificados e que se encontram integrados nos sistemas de certificação, por exemplo, o método UK Ecopoints desenvolvido pelo BRE. Um ecopoint corresponde a uma unidade de medida de impacto ambiental que é mensurável através das seguintes variáveis:

i. Extração de minerais;

ii. Consumo de combustíveis fósseis;

iii. Transporte de cargas e mercadorias;

iv. Toxidade do ar para o homem;

v. Toxidade da água para o homem;

vi. Deposição de resíduos;

vii. Extração de água;

viii. Acidificação;

ix. Eutrofização; 


$$
\begin{array}{ll}
\text { x. } & \quad \operatorname{Smog}^{5} \text { de verão; } \\
\text { xi. } & \text { Alteração do clima. }
\end{array}
$$

Todas estas variáveis mencionadas são indicadores das cargas ambientais que podem ocorrer desde as fases de extração, transformação, fabrico, transporte, uso dos produtos no edifício e deposição final. Salienta-se, no entanto, que o resultado do cálculo efetuado pelo Ecopoints utilizando as respetivas variáveis supracitadas, poderá não ser o mesmo em relação a outro método de avaliação de sustentabilidade e, consequentemente, os resultados da avaliação do desempenho ambiental não são semelhantes nem comparáveis.

Neste sentido, como os estes sistemas de certificação incorporam abordagens ACV simplificadas para uma utilização prática não são baseados num sistema ACV normalizado. Assim, a avaliação dos impactos ambientais do ciclo de vida varia de acordo com o sistema usado e, por conseguinte, os resultados da avaliação são diferentes e não são comparáveis. Tendo em conta estes factos, e conforme explicado anteriormente, foi criado pelo Centro Europeu de Normalização (CEN), o Comité Técnico CEN/TC 350, que tem como objetivo padronizar os métodos de avaliação de sustentabilidade, facilitando assim a interpretação de resultados e a comparação entre resultados de diferentes avaliações de sustentabilidade do edificado europeu.

Segundo a norma ISO 14040, e conforme representado na figura 3.3 a implementação de uma análise ACV deve ser desenvolvido em quatro etapas distintas, nomeadamente:

- Definição do objetivo e do âmbito;

- Inventário de ciclo de vida;

- Avaliação dos impactos de ciclo de vida;

- Interpretação.

\footnotetext{
${ }^{5} \mathrm{O}$ termo smog resulta da junção das palavras de língua inglesa smoke (fumaça) e fog (nevoeiro), que significa nevoeiro contaminado com fumaça.
} 
Capítulo 3 - Metodologias de Apoio à Concepção e Certificação da Sustentabilidade de Edifícios

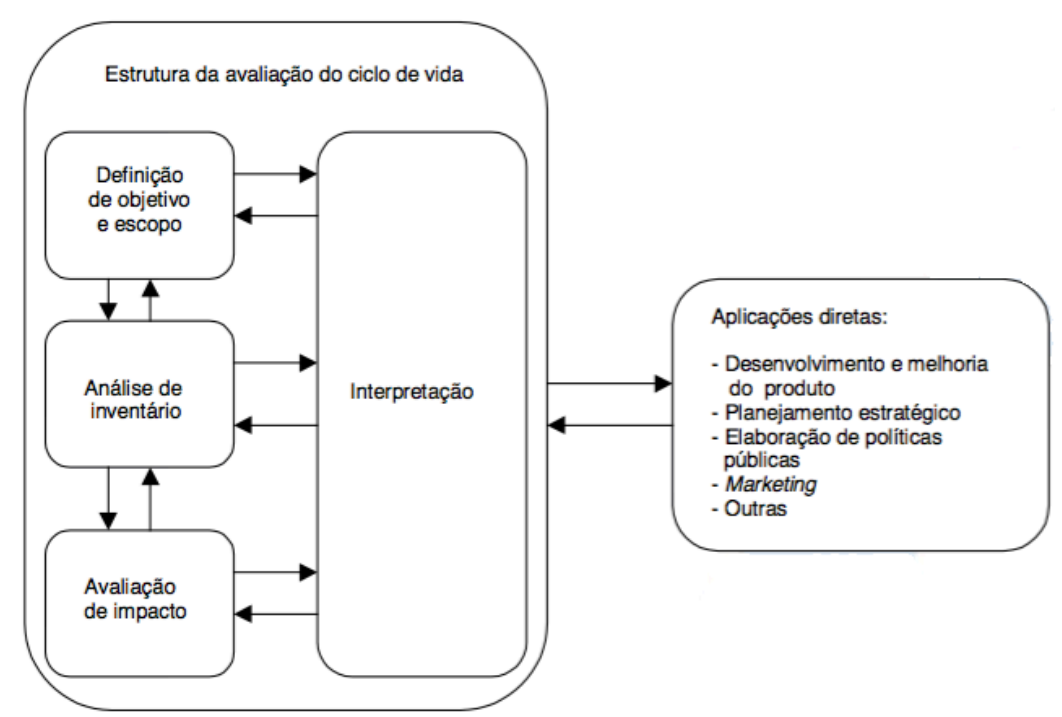

Figura 3.3: Fases de implementação do ACV (NBR ISO 14040, 2009)

A estrutura da avaliação de ciclo de vida é essencialmente um processo interativo. A primeira fase inicia-se pela definição do Objetivo e Âmbito, onde são definidos os propósitos para a análise e as fronteiras dos sistemas que (temporais, tecnológicas e geográficas) orientarão os processos subsequentes. Nesta fase, são definidos as principais categorias de impacto ambiental a utilizar. A norma EN 15978:2011 (desenvolvida pelo CEN TC 350) introduz o método de cálculo de desempenho ambiental, que abrange todas as fases do ciclo de vida da construção, nomeadamente, fase de montagem, operação, manutenção e fim de vida. Segunda esta norma, os indicadores de desempenho ambiental podem ser subdivididas em três grupos:

i. Indicadores que expressam impactos ambientais;

ii. Indicadores que expressam a utilização de recursos;

iii. Indicadores que expressam informação ambiental adicional.

Cada grupo está associado a um conjunto de indicadores que avaliam o desempenho ambiental. Os indicadores que expressam os impactos ambientais, quando se pretende realizar uma análise de ciclo de vida, são: 


\begin{tabular}{|c|c|c|}
\hline $\begin{array}{c}\text { Indicadores que } \\
\text { expressam impactos } \\
\text { ambientais }\end{array}$ & $\begin{array}{c}\text { Indicadores que } \\
\text { expressam a utilização } \\
\text { de recursos }\end{array}$ & $\begin{array}{l}\text { Indicadores que } \\
\text { expressam informação } \\
\text { ambiental adicional }\end{array}$ \\
\hline $\begin{array}{c}\text { Alterações climáticas expressas } \\
\text { em Potencial de Aquecimento } \\
\text { Global (GWP) }\end{array}$ & $\begin{array}{l}\text { Utilização de energia primária } \\
\text { renovável, excluindo os recursos } \\
\text { utilizados como matéria-prima }\end{array}$ & Deposição de resíduos perigosos \\
\hline $\begin{array}{c}\text { Destruição da camada de ozono } \\
\text { estratosférico (ODP) }\end{array}$ & $\begin{array}{l}\text { Utilização de energia primária } \\
\text { renovável, utilizada como } \\
\text { matéria-prima }\end{array}$ & $\begin{array}{c}\text { Deposição de resíduos não } \\
\text { perigosos }\end{array}$ \\
\hline $\begin{array}{l}\text { Potencial de acidificação do solo } \\
\text { e da água (AP) }\end{array}$ & $\begin{array}{l}\text { Utilização de energia primária } \\
\text { não-renovável, excluindo os } \\
\text { recursos utilizados como } \\
\text { matéria-prima }\end{array}$ & $\begin{array}{l}\text { Deposição de resíduos } \\
\text { radioativos }\end{array}$ \\
\hline Potencial de eutrofização (EP) & $\begin{array}{l}\text { Utilização de energia primária } \\
\text { não-renovável, utilizada como } \\
\text { matéria-prima }\end{array}$ & Componentes para reutilização \\
\hline $\begin{array}{l}\text { Formação de ozono troposférico, } \\
\text { expresso em oxidantes } \\
\text { fotoquímicos (POCP) }\end{array}$ & $\begin{array}{l}\text { Utilização de materiais } \\
\text { secundários (reutilização e } \\
\text { coprodutos) }\end{array}$ & Materiais para reciclagem \\
\hline $\begin{array}{l}\text { Potencial de esgotamento de } \\
\text { recursos abióticos, exceto } \\
\text { combustíveis fósseis } \\
\text { (ADP_recursos) }\end{array}$ & $\begin{array}{l}\text { Utilização de combustíveis não- } \\
\text { renováveis secundários } \\
\text { (coprodutos) }\end{array}$ & $\begin{array}{c}\text { Materiais para valorização } \\
\text { energética }\end{array}$ \\
\hline- & $\begin{array}{l}\text { Utilização de combustíveis não- } \\
\text { renováveis secundários } \\
\text { (coprodutos) }\end{array}$ & Energia exportada para a rede \\
\hline- & Consumo de água potável & - \\
\hline
\end{tabular}

Tabela 3.1: Indicadores para avaliação do desempenho ambiental (EN15978, 2011)

A segunda fase consiste na análise do inventário do ciclo de vida, que compreende a recolha e verificação de dados para cada unidade de processo, considerando todas as entradas e saídas associados ao sistema em causa. Trata-se de um processo moroso devido à necessidade de contabilizar todos os materiais que integram as tecnologias construtivas e identificar e localizar as empresas que os produzem. As informações devem estar associadas às várias fases do ciclo de vida do edifício. Nesta etapa é necessário uma preocupação e seleção criteriosa da informação a utilizar, pois muitas das fontes de onde provêm estes dados são de origem desconhecida ou pouco fiável. Se forem utilizados dados não adequados ao sistema, corre-se o risco de obter resultados afastados da realidade. Nesta etapa é bem evidente o processo iterativo do sistema, na medida em que, o utilizador vai sucessivamente melhorando a qualidade da informação compilada, tendo sempre como meta o cumprimento dos requisitos definidos no Objetivo e Âmbito (BRAGANÇA; MATEUS, 2012) (MIDÕES, 2012) (NEIVA et al., 2012) (ISO14040, 2011).

A terceira fase de avaliação de impacto ambiental consiste na interpretação e avaliação dos potenciais impactos associados aos materiais aplicados. Segundo a 
Capítulo 3 - Metodologias de Apoio à Concepção e Certificação da Sustentabilidade de Edifícios

norma ISO 14040, esta fase encontra-se dividida em duas etapas obrigatórias (classificação e caracterização) e duas opcionais (normalização e agregação). Refere-se ainda que, só se poderá considerar análise ACV se as duas etapas obrigatórias forem incluídas no estudo, caso contrário, será apenas um Inventário de Ciclo de Vida (ICV). A etapa de classificação consiste na distribuição dos resultados na fase ICV pelas diversas categorias de impacto. A etapa de caracterização compreende o estudo da contribuição relativa de cada um dos resultados no valor do indicador de cada categoria de impacto ambiental. A etapa normalização permite a comparação dos mesmos, entre os diversos tipos de categorias ambientais, através da normalização dos resultados obtidos. A etapa de agregação consiste, na atribuição de um peso a cada categoria de impacto ambiental, permitindo determinar a contribuição relativa de cada categoria para os indicadores globais. (ISO14040, 2011) (BRAGANÇA; MATEUS, 2012).

Os métodos de avaliação do impacto de ciclo de vida compreendem uma análise de entrada e saída de materiais, de consumos de energia e emissões para o meio ambiente de um produto ao longo do seu ciclo de vida. Apesar de existir uma vasta gama de categorias de impacto são, normalmente, classificadas de duas formas dependendo do tipo de abordagem: intermédios (midpoints) ou finais (endpoints). Os primeiros têm uma abordagem orientada para o problema, ou seja, refletem o mecanismo ambiental e são indicadores para o impacto ambiental. Os segundos têm uma abordagem orientada para os danos ou consequências, tais como preocupações ambientais para a saúde humana, disponibilidade de recursos para a geração futura, extinção de espécies, entre outros (UNEP, 2012) (BRAGANÇA; MATEUS, 2012).

\subsubsection{ACV e os Três Pilares do Desenvolvimento Sustentável}

Conforme referido anteriormente, nomeadamente no capítulo dois, os programas sustentáveis são aqueles que resultam de um compromisso equitativo entre as três vertentes do desenvolvimento sustentável - ambiental, econômico e social. Recentemente tem surgido desenvolvimentos na pesquisa do ACV que pretende integrar esta abordagem tripartida, o que originou um novo e mais abrangente conceito denominado por Análise de Sustentabilidade de Ciclo de Vida (Life Cycle Sustainable Assessment - LCSA). Conforme a figura 3.4, esta abordagem tripartida de LCSA corresponde ao conjunto de três avaliações distintas: Análise Ambiental do Ciclo de Vida (Environmental Life Cycle Assessment - ELCA), Análise de Custo de 
Ciclo de Vida (LCC) e Análise Social do Ciclo de Vida (SLCA). O ELCA e o LCC baseia-se na família da norma ISO 14040, enquanto que a vertente social (Social Life Cycle Assessment - SLCA) baseia-se pela norma ISO 26000 (Social Responsibility Guidance Standard) (MIDÕES, 2012) (UNEP, 2012).$$
L C S A=E L C A+L C C+S L C A
$$

Figura 3.4: Novo conceito de análise de sustentabilidade do ciclo de vida

Em suma, o ELCA avalia os impactos ambientais causados pelos produtos e matérias-primas em toda a fase do ciclo de vida, nomeadamente, extração, transporte, produção, uso, reciclagem e disposição final. O LCC avalia os custos associados ao ciclo de vida do produto, contabilizando não só os custos imediatos da aquisição, mas também os custos reversíveis. Pois, contabiliza o retorno do investimento através, nomeadamente, da redução dos consumos do edifício. O SLCA representa talvez a maior novidade nesta nova metodologia, uma vez pretende englobar a vertente social, existindo já alguns estudos sobre a esta matéria. O aprofundamento desta metodologia que interrelacione as três vertentes da sustentabilidade, constitui um grande desafio, mas pode permitir uma resposta rigorosa às necessidades das sociedades atuais.

\subsection{Sistemas de Certificação da Sustentabilidade de Edifícios}

O objetivo da certificação da sustentabilidade de edifícios passa pela avaliação quantificável e compreensiva das características de sustentabilidade de um dado edifício/empreendimento, baseada num conjunto de critérios que podem potenciar a procura de soluções com melhor desempenho (FERREIRA et al., 2013).

A maior parte dos sistemas de certificação são baseados nos regulamentos e legislação local, em soluções construtivas convencionais e o peso de cada parâmetro e indicador na avaliação é predefinido de acordo com as realidades sociocultural, ambiental e económica do local (BRAGANÇA; MATEUS, 2004). 
Capítulo 3 - Metodologias de Apoio à Concepção e Certificação da Sustentabilidade de Edifícios

O primeiro método de avaliação deste género surgiu em na década de 1990 no Reino Unido por meio do sistema Building Research Establish Environmental Assessment Method (BREEAM). Porém o aumento do interesse progressivo levou ao desenvolvimento e implementação de novos sistemas em vários países (REIS, 2011).

Devido à crescente gravidade dos problemas ambientais, alguns destes sistemas de certificação tendem a atribuir uma maior importância a este fator, descurando um pouco os fatores social e econômico. Qualquer sistema de certificação deverá considerar a ideia de que todos os aspetos da sustentabilidade estão interrelacionados, de que o edifício interage com a envolvente e que qualquer construção deverá contribuir positivamente para a melhoria de toda a zona onde se insere.

Apesar de existirem diferentes sistemas de certificação de sustentabilidade em edifícios que permitem abordagens distintas, eles têm vários objetivos em comum, tais como:

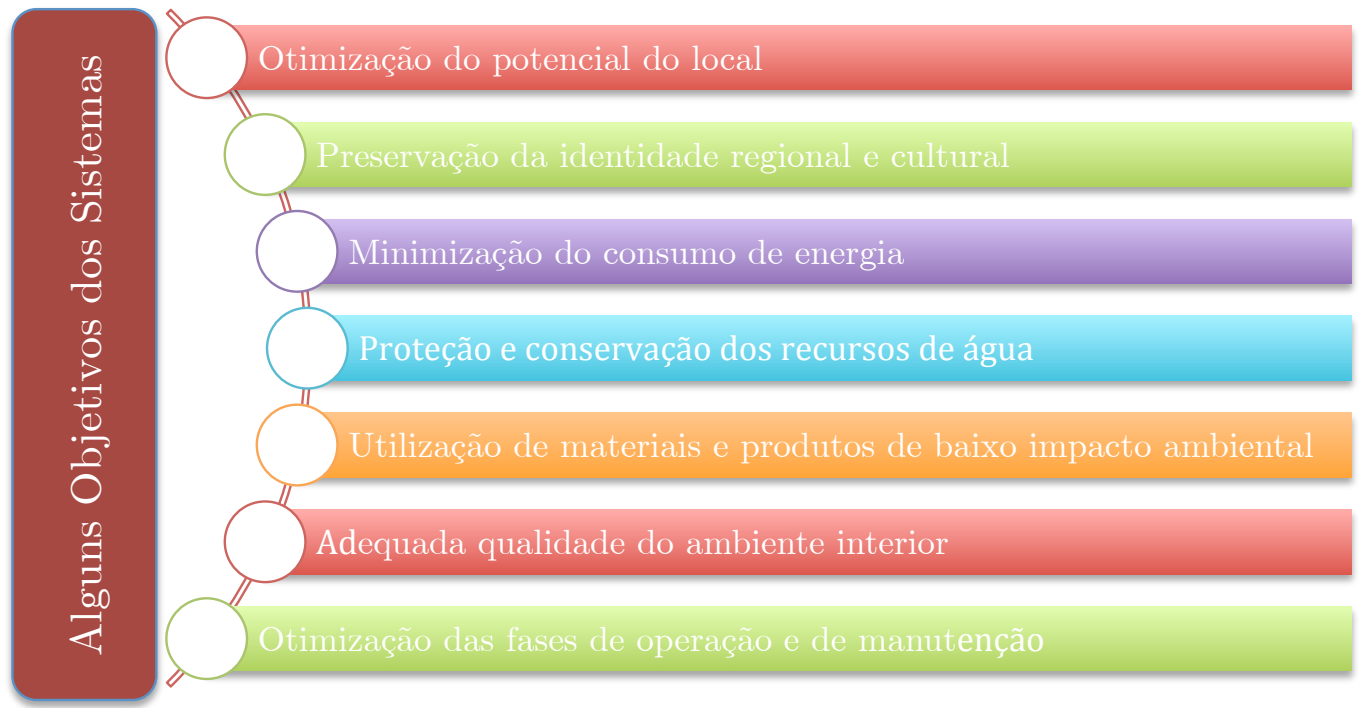

Figura 3.5: Alguns objetivos em comum dos sistemas de avaliação da sustentabilidade de edifícios (BRAGANÇA; MATEUS, 2004) (MIDÕES, 2012)

Ainda segundo Bragança e Mateus (BRAGANÇA; MATEUS, 2011): "As ligações entre o ciclo de vida dos edifícios e as três dimensões do desenvolvimento sustentável são inúmeras. O estudo integrado de todos esses critérios de avaliação, alguns quantitativos e outros puramente qualitativos, torna-se muito difícil se não for realizado através de um processo metódico." 
Conforme se referiu a maioria destes sistemas têm como finalidade a determinação do nível global de sustentabilidade de cada empreendimento, fornecendo uma dada classificação num ranking de pontuações, dependendo da mensuração técnica de certos valores matemáticos. A obtenção desse ranking recorre a ponderações próprias de cada sistema. Deste modo, trata-se de um conjunto de pesos que devem atender a vários fatores específicos de cada local/região geográfica, cuidadosamente elaborados e de forma a fomentar a introdução de uma filosofia de sustentabilidade, assente nas estratégias mais eficientes (FERREIRA et al., 2013).

Por outro lado, os principais responsáveis no setor imobiliário são geralmente promotores, investidores e gestores que pretendem maximizar os benefícios (por exemplo, o lucro), para os quais a comunicação da sua aposta numa construção sustentável é, em última instancia, um fator de valorização do imóvel, procurando a diferenciação no mercado. Neste sentido, a comunicação dos resultados a um público abrangente e aos potenciais compradores é muito importante e decisiva. Por isso, as ferramentas de avaliação da sustentabilidade na construção têm um papel decisivo para a procura da sustentabilidade, não só pela facilidade de interpretação de resultados que estas ferramentas permitem, mas também pela escala de representação do desempenho do edifício através diferentes classes hierárquicas e compreensíveis (FERREIRA et al., 2013). Segundo Ding (2008), este tipo de sistemas reflete o conceito de "sustentabilidade" no projeto e posteriormente no local da construção, fornecendo orientações fundamentais para que a construção evolua na proteção do meio ambiente e que possa atingir as metas definidas pelo desenvolvimento sustentável no contexto da construção.

Em antagonismo com este ponto de vista, vários autores associam uma falsa imagem ecológica dos sistemas de sustentabilidade e que os mesmos procuram unicamente o consumo e marketing de determinados produtos. Segundo John e Agopyan (2012): "Os selo são elitistas e, por consequência, isolados e não conseguem escala para soluções que minimizem o impacto ambiental médio do setor."

Estas diferentes opiniões, mais uma vez, está relacionada com a subjetividade associada ao conceito "sustentável" motivada principalmente pelas diferenças políticas, tecnológicas, culturais, sociais e económicas, existentes não só entre países, mas também, dentro de cada país, entre cada região. Especial cuidado deve ser tido sobre esta situação no sentido de não utilizar uma metodologia de avaliação de sustentabilidade fora do país/região onde foi desenvolvida sem que se realize 
previamente uma adaptação à realidade ambiental, social e económica do local onde se pretende realizar a avaliação.

Segundo o web-site Ecolabel Index (http://www.ecolabelindex.com), é possível constatar a existência de vários tipos sistemas (459 tipo de sistemas de 197 países e várias indústrias), cada um com as suas valências distintas, que tem de ser levadas em conta, quando se procede à escolha de um sistema de certificação de sustentabilidade. De salientar ainda, que os sistemas estão em constante evolução, para que sejam corrigidas eventuais limitações que tenham sido verificadas, em função das valências social, econômica e ambiental dos países onde são desenvolvidos. Por outro lado, apesar de existir um elevado número de sistemas de certificação, a estrutura é semelhante entre eles para os sistemas da construção civil (ZUO; ZHAO, 2013).

\subsubsection{Tipos de Ponderação e Especificidades dos Sistemas}

Conforme se referiu anteriormente, os objetivos dos sistemas de avaliação de sustentabilidade passam por fornecer uma classificação com base num ranking de pontuações. Por conseguinte, a obtenção deste ranking recorre a ponderações próprias de cada sistemas. Trata-se assim de conjunto de pesos que devem atender a vários fatores específicos de cada local/região geográfica, cuidadosamente elaborados de forma a fomentar a introdução de uma filosofia de sustentabilidade, assente nas estratégias mais eficientes (FERREIRA et al., 2013). Esta situação justifica as diferenças encontradas, quando se compararam os pesos atribuídos a um mesmo parâmetro em sistemas de avaliação distinto.

A maioria dos sistemas destina-se à utilização no país de origem, uma vez que foram concebidos com base nas práticas e condições existentes nessa região, sedo por isso limitada a sua perspectiva de adaptabilidade a outros locais com realidades económicas, sociais e ambientais diferentes (por exemplo o sistema brasileiro AQUA foi adaptado do sistema francês HQE; o sistema australiano NABERS foi adaptado do sistema americano LEED). Com efeito, a elaboração de sistemas, com base em sistemas de outros países, deve ser realizada de forma rigorosa, pois corre-se o risco de os sistemas de avaliação serem homogeneizados e perderem a sensibilidade ainda que haja vantagens óbvias na partilha de conhecimentos. Torna-se importante 
conhecer ao detalhe cada sistema e definir quais as suas características que podem ser utilizadas em cada caso e em cada realidade nacional (PINHEIRO, 2006).

Neste sentido, a escolha da ponderação é um dos procedimentos fundamentais em qualquer sistema, que implica sempre algum nível de subjetividade, uma vez que a opção por diferentes conjuntos de pesos pode ter influência no resultado pretendido. Não existe ainda consenso sobre a melhor forma de obter as ponderações, no entanto a maioria dos sistemas existentes opta pela criação de um painel, mais ou menos representativo dos vários especialistas, stakeholders, entre outros agentes relevantes, procedendo à realização de inquéritos no sentido de perceber qual a valorização média diferenciada que cada um atribui a cada critério (FERREIRA et al., 2013). Por este motivo existe sempre um certo grau de subjetividade associado a cada sistema, uma vez que os diferentes intervenientes valorizam diferentes aspectos e critérios da sustentabilidade. No entanto, se se aumentar a amostra e a representatividade da mesma, é possível balizar qual a importância média que os diferentes intervenientes dão a cada aspecto mas, mais uma vez, não se elimina completamente a subjetividade (PINHEIRO, 2006).

Por esta razão, a elaboração desta ponderação deve ser concretizada de forma muito cuidada e rigorosa para que, na prática, concretizem as realidades ambientais, sociais e econômicas de cada país/região geográfica, bem como as principais e prioridades assumidas a nível governamental permitindo assim que o sistema possa fomentar as estratégias mais eficientes e adequadas ao contexto onde se insere.

As primeiras metodologias de avaliação da sustentabilidade encontravam-se sobretudo orientadas para a dimensão ambiental e algumas delas tem evoluído nos últimos tempos no sentido de incorporarem critérios relacionados com as dimensões social e econômica (MATEUS, 2009).

Após este breve explicação, apresenta-se no subcapítulo seguinte, de forma detalhada, o sistemas de certificação da sustentabilidade dos edifícios AQUA e LEED, dado que são dois dos sistemas mais utilizados no Brasil. 


\subsubsection{Sistema de Certificação de Sustentabilidade AQUA}

O referencial técnico do processo AQUA (Alta Qualidade Ambiental) resulta de uma adequação ao contexto brasileiro do modelo francês Haute Qualité Environmentale (HQE). Foi elaborado através de um convênio de cooperação com a Fundação Vanzolini, em 2007. A Alta Qualidade Ambiental é definida como sendo um processo de gestão de projeto visando obter a qualidade ambiental de um empreendimento novo ou envolvendo a reabilitação. Refere-se ainda que este sistema foi o primeiro a ser desenvolvido para o contexto brasileiro.

O Processo AQUA estrutura-se em dois instrumentos principais: o Sistema de Gestão do Empreendimento (SGE) e o referencial de Qualidade Ambiental do Edifício (QAE). O referencial SGE avalia o sistema de gestão ambiental implementado pelo empreendedor; o referencial QAE avalia o desempenho arquitectónico e técnico da construção (AQUA, 2013).

Uma característica do SGE é permitir o planejamento, a operacionalização e o controle de todas as etapas de seu desenvolvimento, partindo do comprometimento com um padrão de desempenho definido e traduzido na forma de um perfil de Qualidade Ambiental do Edifício (QAE). O referencial SGE, apresenta um conjunto de exigências necessárias ao bom funcionamento de gestão para cada uma das fases do empreendimento, organizando-se da seguinte forma (AQUA, 2013):

- Comprometimento do empreendedor, onde são descritos os elementos de analise solicitados para a definição do perfil ambiental do empreendimento;

- Implementação e funcionamento, onde são descritas as exigências em termos de organização;

- Gestão do Empreendimento, onde são descritas as exigências em termos de monitoramento e analises criticas dos processos, de avaliação QAE;

- Aprendizagem, onde são descritas as exigências em termos de aprendizagem da experiência e de balanço do empreendimento.

Refere-se que é da responsabilidade do Promotor do empreendimento definir as competências, métodos, meios e documentação necessária para o atingimento dos objectivos e exigências necessárias. 
Na metodologia AQUA verificam-se 14 categorias, ou conjunto de preocupações, que são agrupadas de acordo com a tabela 3.2. Estas 14 categorias são desmembradas em subcategorias, representando as principais preocupações associadas a cada desafio ambiental. As fases analisadas são a do programa de necessidades, a de projeto e a de construção (GRUNBERG et al., 2014).

Para o empreendimento obter a certificação, num primeiro momento, é necessário que o Promotor do empreendimento faça contato com a Fundação Vanzolini adequando o edifício a um dos referenciais de certificação AQUA, tais como para edifícios residenciais, edifícios não residenciais, entre outros (Fundação Vanzolini, 2015). O processo de certificação ocorre por meio de auditorias presenciais seguidas de analise técnica. Atendidos os critérios de cada fase, programa, concepção e construção, procedendo-se à emissão dos respectivos certificados. Em cada uma destas fases o auditor, devidamente acreditado, verifica a implementação do SGE e verifica o atendimento aos requisitos de desempenho exigidos no referencial técnico QAE adoptado para o empreendimento.

$\mathrm{Na}$ etapa seguinte, já na fase de programa preliminar, o Promotor do empreendimento define o perfil de desempenho que pretende atingir na edificação com base nas 14 categorias QAE (tabela 3.2). Deve ainda ser assumido o compromisso e assegurar os recursos para obter o perfil programado, inclusive estabelecendo o SGE para assegurar o controle do projeto, até conclusão da obra.

$\mathrm{Na}$ fase de desenvolvimento de projeto, a equipa projetista utiliza o perfil de desempenho programado nas 14 categorias como elementos de entrada para o projeto. Neste caso, deve ser analisado globalmente cada fase de projeto e ao mesmo tempo, ser coerente com a anterior, bem como os objetivos iniciais definidos pelo Promotor do empreendimento.

A fase de construção deve estar alinhada com as indicações pertinentes de acordo com o perfil QAE e corrigir eventuais desvios que se afigurem necessários. 
Capítulo 3 - Metodologias de Apoio à Concepção e Certificação da Sustentabilidade de Edifícios

\begin{tabular}{|l|l} 
& \multicolumn{1}{c}{ Categorias Processo A QUA } \\
\hline Sitio e & Relação do edifício com o entorno \\
Escolha integrada de produtos, sistemas e processos \\
Canteiro de obra com baixo impacto ambiental \\
\hline Gestão da energia \\
Gestão da água \\
\hline Gestão dos resíduos de uso e ocupação do edifício \\
\hline Manutenção - permanência do desempenho ambiental \\
\hline Conforto higrotérmico \\
Conforto acústico \\
\hline Conforto visual \\
Conforto olfativo \\
\hline Qualidade sanitária dos ambientes \\
Qualidade sanitária do ar \\
\hline Qualidade sanitária da água \\
\hline Saúde
\end{tabular}

Tabela 3.2: Categorias do Processo AQUA (AQUA, 2013)

Os níveis de desempenho que uma edificação pode obter pelo processo AQUA são relacionados à Qualidade Ambiental do Edifício. O desempenho associado é expresso em três níveis:

- Bom: Corresponde ao nível desempenho mínimo aceitável para um empreendimento de Alta Qualidade Ambiental;

- Superior: Corresponde ao nível das boas práticas;

- Excelente: Corresponde ao nível de desempenho máximo constatados em empreendimentos de Alta Qualidade Ambiental.

A avaliação do empreendimento ocorre de maneira evolutiva composta por categorias, subcategorias e preocupações, as quais se avaliam pelos conceitos de Bom, Superior ou Excelente.

A atribuição do certificado está vinculada à obtenção de um perfil mínimo referentes às 14 categorias, conforme figura 3.6. 
Capítulo 3 - Metodologias de Apoio à Concepção e Certificação da Sustentabilidade de Edifícios

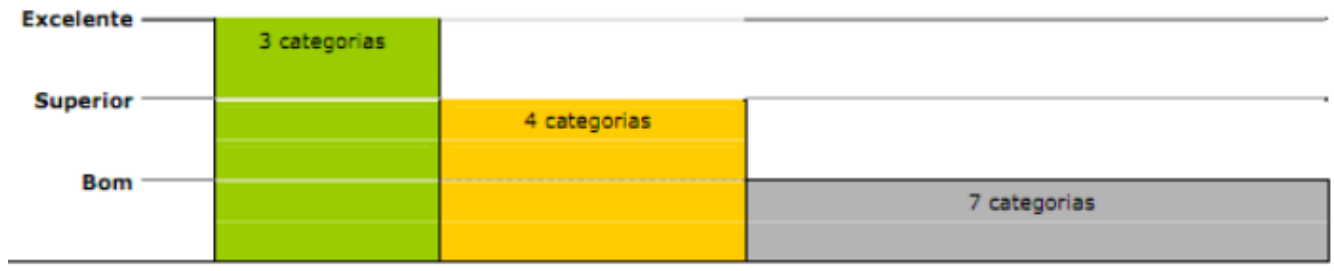

Figura 3.6: Exigência mínima para certificação no Processo AQUA (AQUA, 2013)

No subcapítulo seguinte irá ser analisado o sistema LEED, com destaque para a versão New Constructions and Major Renovations v3.0 e v4.0, pelo facto de corresponder à o versão que integra a Ferramenta que este trabalho desenvolveu.

\subsubsection{Sistema de Certificação da Sustentabilidade LEED}

Nos EUA, a organização United States Green Building Council (USGBC), financiada pelo National Institute of Standards and Technology (NIST), esteve na origem do sistema Leadership in Energy and Environmental Design (LEED)

Em 1998, após aprovação pelos membros do USGBC, surgiu a primeira versão LEED (v1.0). Esta versão mostrou-se limitada face aquilo que era esperado, uma vez que os quarenta créditos disponíveis, ou eram muito exigentes para serem atingidos, ou já eram prática corrente.

Estas limitações conduziram ao desenvolvimento de uma nova versão LEED (v2.0), que acabou por surgir em Março de 2000. Esta versão alargou o número de créditos para sessenta e nove. Com a crescente procura do sistema de certificação LEED, o USGBC lançou, no início de 2003, a versão (v2.1).

Em 2006 saiu para o mercado a versão 3.0, sendo atualizada em 2009 e 2011. Esta última versão é destinada para edifícios que se localizem fora dos EUA e ocasionou como novidade, um conjunto de requisitos alternativos, para demonstrar conformidade com os créditos. Deste modo permitiu a desvinculação das normas americanas ASHRAE, aceitando normas exteriores, tais como as normas da família CEN (Comité Europeu de Normalização).

Em Dezembro de 2013, a organização USBGC lançou para o mercado a mais recente versão LEED (v4.0). Atualmente a implantação desta versão no Brasil, só será obrigatória a partir do final de 2016. Até lá a versão 3.0 estará em vigência. 
Capítulo 3 - Metodologias de Apoio à Concepção e Certificação da Sustentabilidade de Edifícios

Atualmente, e conforme se pode observar na tabela 3.3, existem disponíveis um conjunto de versões LEED destinadas a diferentes utilizações.

\begin{tabular}{|c|c|}
\hline Versão & Utilizações \\
\hline $\begin{array}{l}\text { New Construction and } \\
\text { Major Renovation } \\
\text { (LEED-NC) }\end{array}$ & $\begin{array}{l}\text { Novas Construções comerciais e projetos de renovação com alguma } \\
\text { dimensão. Incluem-se edifícios de escritórios, edifícios altos } \\
\text { residenciais, fabricas, laboratórios e instalações recreativas }\end{array}$ \\
\hline $\begin{array}{l}\text { Existing Buildings } \\
\quad \text { (LEED-EB) }\end{array}$ & $\begin{array}{l}\text { Suportar operações e manutenção sustentável de edifícios existentes, } \\
\text { com o objetivo de maximizar a eficiência operacional minimizando o } \\
\text { impacto ambiental. Incluem-se programas de reciclagem, programas } \\
\text { de manutenção exterior e atualizações de sistemas }\end{array}$ \\
\hline $\begin{array}{l}\text { Commercial Interiors } \\
\quad(\text { LEED-CI })\end{array}$ & $\begin{array}{l}\text { Espaços comerciais interiores, com o objetivo de criar espaços } \\
\text { verdes, saudáveis e mais produtivos }\end{array}$ \\
\hline $\begin{array}{l}\text { Core and Shell } \\
\text { Development (LEED- } \\
\text { CS) }\end{array}$ & $\begin{array}{l}\text { Abrange a construção de elementos base da construção, tais como a } \\
\text { estrutura, sistemas do edifício, etc. Este sistema foi desenvolvido } \\
\text { para ser um complemento do LEED-CI. }\end{array}$ \\
\hline Home (LEED-H) & $\begin{array}{l}\text { Promove a construção e concepção de habitações de alto } \\
\text { desempenho energético e ambiental. }\end{array}$ \\
\hline $\begin{array}{l}\text { Neighbourhood } \\
\text { Development (LEED- } \\
\text { ND) }\end{array}$ & Vocacionado para o desenvolvimento envolvente. \\
\hline Schools (LEED-SCH) & $\begin{array}{l}\text { Vocacionado para a construção de escolas. Este sistema aborda a } \\
\text { singularidade dos espaços escolares e questões de saúde infantil. }\end{array}$ \\
\hline LEED-Retail & $\begin{array}{l}\text { Foi desenvolvido com base nos sistemas LEED-NC e LEED-CI e é } \\
\text { aplicado para projetos de comércio e serviços, tais como } \\
\text { restaurantes, bancos, vestuário, eletrônica, etc. }\end{array}$ \\
\hline
\end{tabular}

Tabela 3.3: Conjunto de versões LEED em função do tipo de utilização

Das várias versões disponíveis opta-se por descrever na especialidade o LEED- NC, atendendo a que foi essa versão que serviu de base à ferramenta proposta nesta dissertação. Na realidade, optou-se por esta versão uma vez que é uma das mais utilizadas, considerando a sua abrangência que pode ser adaptada a diferentes contextos, tais como edifícios de habitação de múltiplos pavimentos e edifícios de serviços. No capítulo 5 será devidamente justificado os motivos e pertinência da utilização desta versão.

Com efeito, o sistema LEED-NC v3.0 avalia o edifício em sete áreas chaves que, por sua vez, dividem-se num conjunto de subitens específicos e pontuáveis. Neste processo de certificação é necessário cumprir um conjunto de pré-requisitos de desempenho, de carácter obrigatório. As sete áreas gerais a serem avaliadas, são:

- Locais sustentáveis (sustainable sites); 
- Eficiência hídrica (water efficiency);

- Energia e atmosfera (energy \& atmosphere);

- Materiais e recursos (materials \& resources);

- Qualidade do ambiente interior (indoor environmental quality);

- Inovação no projeto (innovation in design);

- Prioridade regional (regional priority).

Salienta-se que a área a avaliar, denominada de prioridade regional, só está disponível para construções desenvolvidas nos EUA. Esta área possui um peso reduzido em relação às outras, e tem como objetivo valorizar um determinado empreendimento em função do local onde vai ser construído, de acordo com o fim a que se destina. Relativamente ao peso de cada área, o LEED-NC v3.0 estabelece da seguinte forma:

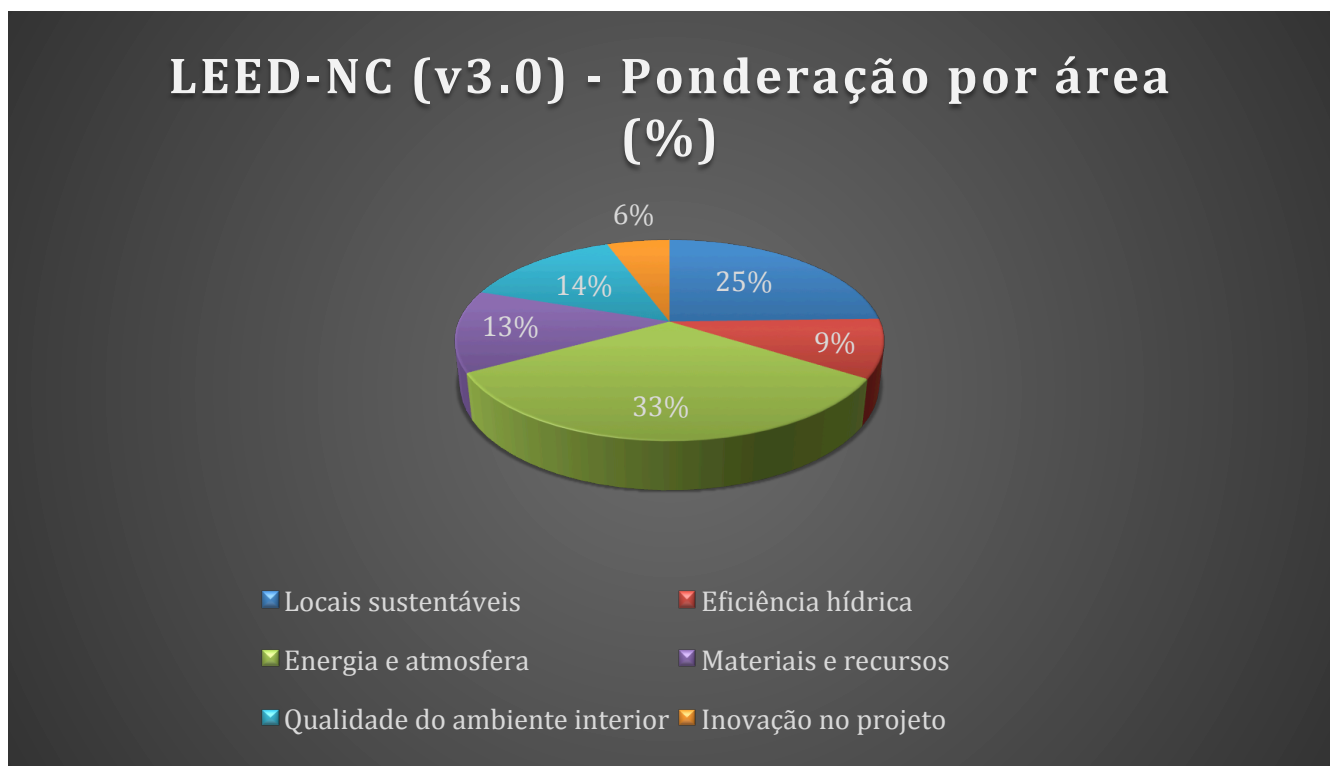

Figura 3.7: Ponderação (em percentagem) por área do sistema LEED-NC v3.0 (LEED, 2011)

Tal como referido anteriormente, o peso atribuído a cada uma das categorias é predefinido de acordo com as realidades sociocultural, ambiental e económica do local. Cada uma das áreas gerais encontra-se dividida em subitens e pré-requisitos. Cada subitem é contabilizado com um ou mais pontos, e os pré-requisitos são de cumprimento obrigatório.

Atendendo à disparidade de consumo energético residencial entre os EUA e o Brasil, os $33 \%$ atribuídos à categoria Energia e Atmosfera aparentam ser largamente desajustados. Na realidade, e conforme enunciado no capítulo 2, a Matriz energética 
de renováveis brasileira é uma das mais limpas do mundo, para além que o consumo per capita de energia residencial é igualmente baixo quando comparado com os EUA, aproximadamente oito vezes inferior.

O Anexo 1 demonstra quais os critérios aplicáveis e respetivos pontos associados a cada uma das áreas avaliadas pelo LEED-NC v3.0.

A certificação LEED atribuída ao edifício corresponde à soma direta dos critérios cumpridos, sem prejuízo do cumprimento obrigatório dos pré-requisitos específicos em cada área. Estão disponíveis cem pontos de base que correspondem às cinco categorias principais, seis pontos relativos à inovação no projeto e quatro pontos para prioridade regional (caso o edifício se localize nos E.U.A.).

No entanto, para que a certificação LEED seja atribuída, é necessário atingir um mínimo de 40 pontos. Para valores superiores, temos os seguintes escalões de certificação:

\begin{tabular}{|c|c|}
\hline Níveis de Classificação & Pontos \\
\hline LEED Certificado & $40-49$ \\
\hline LEED Prata (Silver) & $50-59$ \\
\hline LEED Ouro (Gold) & $60-79$ \\
\hline LEED Platina (Platinum) & $>=80$ \\
\hline
\end{tabular}

Tabela 3.4: Níveis de classificação segundo a versão LEED-NC (LEED, 2011)

Procede-se agora a uma análise da última versão LEED, corresponde à versão 4.0, apesar de não apresentar diferenças significativas da versão 3.0. existem algumas alterações e ajustes efetuados, destacando-se as seguintes diferenças:

- A vertente de Locais sustentáveis da versão 3.0 foi subdividida em duas, nomeadamente Localização e Transporte e Locais Sustentáveis para a versão 4.0. De acordo com a tabela 3.5 é possível constatar este desmembramento, bem como a divisão dos pontos associados a cada uma;

- Foram revistos e atualizados alguns créditos, a versão 4.0 apresenta algumas novidades, por exemplo na vertente de Materiais aparecem as Declarações Ambientais de Produtos (DAP), na vertente IEQ aparece desempenho acústico do edifício, entre outras. No entanto a maioria dos indicadores da 
Capítulo 3 - Metodologias de Apoio à Concepção e Certificação da Sustentabilidade de Edifícios

versão 3.0 manteve-se, existindo apenas uma atualização ao nível da informação técnica que compõe o referencial;

- Alguns créditos sofreram um ajuste relativamente aos número de pontos que que estavam associados aos mesmos. De forma análoga houve também um ajuste em alguns pré-requisitos.

- O LEED v4.0 prevê um crédito adicional caso o projeto seja desenvolvido de forma integrada. Conforme irá ser devidamente detalhado no próximo capítulo (Gestão de Projetos), o processo de concepção integrado é a maneira mais eficiente de alcançar os objetivos da construção sustentável.

No Anexo 1 encontram-se detalhados os critérios aplicáveis e respetivos pontos associados a cada uma das áreas avaliadas pelo LEED-NC v4.0. A figura 3.8 estabelece o peso de cada área desta última versão.

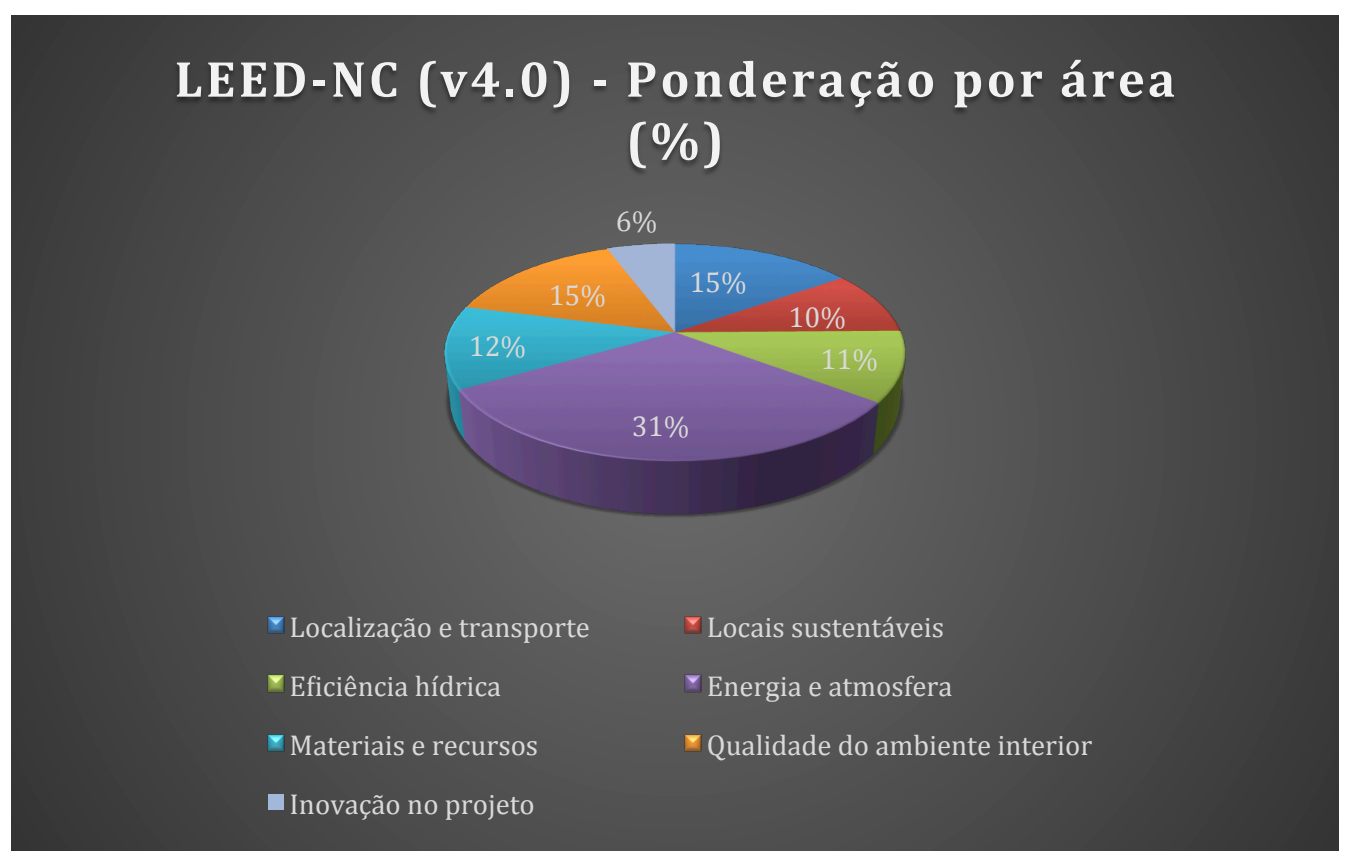

Figura 3.8: Ponderação (em percentagem) por área do sistema LEED-NC v4.0

A tabela 3.5 elucida as diferenças entre as duas versões do LEED, no que se refere aos pontos associados para cada área de avaliação. 
Capítulo 3 - Metodologias de Apoio à Concepção e Certificação da Sustentabilidade de Edifícios

\begin{tabular}{|l|c|c|c|c|}
\cline { 2 - 5 } \multicolumn{1}{c|}{} & \multicolumn{2}{c|}{ LEED NC v4.0 } & \multicolumn{2}{c|}{ LEED NC v3.0 } \\
\hline Áreas avaliadas & Pontos & $\begin{array}{c}\text { Peso ponderado } \\
\text { (\% de pontos) }\end{array}$ & Pontos & $\begin{array}{c}\text { Peso ponderado } \\
\text { (\% de pontos) }\end{array}$ \\
\hline Localização e transporte & 16 & $15 \%$ & & 26 \\
\hline Locais sustentáveis & 10 & $10 \%$ & 10 & $9 \%$ \\
\hline Eficiência hídrica & 11 & $10 \%$ & 35 & $33 \%$ \\
\hline Energia e atmosfera & 33 & $31 \%$ & 14 & $13 \%$ \\
\hline Materiais e recursos & 13 & $12 \%$ & 15 & $14 \%$ \\
\hline $\begin{array}{l}\text { Qualidade do ambiente } \\
\text { interior }\end{array}$ & 16 & $15 \%$ & 6 & $6 \%$ \\
\hline Inovação no projeto & 6 & $6 \%$ & 106 & $100 \%$ \\
\hline
\end{tabular}

Tabela 3.5: Diferenças entre a versão 3.0 e 4.0 do LEED-NC

Em termos gerais, o sistema LEED apresenta as seguintes particularidades:

- O peso de cada parâmetro e indicador na avaliação da sustentabilidade do edifício são pré-definidos, e consequentemente, não podem ser alterados e ajustados em função das realidades sociocultural, ambiental e económica do local;

- Para edifícios localizados fora dos EUA, o LEED prevê um conjunto de opções alternativas para se verificar alguns indicadores de sustentabilidade. Os projetos não tem necessariamente de ser elaborados com base nas normas ASHRAE;

- Permite aos projetistas e aos intervenientes envolvidos no processo da construção, muita informação técnica para aplicar o sistema, facilitando a implementação de medidas sem necessariamente ter de proceder à certificação.

Refere-se ainda que o sistema LEED apresenta alguns créditos que se aproxima do conceito ACV, no entanto sem o carácter holístico, uma vez que observa essas características de forma isolada. Ao nível da versão 3.0 do LEED, tais créditos estão diretamente ligados com a escolha dos componentes construtivos que incluem por exemplo o reuso e reciclagem de materiais, utilização de materiais de fontes renováveis, materiais recuperados e produtos com baixas emissões de GEE (BUENO, 2014). A versão 4.0 acrescenta as DAP, promovendo a utilização produtos e materiais de construção que apresentem baixos impactos ambientais considerando o ciclo de vida dos mesmos. 


\section{CAPÍTULO 4 - GESTÃO DE PROJETOS}

\subsection{Conceitos Gerais}

Este subcapítulo pretende fazer uma revisão bibliográfica com enfoque em alguns conceitos fundamentais no âmbito da gestão de projetos.

\subsubsection{Definição de Projeto}

A palavra projeto tem diferentes significados para diferentes pessoas e nenhuma definição de projeto se adequa a toda e qualquer situação. Segundo o Project Management Institute (PMI), um projeto é um compromisso temporário delineado para criar um produto, serviço ou resultado único (PMBOK, 2013). A natureza temporária significa que todos os projetos têm um início e fim bem definidos. O projeto termina quando os objetivos forem alcançados, quando se torna claro que estes não podem ser alcançados, ou quando já não existe a necessidade de o projeto existir e, em todo o caso, a sua duração é finita. Os projetos pretendem criar algo que ainda não foi feito, ou seja, único. No entanto, um produto ou serviço pode ser único mesmo que sua concepção seja algo comum e que haja uma repetição de elementos.

O projeto também pode ser entendido como produto e como processo. O projeto como produto traduz requisitos dos clientes em representações gráficas e especificações técnicas que apresentam informações qualificadas e propiciam uma antevisão do produto. O projeto como processo compreende as atividades distintas e coordenadas ao longo do seu desenvolvimento, englobando a concepção, planeamento dos métodos e técnicas construtivas e a execução da obra (FABRÍCIO, 2002) (ANDERY et al., 2012).

Segundo John F. Woodward (1998), todos os projetos têm algumas características em comum, tais como:

- Objetivo quantificável num produto final, resultado ou serviço, definido em termos de custo, qualidade e tempo;

- Natureza temporária, com uma data de início e de fim bem definidos;

- Unicidade, isto é, o projeto ser único, não repetitivo;

- Complexidade relacionada com as várias atividades que têm de ser realizadas para se atingirem os objetivos. A relação entre um grande número de tarefas separadas e interdependentes pode ser muito complexa; 
- Incerteza, isto é, os projetos são planeados antes de serem executados, e por isso, tem associado um fator de risco: incerteza do tempo de realização;

- Ciclo de vida, que se refere às diferentes fases pelas quais passa um projeto ao longo do tempo, conforme será descrito mais à frente.

\subsubsection{Gestão de Projetos}

Ao longo das últimas décadas tem-se assistido a uma tendência crescente para as obras dos empreendimentos serem cada vez mais abrangentes, complexas e mecanizadas. Para além disto, as crescentes exigências da sociedade bem como a utilização de novos materiais e processos construtivos têm contribuído decisivamente para o desenvolvimento de especialidades técnicas, cada uma delas com níveis de detalhe cada vez mais minuciosos. Como consequência a gestão ou coordenação de projetos, torna-se cada vez mais importante para coordenar sistematicamente os profissionais do setor e respetivos projetos, de forma a atender ao mercado da construção civil, cada vez mais exigente.

Segundo o PMI "a gestão de projetos é a aplicação de metodologias, conhecimentos, técnicas e ferramentas ao conjunto de atividades que compõem um projeto, de forma a exceder as expectativas e necessidades dos stakeholders ${ }^{6}$, cumprindo indicadores fundamentais do projeto como o tempo, custo, qualidade e realização dos objetivos propostos" (PMBOK, 2013);

No âmbito da gestão de projetos, importa salientar a diferença que este termo pode significar quando analisado à luz da literatura inglesa. Com efeito, o termo design management pode ser entendido como as atividades de planeamento e concepção dos projetos, incluindo os assuntos relacionados com a coordenação entre arquitetura e as várias especialidades da engenharia; por outro lado o termo project management está relacionado com a gestão do empreendimento, conforme difundido, por exemplo, nos textos do PMI.

Para Melhado (2005) a gestão de projetos compreende o conjunto de ações envolvidas no planeamento, organização, direção e controle das atividades que compõem um projeto envolvendo a definição do programa, definição de características do produto a ser construído, a formação e condução das equipa de projeto em cada

\footnotetext{
${ }^{6}$ A definição de stakeholder em português significa parte interessada (acionistas, promotores, investidores, etc.)
} 
empreendimento, bem como o estabelecimento de prazos para etapas de projeto e coordenação da interface com os clientes finais.

Um bom projeto de execução é condição sine qua non para consecução de obras. Por conseguinte, um maior cuidado com a etapa de projeto repercute em ganhos e o investimento envolvido é relativamente modesto comparado aos ganhos com modificações no decorrer das obras (ANDERY et al., 2012).

De acordo com Fabrício, a coordenação de projetos exige a articulação e o questionamento das especialidades de projeto em benefício do todo. Nessa tarefa, o papel do coordenador demanda um amplo conhecimento multidisciplinar (incluindo produto e processo) e uma capacidade de gerir o processo e de integrar os profissionais das equipas de projeto e seus trabalhos. Ainda segundo o mesmo autor, as decisões tomadas durante o desenvolvimento dos projetos, em geral, não consideram as particularidades da produção das edificações, não contribuindo, desta forma, para a melhoria da eficiência das suas atividades (FABRÍCIO, 2002).

No caso de obras com riscos especiais frequentes durante a construção, deverão ter-se em conta aspetos de segurança na fase de execução, devendo o coordenador do projeto compatibilizar a sua ação com o coordenador de segurança em fase de projeto, quando este existir (PEREIRA, 2014).

\subsubsection{O Coordenador de Projetos}

O coordenador de projetos tem com principal atribuição realizar e fomentar ações de integração entre projetistas e coordenar e controlar os projetos e as trocas de informação, para garantir que o processo ocorra organizadamente e cumpra os prazos e objetivos estabelecidos.

Por outro lado, no decurso das várias fases de desenvolvimento de um projeto (abordado no próximo subcapítulo), o trabalho da equipa projetista desenvolve-se em múltiplas frentes geralmente separadas por especialidades. Esta separação pode afetar significativamente a qualidade dos projetos uma vez que existem condicionalismos e interdependências de várias ordens entre as especialidades envolvidas. De forma a conseguir uma maior articulação do trabalho que vai sendo realizado pelos vários autores de projeto, sobretudo em grandes empreendimentos, torna-se determinante existir a figura do coordenador de projeto. Segundo Pereira (2014), um dos maiores entreves à coordenação dos projetos reside na falta de troca de informação entre os 
diversos técnicos projetistas atuando, muitas vezes, de forma isolada e muitas vezes sem qualquer troca de informação com os restantes. A troca de informação que se afigura necessária não se deve processar unicamente na vertical, devendo ser partilhada numa ótica que envolva a sua transmissão na horizontal (entre especialidades). Na prática a solução passa muitas vezes pela realização de reuniões de coordenação entre os diversos técnicos. Deverá ainda existir um sistema que promova a gestão e troca de informação através da utilização da internet e de aplicações informáticas específicas.

Quanto ao perfil ideal da figura coordenador de projetos, Melhado (2005) refere que o mesmo deve possuir amplo conhecimento relativo às diversas especialidades de projeto, que conheça as técnicas construtivas e possua experiência quanto à execução de obras. Para além disto é igualmente importante que o coordenador de projetos tenha capacidade de liderança e de gestão de recursos humanos.

A prática profissional mostra que a necessidade de coordenação terá particular importância no caso de projetos de edifícios. Nele coexistem especialidades bastante diversificadas e com alto grau de conflitualidade, salientando-se a incompatibilidade espacial de vários elementos. Atualmente predominam dois modelos organizacionais de equipas que diferem segundo o papel e a posição do coordenador de projetos. De acordo com o primeiro modelo organizacional, a coordenação é uma atividade da responsabilidade do autor do projeto de arquitetura, uma vez que no projeto de edifícios praticamente toda a concepção, forma e organização espacial, é definida pela arquitetura. Deverá ser assim a especialidade que assumirá a coordenação de projeto, efetuando a síntese entre os aspetos contraditórios das várias vertentes presentes e assegurando a sua compatibilidade. Em um processo sequencial, este modelo tradicional é possivelmente o mais coerente, tendo em conta que a concepção do edifício é realizada de forma independente dos demais intervenientes. O segundo modelo organizacional, a coordenação do projeto é da responsabilidade de um elemento independente à equipa projetista e tem como objetivo coordenar a troca de informações e interações entre os vários intervenientes, de forma a criar uma coordenação especializada e focada exclusivamente nas tarefas e atribuições pertinentes à coordenação (FABRÍCIO, 2008). Ainda sobre este aspeto é importante mencionar que a norma brasileira (NBR 13531, 1995), no qual estabelece as diretrizes na elaboração de projetos de edificações, refere o seguinte: "A coordenação geral das atividades técnicas de projeto de edificação deve ser feita em função das determinações do projeto de arquitetura". Pela definição da norma se percebe que de 
acordo com a legislação brasileira a coordenação geral de projetos incide sobre o primeiro modelo organizacional - tradicional.

\subsection{Processo de Desenvolvimento de um Edifício/Empreendimento}

A realização de um empreendimento compreende genericamente por ordem cronológica, o estudo da sua viabilidade, a concepção e projeto, a adjudicação do contrato para a sua execução, a execução da obra e recepção, a utilização e manutenção (figura 4.1). No final do ciclo de vida surge ainda um conjunto de opções que incluem a reabilitação, a desconstrução ou a demolição (PEREIRA, 2014).

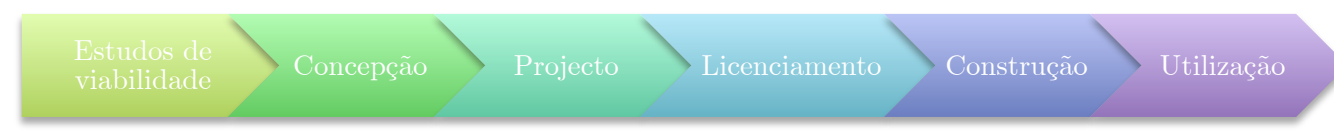

Figura 4.1: Faseamento genérico de um empreendimento, adaptado de (PEREIRA, 2014)

Tradicionalmente o faseamento temporal destas atividades desenvolve-se de uma forma sequencial e fragmentada, sendo que a atuação dos vários intervenientes ocorre de forma encadeada.

Por outro lado e no sentido de otimizar este processo, têm vindo a ser introduzidas algumas mudanças para romper o paradigma do modelo sequencial de desenvolvimento de um empreendimento e estimular uma visão abrangente e integrada do binómio projeto/produção, com vista a reduzir prazos e custos, aumentar a qualidade e a satisfação de todas as partes interessadas (ANDERY et al., 2012). Na realidade, os problemas que não tenham sido resolvidos na fase de concepção e projeto vêm em regra a revelar-se durante a execução, com maior impacto financeiro, atrasos no prazo de conclusão ou até repercussões na qualidade do produto final.

Uma das propostas de mudança de filosofia presente na literatura é o conceito Desenvolvimento Integrado do Empreendimento $\left(\mathrm{IPD}^{7}\right)$, por meio do qual envolve a criação de uma equipa de projeto com uma maior gama de técnicos especialistas, decisores locais e outros parceiros, do que o processo de concepção tradicional, incluindo elementos com experiência nas fases de construção, operação, manutenção e outros que estabeleçam o canal de ligação com a comunidade local (AIA, 2008). A

7 Acrónimo da expressão da língua inglesa "Integrated Project Delivery" 
relação entre estes intervenientes deverá desenvolver-se num ambiente totalmente colaborativo, partilhando abertamente a informação e conhecimento, sendo baseada nos princípios de confiança, partilha de risco e resultados (AIA, 2008). Este conceito permite antecipar o esforço do desenvolvimento do empreendimento para as fases iniciais por meio de uma maior sobreposição das atividades, traduzindo-se numa economia de custo e tempo. A figura 4.2 apresenta a comparação do esforço de desenvolvimento do empreendimento ao longo do tempo, entre o processo tradicional e o processo IPD.

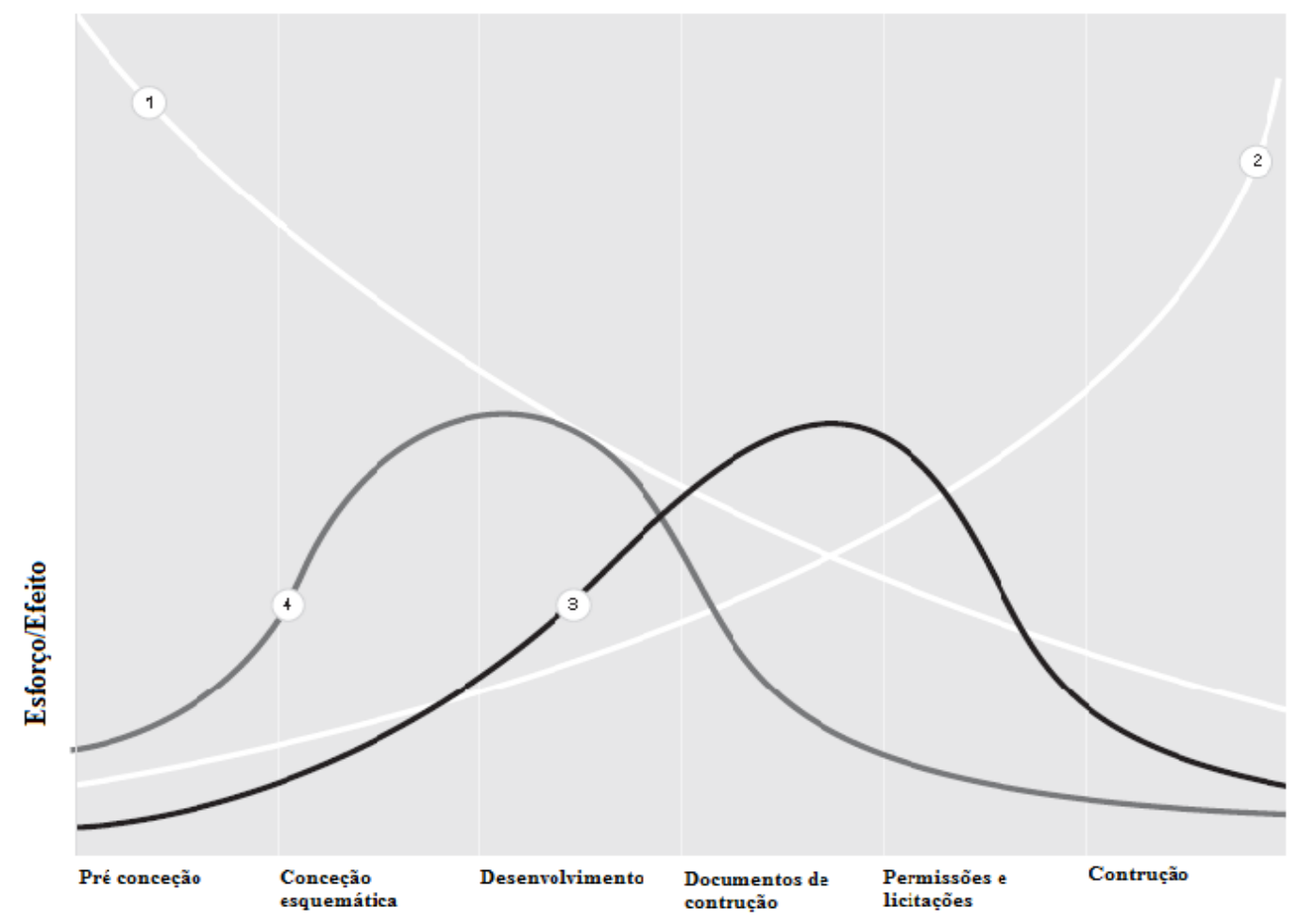

Figura 4.2: Fases de projeto em função do esforço efetuado, traduzido de (AIA, 2008)

As linhas de 1 a 4 ilustradas na imagem representam:

- Linha 1: Capacidade de influenciar os custos e as capacidades funcionais;

- Linha 2: Custos na mudança do projeto;

- Linha 3: Distribuição do esforço segundo o processo tradicional

- Linha 4: Distribuição do esforço segundo o processo integrado

Pela análise da figura 4.2 verifica-se uma clara diferença entre o processo tradicional e o processo integrado. Se por um lado o pico do esforço, segundo o processo tradicional, se encontrar numa fase mais a jusante, as mudanças no projeto tendem a 
originar custos acrescidos; por outro lado no processo integrado o pico do esforço se encontrar numa fase mais a montante as mudanças no projeto conduzem relativamente a custos mais baixos.

As curvas referentes ao esforço são obtidas a partir da comparação entre o processo tradicional de concepção-concurso-construção ${ }^{8}$ e o processo IPD. O American Institute of Architects of California Council (AIA CC) procedeu à análise dos principais momentos de desenvolvimento do empreendimento, referente ao que se deve construir (O Quê), como realizar (Como) e quem deve realizar as tarefas (Quem). Os objetivos chave do projeto são transferidos para montante do projeto obrigado a uma participação inicial dos vários intervenientes, conforme esquematizado na figura 4.3 (AIACC, 2014). Enquanto que na metodologia tradicional cada fase do desenvolvimento do empreendimento possuir uma relação de fim-início e desfasamento nulo com a fase sucessora. No IPD, as relações entre as fases continuam a ser do tipo fim-inicio, no entanto, admite-se que não é necessário a conclusão de todas as componentes do projeto para que se inicie a fase seguinte, permitindo a existência de sobreposição entre fases, originando um ganho de tempo e de valor no desenvolvimento do empreendimento.

${ }^{8}$ A metodologia concepção-concurso-construção, do inglês design-bid-build é uma das mais utilizadas. O cliente contrata um arquiteto para desenvolver um programa e de seguida realiza a concepção do projeto com auxílio dos engenheiros. Posteriormente existem propostas por parte de empreiteiros para licitar a obra e o escolhido constrói a obra. 

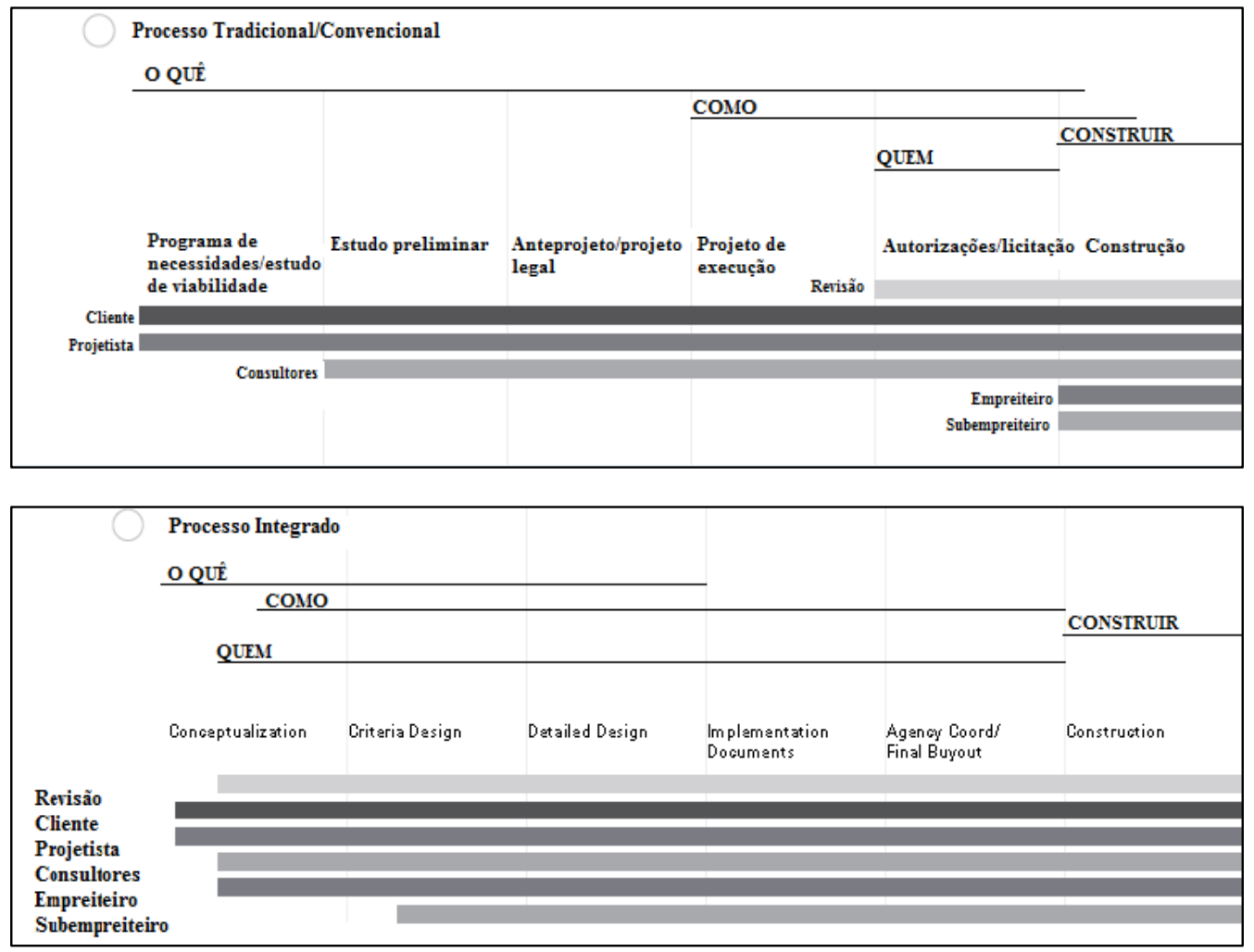

Figura 4.3: Fases de um processo tradicional e de um processo integrado, traduzido de (AIACC, 2014)

A tabela 4.1 representa um resumo da associação das diversas fases entre a metodologia tradicional e as de projeto integrado, assim como os documentos utilizados na definição das mesmas. 


\begin{tabular}{|c|c|c|c|}
\hline Fases da metodologia tradicional & Fonte & Fases do projeto integrado & Fonte \\
\hline Levantamento & NBR13.531/95 & - & - \\
\hline Programa de necessidades & NBR13.531/95 & \multirow{2}{*}{ Conceptualization } & Manual AIA \\
\hline Estudo de viabilidade & NBR13.531/95 & & Manual AIA \\
\hline Estudo preliminar & NBR13.531/95 & Criteria design & Manual AIA \\
\hline Anteprojeto & NBR13.531/95 & \multirow{2}{*}{ Detailed design } & Manual AIA \\
\hline Projeto legal & NBR13.531/95 & & Manual AIA \\
\hline Projeto para execução & NBR13.531/95 & Implementation documents & Manual AIA \\
\hline Licitação & Lei $8.666 / 93$ & Buyout & Manual AIA \\
\hline Construção & Lei 8.666/93 & Construção & Manual AIA \\
\hline Fecho de obra & Lei 8.666/93 & Fecho de obra & Manual AIA \\
\hline
\end{tabular}

Tabela 4.1: Associação com as fases de metodologia tradicional e as fases de projeto integrado

Ainda sobre esta temática de projeto integrado refere-se o trabalho de Fabrício (2002) na tese "Projeto Simultâneo na Construção de Edifícios". O autor define Projeto Simultâneo de edifícios como: "O desenvolvimento integrado das diferentes dimensões do empreendimento, envolvendo a formulação conjunta da operação imobiliária, do programa de necessidades, da concepção arquitetônica e tecnológica do edifício e do projeto para produção, realizado por meio da colaboração entre o agente promotor, a construtora e os projetistas, considerando as funções subempreiteiros e fornecedores de materiais, de forma a orientar o projeto à qualidade ao longo do ciclo de produção e uso do empreendimento". Por meio de atividades paralelas, o projeto simultâneo procura reduzir o tempo global do desenvolvimento do empreendimento e a diminuição dos problemas decorrentes do projeto, com uma maior iteração entre todos os agentes envolvidos no processo.

O conceito de projeto simultâneo envolve um fluxo de informação cabal entre os diversos intervenientes e uma gestão competente das interfaces do projeto, conforme ilustrado na figura 4.4 . 


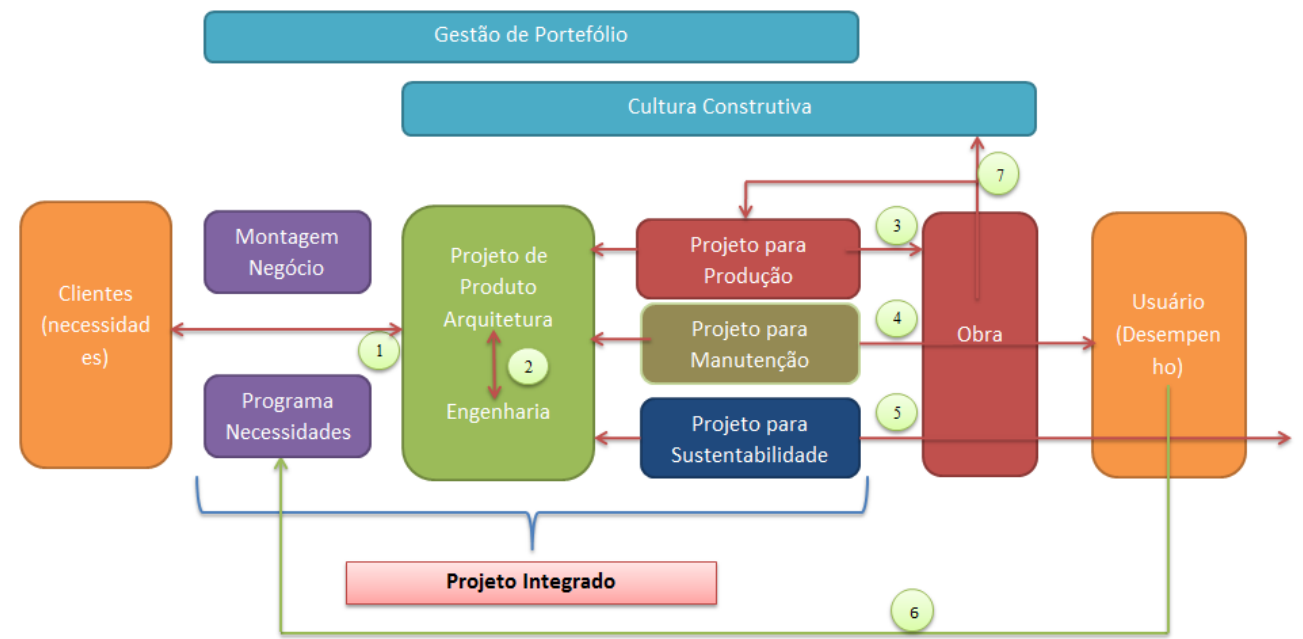

Figura 4.4: Interfaces do processo de desenvolvimento de um empreendimento, adaptado de (FABRÍCIO, 2013)

Interface 1: Ocorre entre os clientes e os requisitos do projeto e o projeto do produto. Deve ser adequado às necessidades e objetivos dos clientes. Uma das principais dificuldades desta interface é identificar os mercados e compreender quais são as necessidades do utilizador e a sua expressão em termos das funções que este deve desempenhar.

Interface 2: Ocorre entre os projetos de arquitetura, engenharia e complementares no qual devem ser compatíveis entre si. Esta interface relaciona a coordenação na atuação dos projetistas e no desenvolvimento das diferentes disciplinas de projeto. O projeto deve incorporar as necessidades e expectativas dos clientes, quer em termos funcionais, quer em termos técnicos. As características funcionais são aquelas que permitem dar resposta ao quadro das necessidades do utilizador (manutenibilidade, fiabilidade, comodidade, etc.). As características técnicas resultam da solução técnica adotada pelos projetistas (material, peso, altura, etc.).

Interface 3: Ocorre entre o projeto do produto e a obra - projeto para produção. O projeto do produto deve ser compatível com a cultura construtiva das empresas responsáveis pela obra. Segundo Fabrício (2002) "A efetiva implantação do Projeto Simultâneo é necessário que o desenvolvimento dos projetos para produção ocorra em sintonia e de forma concomitante ao desenvolvimento do produto de maneira a permitir a exploração conjunta das soluções espaciais e técnicas do produto com as possibilidades construtivas." 
Interface 4: Ocorre entre o projeto do produto e o uso e manutenção do edifício. O projeto do produto deve atender às exigências de desempenho do futuro usuário. Importa referir que o produto deve estar estritamente relacionado com o segmento de consumidores a satisfazer, ou seja, tem de não só possuir as características desempenho que os usuários esperam dele, mas também aquilo que estão dispostos a pagar. A solução deverá ser aquela que ao mínimo custo corresponda ao maior valor acrescentado para o usuário.

Interface 5: Entre o projeto do produto e o meio ambiente do edifício (sustentabilidade). O projeto do produto deve incluir requisitos de sustentabilidade segundo as três vertentes do desenvolvimento sustentável - ambiental, económica e social. A utilização de sistemas de certificação de sustentabilidade é uma das hipóteses para introduzir medidas e soluções de sustentabilidade no edifício. O presente trabalho que está sendo desenvolvido vai neste sentido, ou seja, pretende-se desenvolver um instrumento que permita auxiliar a gestão de projetos no âmbito da sustentabilidade dos edifícios residenciais.

As interfaces 6 e 7 dependem da utilização do edifício e execução da obra, respetivamente, sendo portanto atividades sequenciais à concepção do produto e devem retroalimentar o processo (FABRÍCIO, 2002).

Interface 6: Consiste no acompanhamento do empreendimento durante a fase de uso e manutenção no sentido de aferir os resultados alcançados e a satisfação dos clientes por meio de avaliações desempenho e pós ocupação, as quais tem por finalidade retroalimentar os processos de desenvolvimento de novos empreendimentos. Importa referir que apesar de ser importante medir a satisfação dos clientes em relação ao produto final, a qualidade não depende exclusivamente do produto físico. $\mathrm{Na}$ realidade, não existem produtos puros, o que existe, de fato, é sempre um misto de produto e serviço.

Interface 7: Consiste no acompanhamento da obra e elaboração do projeto como construído (as built) de forma a garantir a retroalimentação de projetos futuros e a manutenibilidade do edifício construído (FABRÍCIO, 2002).

De acordo com a literatura estudada, vários autores indicam que para introduzir no projeto soluções e medidas no âmbito da construção sustentável são necessárias mudanças substanciais no modo como se planeiam e concebem tradicionalmente as construções. Conforme evidenciado, as decisões tomadas na fase de projeto é condição 
fundamental uma vez que afetarão todas as fases do ciclo de vida de um edifício. Adicionalmente a multidisciplinaridade associada aos edifícios exige que os diversos agentes se reúnam desde o início do processo de realização do empreendimento de modo a que seja possível integrar os objetivos da construção sustentável nas diversas fases do desenvolvimento dos edifícios. Estes que estes aspetos são essenciais para que se atinjam níveis de sustentabilidade superiores à prática pelo que será devidamente abordado no próximo subcapítulo.

\subsection{A Importância do Projeto para a Construção Sustentável}

A importância de considerar a sustentabilidade logo no início do desenvolvimento do projeto atende à necessidade de encontrar soluções de longo prazo que garantam um equilíbrio entre as três dimensões do desenvolvimento sustentável (ambiental, social e económica). Vários autores reconhecem a importância da fase de projeto para se atingirem níveis elevados de sustentabilidade nos edifícios. Durante este estágio são definidos a maioria dos materiais e métodos de construção, bem como são determinadas as questões relacionadas com a funcionalidade e qualidade do edifício (REKOLA et al., 2012).

Segundo Son (2009), os aspetos da sustentabilidade devem estar presentes em todas as fases do desenvolvimento do empreendimento, começando logo na fase inicial do mesmo, levando em consideração os diferentes aspetos ambientais, econômicos e sociais.

Por outro lado, a construção sustentável obriga a que se realizem mudanças substanciais no modo como se planeiam e concebem convencionalmente as construções. Os projetos de edifícios sustentáveis usualmente requerem uma abordagem integrada que oriente a tomada de decisões referente ao consumo de recursos (água, energia e materiais), qualidade do ar interior, conforto dos utilizadores e potencial de reciclagem e reutilização dos RCD (MANENT et al., 2009). Ao contrário do projeto convencional, o projeto integrado exige que todos os autores encarem o projeto de maneira holística, baseando a avaliação nos indicadores e parâmetros que são considerados mais representativos nos objetivos da avaliação. Deste modo, um indicador permite efetuar um balizamento de uma solução face a um ou mais objetivos do desenvolvimento sustentável e os seus efeitos complementares nas várias especialidades de projeto e avaliar a sua viabilidade económica em curto e 
longo prazo. O ideal é que cada membro da equipe de projeto integrado tenha um papel e uma área de especialização claramente definida, pelo qual será responsável por determinadas soluções de projeto (KEELER; BURKE, 2010).

Muitas vezes há, para cada projeto, várias soluções ideais que se relacionam de maneira única com as várias especialidades e com o local onde será desenvolvido o edifício. A liderança e a coordenação da equipe se torna crucial durante o processo de discussão e tomada de decisões, uma vez que, para ser eficiente, precisa de adoptar uma abordagem e uma direção determinada.

Logo nas etapas iniciais do desenvolvimento do projeto, devem ser definidos os objetivos que se pretendem obter em termos de sustentabilidade que resultem em metas significativas e mensuráveis que permitam avaliar as opções e o progresso a alcançar. Sobre este aspecto colocam-se duas questões importantes, nomeadamente: Considerando a atual dimensão do Brasil, quais são as melhores estratégias de sustentabilidade a utilizar em cada região? E qual o grau de complexidade que um sistema deverá ter, considerando as eventuais diferenças tecnologias entre regiões? Se não forem levadas em consideração estas questões na fase inicial do projeto, corre-se o risco que o edifício não consiga obter o desempenho pretendido ou então, o mesmo não consiga transpor para a prática os objetivos da construção sustentável.

Deane (2008) referiu que o modelo mais eficaz e eficiente para se conseguir atingir os princípios relacionados com a construção sustentável é por meio de processo de concepção integrado, que envolve a criação de uma equipe de projeto envolvendo todas as partes interessadas (cliente, projetistas, empreiteiro e consultores) desde a fase embrionário do projeto. No caso de projetos sustentáveis as partes interessadas não se devem limitar apenas aos clientes, projetistas, construtores e consultores; devem igualmente incluir membros da comunidades, organizações sem fins lucrativos e diversos decisores locais, de forma a que se consiga integrar no projeto as necessidades da comunidade onde será desenvolvido o edifício.

A abordagem IPD e conforme foi visto, tem vários aspectos claramente diferentes dos sistemas convencionais. Entre eles, apresenta responsabilidades adicionais para a equipa projetista, exigindo um nível de comunicação mais elevado entre os vários agentes envolvidos no projeto. Os atuais softwares pode auxiliar o fluxo de informação e de documentação entre as partes interessadas e garantir que se atenda progressivamente aos objetivos e especificações definidas para o projeto. Esta 
abordagem exige também qualificações especiais por parte dos vários agentes integrantes do projeto, especialmente de compreensão e de compromisso (KIBERT, 2013).

No caso de projetos sustentáveis é importante que os membros da equipe de projeto estejam alinhados com a metodologia "charrete" e que estejam dispostos a incluir no a participação de uma maior gama de partes interessadas que tradicionalmente não costumam ser levados em consideração. O termo "charrete" é uma metodologia usada para conduzir processos de planejamento participativo e multidisciplinar. O principal objetivo é fazer com que o produto sofra o mínimo de interferências possível depois de definido. Todas as partes interessadas intervém ativamente desde a fase embrionária do projeto. A "charrete" ideal deverá incluir no desenvolvimento do projeto, para além das partes interessadas já identificadas, os membros da comunidade local, as organizações sem fins lucrativos e os diversos decisores locais, de forma a que se consiga integrar no projeto as necessidades da comunidade onde será desenvolvido o edifício.

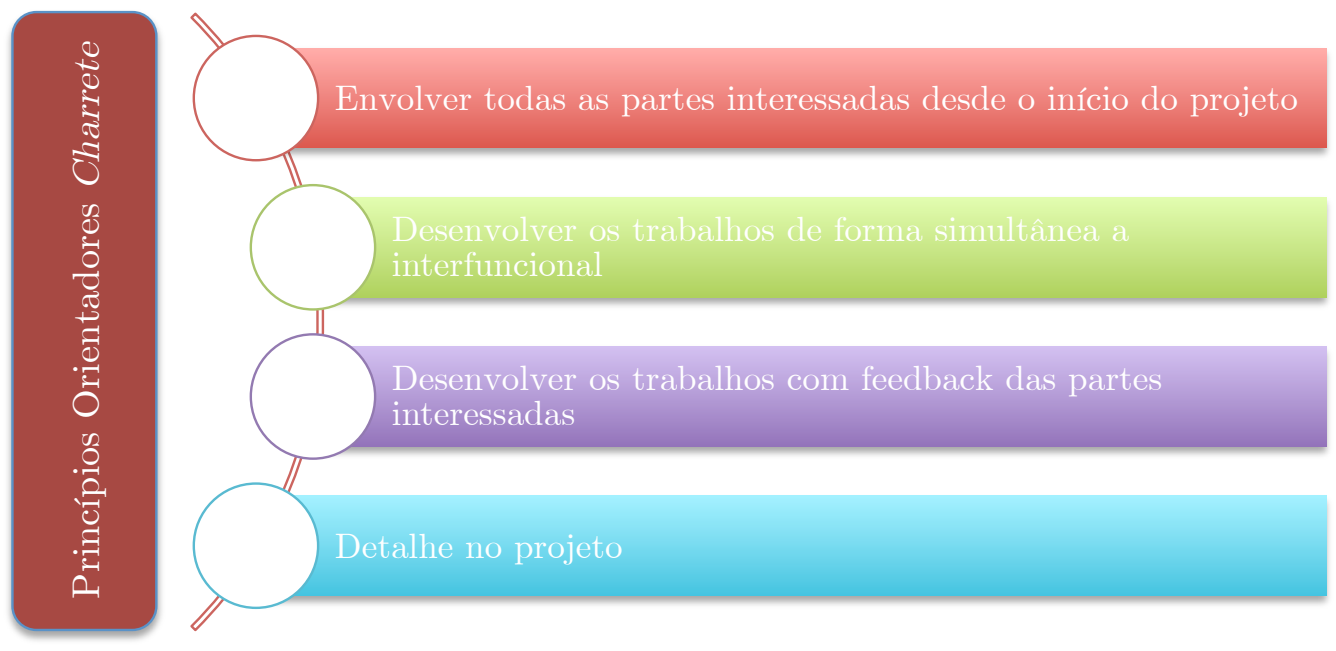

Figura 4.5: Quatro princípios orientadores para metodologia charrete. Adaptado de (KIBERT, 2013)

\section{$>$ Envolver todas as partes interessadas desde o início do projeto}

Como se evidenciou, a identificação e a participação ativa de todas as partes interessadas desde o início do desenvolvimento do projeto é fundamental no processo "charrete". Quanto maior for a participação dos diversos decisores locais, mais provável é a aceitação do edifício pela comunidade, pois durante a concepção as 
preocupações do promotor de obra e do construtor são integradas com as necessidades da comunidade. Admite-se que por meio de partilha de ideias e opiniões criam-se um conjunto de sinergias entre as várias partes interessadas, possibilitando uma maior e melhor compatibilização entre os vários interesses, não só do mercado mas também da sociedade.

\section{Desenvolver os trabalhos simultaneamente e interfuncionalmente}

Todas as disciplinas envolvidas no projeto devem trabalhar simultaneamente durante o processo "charrete", levando em consideração as espectativas das outras partes interessadas. No âmbito do processo "charrete" tende a haver um maior leque de soluções construtivas, uma vez que as entradas/informações a considerar no projeto são maiores. Por conseguinte, há medida que o projeto evolui o nível de detalhe das destas soluções construtivas vai aumentando gradualmente, abrangendo não só as questões ambientais mais também a função do edifício dentro da comunidade. Em projetos mais complexos, a participação dos vários participantes da comunidade podem dividir-se em grupos de trabalho distintos para abordar questões específicas. Em seguida, e por meio de uma reunião plenária, compartilhar aos diversos participantes o progresso realizado em cada grupo, permitindo uma maior eficácia na compatibilização da informação.

\section{$>$ Desenvolver os trabalhos com Feedback das partes interessadas}

A existência de reuniões de trabalho e workshops públicos, originando um feedback para a equipa projetista, em diversos estágios de desenvolvimento de projeto evita que se tenham de realizar alterações ao projeto, permitindo assim economia de custos e tempo.

\section{$>$ Detalhe no Projeto}

A "charrete" é um processo holístico e iterativo, em que as várias soluções construtivas edifício (orientação, volumetria, sistemas elétricos, sistemas mecânicos, etc.) vão sendo sucessivamente detalhadas de forma a integrar as necessidades e espectativas das várias partes interessadas. A equipe projetista deve abordar potenciais problemas em diferentes escalas durante o processo "charrete" tais como iteração do edifício com outros edifícios já existentes, com a pavimentação e a rua, com o sistema de drenagem, tipo de materiais, entre outros. 


\subsubsection{Influências das Decisões de Projeto no Ciclo de Vida de um Edifício}

Segundo Ferreira (2013) a fase de projeto é aquela em que as principais decisões relativas ao desempenho de um edifício são elaboradas e desenvolvidas. Consequentemente, as decisões tomadas nesta fase são fundamentais para se conseguir incorporar no edifício, medidas e soluções construtivas com princípios de sustentabilidade. No entanto, este processo envolve geralmente tarefas e procedimentos que podem ser complexos, para além da necessidade de analisar um número significativo de critérios, não só ambientais, como também econômicos e sociais. Por este motivo, é importante que o projeto seja desenvolvido recorrendo a uma abordagem que incorpore múltiplos critérios e que envolvam uma análise de diferentes alternativas de soluções de projeto (REKOLA et al., 2012). Tendo por base a Norma ISO 15.392:2008 as soluções de projeto segundo os princípios da construção sustentável devem levar em consideração:

i. Aspetos ambientais: Tradicionalmente o foco da construção sustentável de edifícios é maioritariamente direcionado para este aspeto. Envolve aspectos relacionados com os trabalhos da construção, processos ou serviços relacionados ao seu ciclo de vida, pode interagir com o meio ambiente. Envolve questões que dizem respeito aos impactos com a quantidade e qualidade dos recursos, ecossistemas locais, regionais e globais; incorporar uma avaliação LCA para avaliar o impacto do edificado sobre o meio ambiente, incluindo produtos e serviços utilizados durante a construção;

ii. Aspetos econômicos: Envolve aspectos relacionados com os trabalhos da construção, processos ou serviços relacionados ao seu ciclo de vida que pode interagir com impactos económicos que se estende para além da vida útil da obra da construção. Aborda questões relacionadas aos custos e benefícios que medem o impacto para a economia, relutante das atividades, produtos ou serviços utilizados na construção, incluindo a utilização e manutenção;

iii. Aspetos sociais: Envolve aspectos relacionados com os trabalhos da construção, processos ou serviços relacionados ao seu ciclo de vida que pode interagir com a sociedade ou qualidade de vida, tais como conforto térmico e acústico, acessibilidades, bons níveis de iluminação natural e qualidade do ar interior. Os aspetos sociais incluem também o impacto sobre futuras gerações, bem como tradições e culturas. 
Neste enquadramento, se o projeto for bem planeado incluindo os aspetos de sustentabilidade logo nas primeiras fases do seu desenvolvimento a possibilidade de reduzir os impactos negativos é maior, bem como o custo de implementação será menor, conforme ilustrado na figura 4.6. Com efeito, admite-se que nas fases iniciais de projeto é possível encontrar sinergias que e as soluções mais simples que tornam possível na prática os objetivos da construção sustentável.

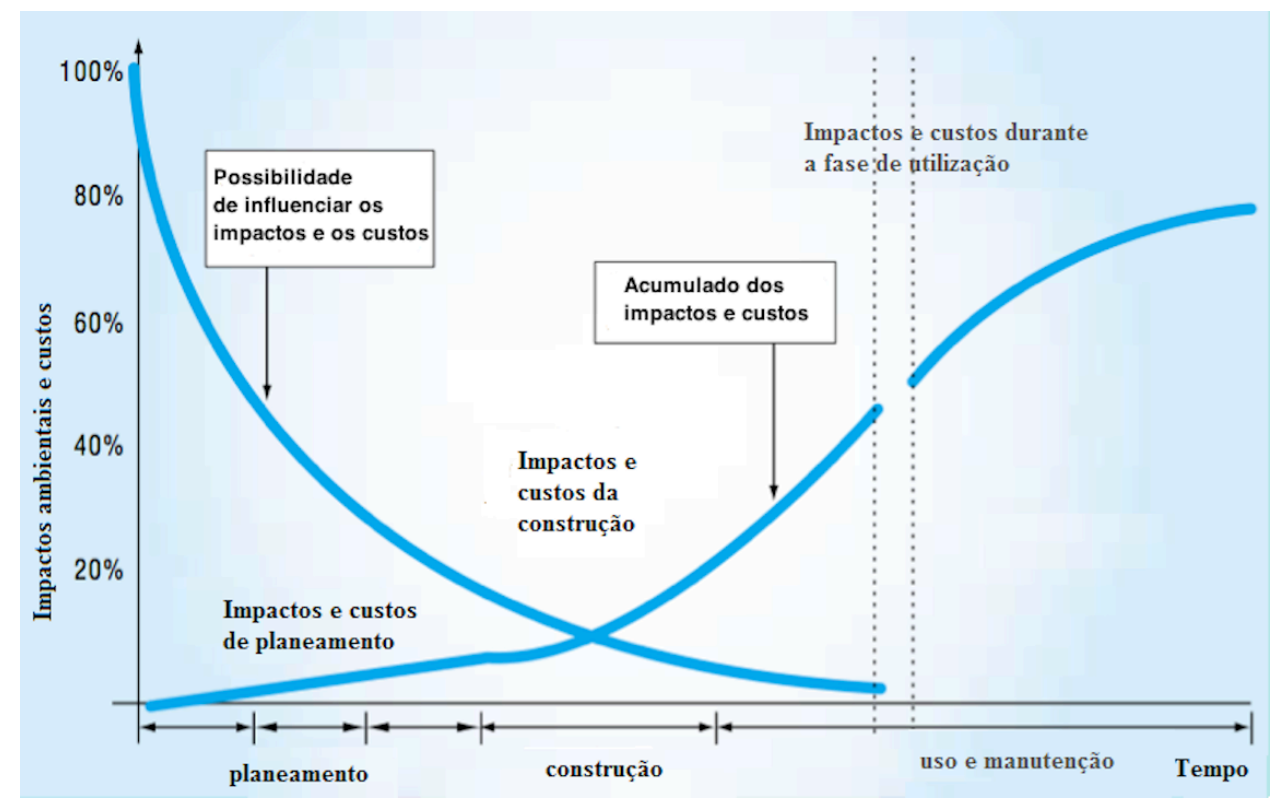

Figura 4.6: Influência das decisões tomadas nas várias fases do ciclo de vida de um edifício nos respetivos impactos ambientais e de custos. Traduzido de (KOHLER; MOFFATT, 2003)

A importância das primeiras fases de projeto está igualmente bem documentada no Guia PMBOK, no qual enfatiza que a capacidade de influenciar as características finais do produto do projeto, sem impacto significativo sobre os custos, é mais elevada no início e vai diminuindo conforme o projeto evolui para o seu término (PMBOK, 2013).

Um estudo apresentado por Pocock, et al. (2006) procurou determinar, através de um inquérito, em que momento ocorre um maior esforço/intensidade para otimizar os objetivos globais do empreendimento. As respostas ao inquérito foram provenientes dos vários intervenientes na construção civil (arquitetos, engenheiros, consultores, promotores de obra, etc.). A figura 4.7 apresenta os resultados desse inquérito, 
destacando que o esforço para se atingir o nível ótimo de construtibilidade ${ }^{9}$ ocorre principalmente na fase de concepção de projeto, sendo que a partir da adjudicação do contrato, esse esforço deve ser mínimo.

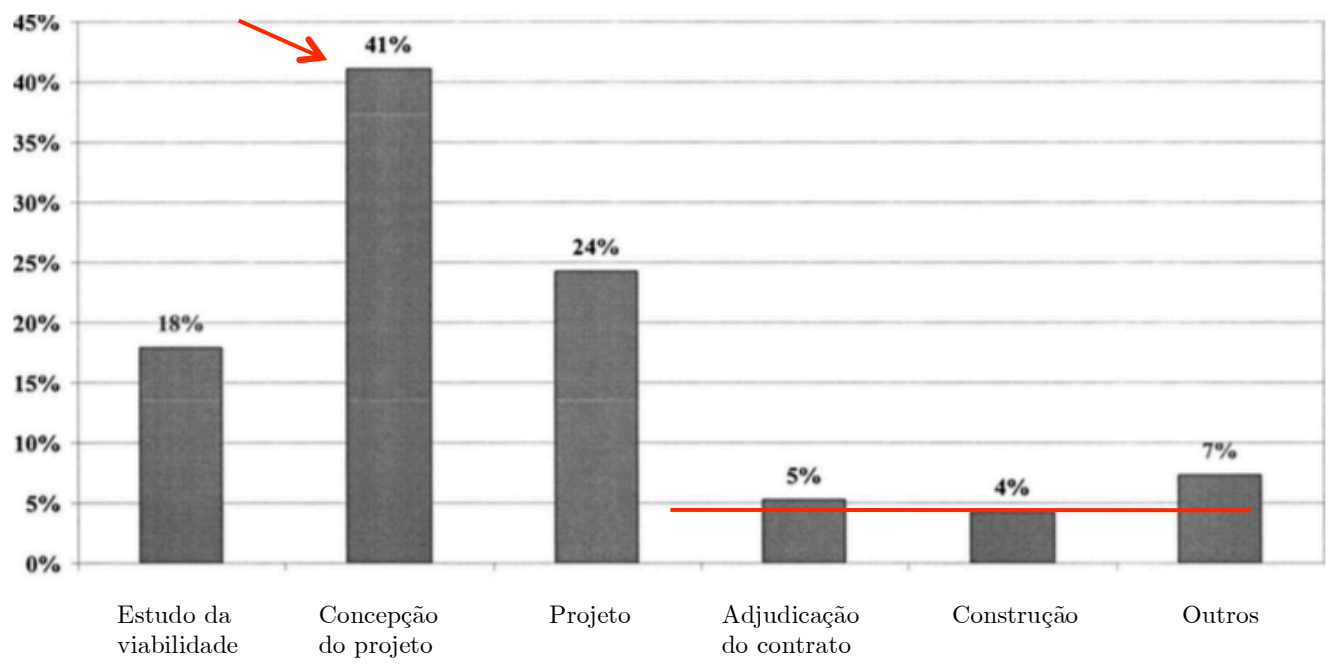

Fases de ciclo de vida de um edifício

Figura 4.7: Durante que fase de se inicia o esforço referente à construtibilidade? traduzido de (POCOCK et al., 2006)

Pela análise da figura 4.7, verifica-se que o esforço relativamente à construtibilidade começa nas fases iniciais de projeto; $59 \%$ dos entrevistados acreditam que se inicia mesmo antes do projeto de execução e $83 \%$ dos entrevistados afirmam que se inicia antes da adjudicação do contrato. Ainda sobre este estudo é importante referir que o mesmo foi conduzido nos EUA e não no Brasil, no entanto as conclusões que os autores chegam permitem fornecer dados internacionais relevante demonstrando a importância do projeto.

A figura 4.8 apresenta uma comparação entre os projetistas, promotores de obra e construtores. No caso dos projetistas, verifica-se que ao longo das várias fases de desenvolvimento do projeto, $59 \%$ dos inquiridos acredita que é na fase da concepção de projeto que o esforço em termos de contrutibilidade se inicia.

${ }^{9}$ O termo construtibilidade pode ser definido como a integração de conhecimentos e experiência durante as fases de estudo de viabilidade, concepção e desenvolvimento do projeto, contratação e construção, para atingir os objetivos globais do empreendimento. 


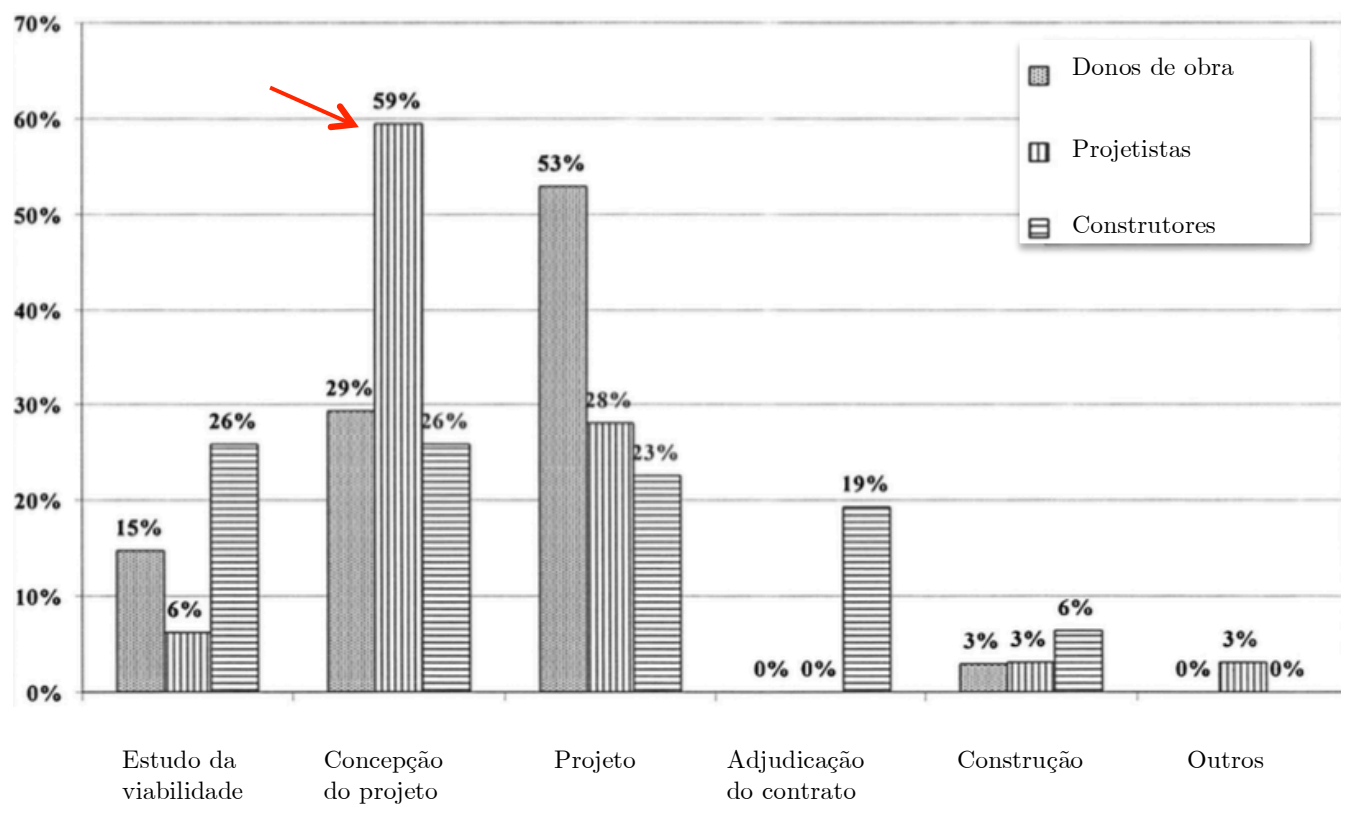

Fases de ciclo de vida de um edifício

Figura 4.8: Comparação de quando o esforço de construtibilidade normalmente se inicia. Traduzido de (POCOCK et al., 2006)

O mesmo autor conduziu também um inquérito para determinar os maiores obstáculos na implementação da construtibilidade. Os resultados foram conclusivos; o mais frequente foi a falha de comunicação entre os projetistas e os construtores (64\%); inadequada experiência construtiva (45\%), deste valor importa referir que $50 \%$ correspondeu aos projetistas e apenas $12 \%$ aos construtores; e dificuldade na coordenação das várias especialidade de projeto (44\%).

O primeiro obstáculo é muito comum no processo tradicional de concepção-concursoconstrução em que o construtor pouca oportunidade tem de participar durante o desenvolvimento do projeto, prejudicando a comunicação entre construtor e projetistas. Para contrariar este fenômeno, os Promotores da obra podem selecionar tipos de contratos mais apropriados, exigindo um processo formal que incorpore a experiência em construção no início do projeto, por exemplo o processo IPD, analisado no subcapítulo anterior, permite estabelecer um canal de ligação entre os projetistas e construtores logo no inicio do processo. 
Analisando os resultados do inquérito do artigo e comparando com a literatura existente referente ao conceito de construtibilidade, podem-se retirar as seguintes conclusões e recomendações:

1. A maioria dos esforços relativos à construtibilidade iniciam-se na fase embrionária do projeto. Após finalizado o projeto de execução o esforço de construtibilidade é mínimo;

2. A experiência na construção, começa a ser aplicada nas fases iniciais de projeto e não apenas quando a obra se inicia;

3. Engenheiros e arquitetos devem tornar-se mais familiarizados com a prática e gestão da construção por meio de uma formação adequada e experiência no canteiro de obras. As universidades devem reforçar/introduzir disciplinas que abordem os conceitos de construtibilidade, métodos construtivos, entre outros, não só na formação dos engenheiros mas também dos arquitetos. As empresas também devem promover oportunidades de treinamento e inspeções ao canteiro de obras para os projetistas, integrado estas tarefas como parte necessária do seu desenvolvimento profissional (POCOCK et al., 2006);

4. Existe um amplo reconhecimento dos vários benéficos associados a este conceito.

5. Construtores devem tentar incluir métodos, materiais, tecnologias e equipamentos que permitam melhorar contrutibilidade.

No subcapítulo seguinte irá ser analisado algumas considerações de sustentabilidade que os projetistas deverão ter consideração durante a elaboração de um projeto. Este aspecto foi o principal foco de estudo deste trabalho que, juntamente com os fundamentos de projeto integrado, resultou na materialização da ferramenta que se propõe apresentar.

\subsection{Algumas Considerações de Sustentabilidade nas Várias Fases de Projeto}

A elaboração de um projeto é um processo iterativo, realizando-se aproximações sucessivas ao pretendido pelo Promotor de obra. As várias fases de desenvolvimento do projeto formam uma sequência de estados que proporciona ao gestor do projeto uma estrutura básica para a sua gestão, independentemente do tamanho e complexidade que este possa apresentar. Para elaboração de um projeto, as etapas 
previstas são definidas através dos requisitos expressos na norma brasileira NBR 13.531/1995, que distribui o seu faseamento de acordo com a figura 4.9.

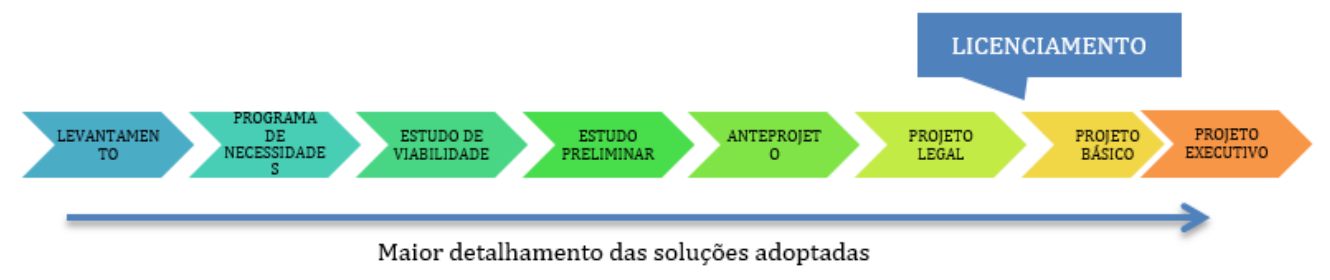

Figura 4.9: Fases de desenvolvimento de um projeto de acordo com a norma brasileira, adaptado de (NBR 13531, 1995)

Seguidamente irão ser analisadas algumas dessas fases, nomeadamente, a fase do programa de necessidades, o estudo de viabilidade, o estudo preliminar, o anteprojeto, o projeto legal e o projeto de execução. Serão também identificados alguns aspetos da sustentabilidade a considerar em cada uma dessas etapas.

\subsubsection{Programa de Necessidades e Estudo de Viabilidade}

Como se evidenciou anteriormente, a inclusão da procura de sustentabilidade desde a fase inicial é fundamental. Nestas duas etapas define-se os pressupostos que deverão ser considerados pelos projetistas, como usos do edificado, localização, tipologias e número de divisões, entre outras informações que sejam relevantes (NBR13531, 1995). Envolve a participação dos principais intervenientes do projeto, juntamente com o Promotor de obra, no sentido de saber as exigências no que diz respeito ao projeto em termos de qualidade, prazo e custo, bem como a sensibilização do Promotor de obra para as questões da sustentabilidade da construção. Os objetivo básicos da sustentabilidade devem ser estabelecidos já no inicio do projeto, o que resulta em metas significativas que permitem avaliar as opções e o progresso alcançado. Em vez de prescrever soluções específicas, esses objetivos devem estipular metas mensuráveis e de fácil compreensão para o desempenho da habitação (KEELER; BURKE, 2010). Deste modo o programa deve discriminar as intenções do Promotor de obra para o nível de desempenho em termos de sustentabilidade que se pretende atingir. Sobre este aspecto é importante mencionar que muitas vezes o Promotor de obra não está ciente dos benefícios associados à construção sustentável, dando frequentemente prioridade ao preço em prejuízo da qualidade. Cabe pois à equipa projetista sensibilizar ao Promotor de obra para a adopção de tecnologias e métodos construtivos com baixo impacto ambiental, flexíveis e com boa qualidade arquitetônica de conforto e salubridade para os utilizadores. Na realidade as 
orientações começam por servir para refletir que aspectos devem ser considerados e após a sua definição deve-se elencar os aspectos a serem considerados no projeto nas etapas seguintes. Nesta etapa de projeto é importante considerar os seguintes aspetos:

- Identificar as condicionantes legais ambientais;

- Identificar os princípios de sustentabilidade a considerar no projeto;

- Identificar o posicionamento do Promotor de obra quanto ao nível de sustentabilidade a atingir pelo edifício: não certificável, certificável, desempenho equilibrado, bom desempenho, etc.;

- Outras orientações que possam ser importantes para desenvolvimentos a considerar pelos projetistas.

Como ainda se está na fase inicial do projeto, pode ainda haver alguma abertura para abordar alguns aspetos, por exemplo a localização e escolha de um terreno com baixo impacto ambiental, tais como reabilitar áreas contaminadas, degradadas ou abandonadas; facilitar a acessibilidade e a mobilidade, promovendo a variedade e a qualidade das amenidades locais e facilitar a integração social.

\subsubsection{Estudo Preliminar}

O estudo preliminar destina-se à concepção e à representação do conjunto de informações técnicas iniciais, necessários à compreensão da configuração do edificado, podendo incluir soluções alternativas (NBR13531, 1995). Nesta etapa é importante considerar os seguintes aspetos de sustentabilidade:

- Analisar as opções estratégicas de projeto para incluir as melhores soluções que cumpram com os princípios de sustentabilidade e se as mesmas seguem as estratégias inicialmente delineadas;

- Garantir a satisfação das condicionantes legais ambientais.

Nesta fase os projetistas devem ter em conta as características do local (topografia, envolvente construída) de forma a possibilitar uma orientação otimizada, uma boa integração e deve permitir a criação de zonas exteriores permeáveis. No que diz respeito aos recursos naturais (sol, água e vento), deve-se optar por uma estratégia energética que englobe os sistemas passivos da arquitetura bioclimática e possibilite o eventual emprego de sistemas ativos. Os sistemas passivos da arquitetura bioclimática vão no sentido de tentar evitar ao máximo a introdução de equipamentos mecânicos. O aspeto que mais influência é a zona climática onde o 
edifício se insere (quente/seco, quente/húmido, temperado ou frio). Por este motivo, os projetistas devem considerar diferentes estratégias na concepção do edifício.

A envolvente deve ser cuidadosamente estudada de modo a ser compatível com o local de implantação e orientação do edifício. Também os requisitos básicos da iluminação natural e ventilação natural devem ser levados em conta no estudo preliminar. Tendo em conta que a iluminação natural é o tipo de iluminação mais eficiente, edifícios devem ser concebidos de modo a que todos os compartimentos possuam iluminação natural. Esta pode ser conseguida através de janelas, claraboias e tubos solares

De forma igual, o nível de consumo de água, os projetistas devem considerar soluções, quer para a recolha de água das chuvas, quer para a eventual reutilização da própria água.

Ainda nesta fase os projetistas devem projetar o edifício prevendo o seu futuro desmantelamento e não apenas a demolição. Deve-se evitar a ligação entre os diversos elementos de construção de forma inseparável e a utilização de materiais compósitos que não possam ser separados.

Em suma, o Estudo Prévio deve interpretar os objetivos definidos pelo Promotor de obra, definidos anteriormente, e procurar encontrar a concretização e a viabilidade das soluções a adotar.

\subsubsection{Anteprojeto}

Esta etapa destina-se à concepção e representação das informações técnicas provisórias de detalhamento da edificação. O detalhe técnico das soluções apresentadas devem ser suficientes para permitir a elaboração de estimativas aproximadas de custo e de prazos dos serviços de obra implicados (NBR13531, 1995). Nesta etapa é importante considerar os seguintes aspetos de sustentabilidade:

- Aferir se as soluções propostas seguem as estratégias inicialmente delineadas e se estão de acordo com os princípios traçados, assegurando uma abrangência generalizada e o caminho para a sustentabilidade, que foi inicialmente definido e analisado;

- Analisar as opções estratégicas de forma a avaliar a sua compatibilidade com o programa pretendido pelo promotor de obra, quer ao nível da aferição de 
orçamento, que ao nível dos requisitos expressos em termos de sustentabilidade;

A seleção das soluções construtivas definidas no projeto devem ter em consideração a sua durabilidade, análise global dos custos da solução, comportamento térmico, impacto ambiental, disponibilidade de técnicos e de empresas de construção, disponibilidades dos materiais no mercado, manutenção esperada, distância de transporte, flexibilidade da solução e o seu potencial de reutilização/reciclagem.

A equipa projetista deve ter atenção à geometria solar do local, tendo em consideração os ganhos solares na cobertura, paredes e envidraçados. Estes ganhos podem contribuir tanto positivamente como negativamente para as necessidades de aquecimento, arrefecimento e conforto dos ocupantes.

A temperatura do edifício não depende apenas da transmissão térmica verificada ao nível da envolvente, mas também da quantidade de calor que é produzida pelos ocupantes e equipamentos. Desta forma, é importante para a equipa projetista conhecer este fator, pois além de condicionar a temperatura interior, vai influenciar também a taxa a que se verificam as trocas de calor entre o espaço interior e exterior, visto que as perdas de temperatura através da envolvente do edifício são proporcionais às diferenças de temperatura entre os dois espaços.

O edifício deve apresentar a adequada resistência térmica, ao nível das fachadas, empenas, coberturas e pavimentos. O estudo incorreto da solução de isolamento térmico dos elementos da envolvente pode comprometer o conforto interior, interferindo com a quantidade de energia consumida nas ações de controlo da temperatura interior.

Deve ter-se em consideração a escolha dos materiais, para além das condicionantes regulamentares, e ainda ter em conta outros fatores relacionados com o impacto ambiental; devem ser utilizados materiais e sistemas que não apresentem CFC/HCFC, amianto, chumbo, formaldeído, radão, tolueno, xileno, entre outros.

A entrada de luz natural do edifício, através de janelas ou outros sistemas, também merece um estudo aprofundado; a sua distribuição, proporção relativamente à parte opaca e a concepção influenciam o comportamento do edifício. Portanto, é conveniente que neste estudo o dimensionamento seja feito em conjunto com o projeto de características de comportamento térmico dos edifícios, de forma a 
permitir que a entrada de luz natural seja suficiente, sem por em causa o comportamento térmico do edifício.

A racionalização do consumo de água também poderá ser um aspeto a levar em conta, sobretudo nas sanitas, chuveiros e torneiras; estes são pontos críticos onde se pode atuar, de modo a diminuir o consumo de água.

\subsubsection{Projeto Legal}

Esta etapa destina-se à representação das informações técnicas necessárias à análise e aprovação, pelas entidades competentes, da concepção da edificação e seus elementos e instalações, com base nas exigências legais. É nesta fase e sob forma de projeto de licenciamento que o promotor de obra submete à apreciação das autoridades legais (municipal, estadual, federal) para obtenção do alvará ou das licenças necessárias à execução da obra (NBR13531, 1995).

O projeto legal deverá efetuar a escolha das soluções através de um balanço equilibrado entre o pretendido pelo promotor de obra e os níveis de sustentabilidade a serem considerados. Assim, são descritas abaixo, as principais linhas a considerar no âmbito da sustentabilidade:

- Satisfazer os requisitos legais ambientais incluindo os energéticos através da norma de desempenho NBR 15.575:2013 - Edificações Habitacionais;

- Avaliar o nível de sustentabilidade que se procura, atingiu ou vai atingir dentro dos requisitos inicialmente delineados;

- Orientações para desenvolvimentos a considerar no futuro, quer na fase de projeto de execução, quer na fase de construção, operação, ou até mesmo demolição/desconstrução;

Nesta fase, é importante a equipa projetista ter em consideração o tipo de envidraçado a aplicar nos vãos, de modo a otimizar o comportamento dos envidraçados do edifico. O ideal passa por escolher envidraçados que apresentem preferencialmente fator solar mínimo, coeficiente de transmissão térmica mínimo e fator de transmissão luminosa elevado.

Deve-se ter em consideração à refletividade do acabamento exterior da envolvente. Em zonas climáticas onde se prevejam elevados ganhos de temperatura através da envolvente opaca é de todo o interesse escolher materiais de acabamento exterior de cor clara e elevada refletividade. 
Também é importante prevenir condensações no interior do edifício. Esta situação conduz à perda de parte da sua performance térmica e à sua degradação precoce. Este fenómeno pode ser contornado recorrendo a introdução de barreiras pára-vapor, tais como ventilação adequada, tintas não impermeáveis, aditivos antifúngicos, sistemas de desumidificação, etc.

Relativamente à iluminação artificial é conveniente que o tipo de lâmpada seja adequado à utilização do espaço. Assim, em zonas que necessitem de iluminação artificial por longos períodos de tempo é apropriado o uso de lâmpadas fluorescentes (economizadoras), enquanto que em zonas onde é preciso luz de imediato e por curtos períodos de tempo, as lâmpadas mais adequadas são as incandescentes.

Deve-se igualmente optar por soluções de iluminação eficiente em cada compartimento do edifício, através da utilização de interruptores "inteligentes" e prever a existência de vários circuitos de iluminação em cada espaço.

Para diminuir os riscos para a saúde dos ocupantes, dever-se-á evitar o uso de adesivos, selantes, pinturas, vernizes e revestimentos que possuam elevadas quantidades de Compostos Orgânicos Voláteis (COV).

Relativamente aos sistemas de aquecimento/arrefecimento e Águas Quentes Sanitárias (AQS) é de todo o interesse em selecionar equipamentos com bons/elevados rendimentos.

Nesta fase do projeto legal é possível recorrer a sistemas de ACV, permitindo um estudo sobre os impactos ambientais dos produtos e materiais a utilizar, associados à totalidade do seu ciclo de vida.

\subsubsection{Projeto de Execução}

O projeto de execução corresponde à última etapa e consiste na representação final das informações técnicas da edificação e de seus elementos necessários à fácil e inequívoca interpretação por parte das entidades intervenientes na execução da obra (NBR13531, 1995).

Nesta fase parte-se do pressuposto que já existiu a coordenação entre a arquitetura e as várias especialidades nas fases anteriores, pelo que o problema consiste na pormenorização das soluções inerentes a cada uma das especialidades envolvidas. 
Soluções que requerem utilização de energia renováveis, recolha e aproveitamento de águas e uso de materiais certificados, são aspetos que requerem pormenorização ao nível dos recursos.

Para reduzir as variações de temperatura por convecção, deverão ser desenvolvidas formas de evitar as trocas de calor através de entradas e saídas de ar não controladas, muito usual nas juntas de elementos construtivos, tais como portas e janelas. Nestes casos deverão ser estudadas soluções de calafetagem, que utilizem materiais com baixo impacto ambiental e que não comprometam a qualidade do ar interior. No que diz respeito às variações de temperatura por condução, através das pontes térmicas, é necessária a execução de pormenores desses locais, com a finalidade de controlar as perdas/ganhos de temperatura.

Também se deve optar por selecionar eletrodomésticos com um baixo consumo de energia, apesar de terem um custo mais oneroso em relação aos de elevado consumo de energia, que podem acabar por acarretar menores custos em termos globais, ou seja, durante o seu ciclo de vida.

Relativamente aos resíduos, devem ser detalhados locais para a deposição dos mesmos, tais como os ecopontos, bem como locais para a realização da compostagem. Ao nível do conforto do utilizador, nomeadamente da iluminação, é necessário garantir bons níveis de iluminação. Para tal é preferível acabamentos de cor clara nas superfícies interiores e no mobiliário, uma vez que estes refletem melhor a luz; também é importante assegurar que se aplicam lâmpadas com potência adequada à iluminação necessária.

Na qualidade do ar interior do edifício devem ser detalhadas soluções que fomentem a ventilação natural. A utilização de fachadas ou coberturas verdes são outros dos aspetos a ser detalhados.

A importância de adaptar diferentes estratégias ao longo do desenvolvimento do projeto é muito bem retratada no manual do Green Vitruvius - Principles and Practice of sustainable Architectural Design (2011). De acordo com este manual, estabelece-se as seguintes considerações ao longo do ciclo de evolução de um projeto (tabela 4.2). 


\begin{tabular}{|c|c|}
\hline Fase do Projeto & Estratégias \\
\hline \multirow{3}{*}{$\begin{array}{l}\text { Programa de } \\
\text { Necessidades e }\end{array}$} & O projeto verde deve ser identificado como uma questão a ser considerada \\
\hline & Acordar objetivos de comportamento ambiental do edifício \\
\hline & \\
\hline & $\begin{array}{l}\text { Dar preferência a terrenos degradados (brownfield) ou abandonadas, bem como } \\
\text { levar em conta a proximidade a transportes públicos e unidades de serviços. }\end{array}$ \\
\hline Viabilidade & \\
\hline \multirow{4}{*}{ Estudo Preliminar } & Analisar a qualidade dos ecossistemas e biodiversidade local \\
\hline & Analisar o local para avaliar as condições de luz natural e sombreamento \\
\hline & $\begin{array}{l}\text { Pesquisa local em relação à tipologia do edifícios e analisar exemplos de boas } \\
\text { práticas }\end{array}$ \\
\hline & Considerar aquilo que é possível atingir com as limitações económicas \\
\hline \multirow{5}{*}{ Anteprojeto } & $\begin{array}{l}\text { Otimizar a orientação do edifício em relação às estratégias passivas, incluindo } \\
\text { radiação solar e iluminação natural. }\end{array}$ \\
\hline & Avaliar as opções passivas de aquecimento, arrefecimento e ventilação \\
\hline & Considerar a inércia térmica para reduzir as flutuações de temperatura \\
\hline & Considerar métodos de abastecimento de água e gestão dos resíduos \\
\hline & Efetuar estudos iterativos de projeto para avaliar o desempenho do edifício \\
\hline \multirow{6}{*}{ Projeto Legal } & $\begin{array}{l}\text { Otimizar a proporção e a distribuição das aberturas na envolvente exterior, } \\
\text { considerando o sistema de arrefecimento/aquecimento e iluminação. }\end{array}$ \\
\hline & $\begin{array}{l}\text { Considerar dimensões adequadas aos vários espaços, por exemplo pé direito, } \\
\text { tendo em vista a iluminação natural, arrefecimento ou aquecimento }\end{array}$ \\
\hline & $\begin{array}{l}\text { Verificar inércia térmica face ao padrão de utilização do edifício: intermitente } \\
\text { ou contínuo }\end{array}$ \\
\hline & Especificar critérios de projeto para serviços \\
\hline & $\begin{array}{l}\text { Selecionar materiais e métodos construtivos considerando a massa térmica e } \\
\text { questões de ciclo de vida }\end{array}$ \\
\hline & Calcular previamente o desempenho energético do edifício \\
\hline \multirow{6}{*}{$\begin{array}{l}\text { Projeto de } \\
\text { Execução }\end{array}$} & $\begin{array}{l}\text { Detalhes de projeto para otimizar o desempenho térmico, iluminação e controlo } \\
\text { da ventilação }\end{array}$ \\
\hline & Especificar esquadrias de janelas e portas considerando o desempenho energético \\
\hline & $\begin{array}{l}\text { Analisar o desempenho de ciclo de vida de componentes, materiais e } \\
\text { acabamentos }\end{array}$ \\
\hline & $\begin{array}{l}\text { Os equipamentos mecânicos de AVAC devem ter em conda o seu desempenho } \\
\text { ambiental }\end{array}$ \\
\hline & $\begin{array}{l}\text { Especificar equipamentos de iluminação e sistemas elétricos eficientes } \\
\text { energeticamente }\end{array}$ \\
\hline & Especificar dispositivos sanitários com baixo consumo de água \\
\hline
\end{tabular}

Tabela 4.2: Estratégias de sustentabilidade em projeto segundo o manual (BROPHY; LEWIS, 2011)

Considerando os diferentes desafios que se colocam em cada fase de projeto, tanto na arquitetura como nas várias especialidades da engenharia, o presente trabalho 
procurou desenvolver uma ferramenta inovadora que permita auxiliar na concepção de projetos com requisitos e preocupações de sustentabilidade. Embora tenha sido desenvolvido principalmente para o contexto brasileiro, a abordagem em si poderia ser customizada em outros países, como o caso de Portugal.

Para além disto, é igualmente importante, durante a concepção do projeto uma estreita colaboração entre os principais intervenientes seguindo os princípios de processo de concepção integrado. Este novo paradigma de construção sustentável, deve ser levado em conta desde a fase inicial de desenvolvimento de projeto, até à sua conclusão.

A construção sustentável, desde o seu aparecimento tem crescido de forma exponencial, tendo surgido numerosas organizações tanto públicas como privadas para apoiar a sua agenda. É importante entender os seus problemas e os limites atuais para se promover uma trajetória adequada na forma como se concebem atualmente os edifícios. Sobre esta matéria, o presente trabalho procurou ser um contributo através da elaboração de uma ferramenta inovadora. Nos próximos capítulos (5 e 6) irá ser detalhado os métodos adoptados no seu desenvolvimento e a forma como esta se encontra estruturada e organizada. 


\section{CAPÍTULO 5 - MÉTODO ADOPTADO NO DESENVOLVIMENTO DA FERRAMENTA}

Conforme referido anteriormente, o objetivo deste trabalho consiste no desenvolvimento de uma ferramenta que, de forma integrada e coordenada, permita orientar o desenvolvimento de soluções sustentáveis ao longo das diferentes etapas de evolução de um projeto (estudo preliminar, anteprojeto, projeto legal e projeto de execução).

Neste sentido, a pesquisa iniciou-se tendo por base um estudo aprofundado da literatura existente, abordando a temática da gestão de projetos e a sustentabilidade na construção de edifícios. Deste modo, a pesquisa bibliográfica permitiu obter informações relevantes sobre as várias metodologias de avaliação de sustentabilidade, com destaque para Análise de Ciclo de Vida (ACV) e sistemas de certificação de sustentabilidade. Permitiu também adquirir conhecimentos relevantes associados à gestão de projetos, permitindo entender a sua importância para se atingir níveis de sustentabilidade superiores à pratica, com destaque para o processo de concepção integrado. Durante esta etapa foram levados em consideração artigos científicos (nacionais e internacionais), livros e dissertações, conforme abordado no estado de arte da presente dissertação.

Numa fase posterior e já de amadurecimento das informações obtidas na pesquisa bibliográfica, procurou-se elaborar uma ferramenta que permitisse auxiliar não só o gestor de projetos na coordenação das várias especialidades, mas também auxiliar os vários projetistas nos passos a dar para incorporar no projeto medidas e soluções construtivas com requisitos de sustentabilidade. Neste sentido, a pesquisa bibliográfica foi fundamental para a coleta de dados que serviu de base para elaboração da ferramenta que se propõe apresentar. Foi tido em consideração os princípios básicos e fundamentais da gestão de projetos, com ênfase no processo de concepção integrado. Para se conseguir atingir de uma forma mais eficiente este objetivo a ferramenta foi estruturada em duas fases bem distintas. A primeira fase está direcionada unicamente para o Gestor de Projeto, permitindo ao mesmo acompanhar e monitorizar o andamento do projeto desde a fase inicial até à sua conclusão, de forma a identificar, em cada etapa de projeto sobre o que está ou não a ser incorporado; permitindo corrigir eventuais desvios que sejam necessários. A 
segunda fase está direcionada unicamente para os projetistas que intervêm nas principais especialidades de projeto (arquitetura, estruturas, instalações elétricas mecânicas e hidráulicas). A forma como a segunda fase foi estruturada permite que se criem sinergias entre os vários membros da equipe de projeto, por meio de uma comunicação mais eficiente entre as várias especialidades, bem como a disponibilização de informação técnica necessária para que estes tenham a possibilidade de influenciar o desempenho do edifício desde a fase inicial de projeto até à sua conclusão. Estas duas fases distintas constituem a ferramenta de apoio ao desenvolvimento de projetos sustentáveis. No capítulo 6 desta dissertação será exposta a forma como a ferramenta funciona e como se encontra estruturada e organizada.

Importa referir que não foram realizados estudos de caso, por meio de uma simulação a um projeto real, que permitisse validar e otimizar a ferramenta. Sendo que esta atividade pode vir a ser realizada no âmbito de um doutorado permitindo ao pesquisador identificar os benefícios e dificuldades na aplicação desta Ferramenta. Contudo, e apesar de não ter sido possível realizar os estudos de caso, optou-se por submeter a ferramenta à avaliação de um especialista da área.

\subsection{Seleção da Metodologia de Avaliação de Sustentabilidade Adoptada na Ferramenta}

Como se evidenciou no capítulo 3, atualmente existem várias metodologias de avaliação de sustentabilidade no edifícios, com destaque para o ACV e os sistemas de certificação. É largamente reconhecido na área de avaliação da sustentabilidade dos edifícios que o ACV constitui o método preferível na quantificação dos impactos ambientais derivados da produção de produtos e materiais construção, soluções construtivas ou o edifício no seu todo. No entanto, apesar de todas as vantagens associadas ao AVC, também apresenta várias contrapartidas. O maior entrave de é o elevado grau de exigência que todo o processo de ACV apresenta. É uma metodologia extremamente valiosa, pela precisão com que funciona, mas os procedimentos são muito complexos e exige uma especialização muito elevada a quem a utiliza. Mais ainda, no caso dos edifícios, englobam um elevado número de materiais diferentes, uma grande variedade de empresas envolvidas (os processos produtivos podem variar de empresa para empresa) e, para dificultar ainda mais a tarefa, é necessário prever o longo ciclo de vida do edifício (décadas ou mesmo séculos, nalguns casos), que só por si comporta inúmeras incertezas. Acresce a estes factos, a baixa padronização 
verificada no setor da construção civil, que torna esta análise única para cada caso e a falta de iniciativas para criação de DAP de produtos que são fundamentais para uma análise rigorosa do processo. Por este motivo o $\mathrm{ACV}$, grande parte devido à sua complexidade, a maior parte das ferramentas são utilizadas e desenvolvidas apenas por especialistas, e na maioria das vezes a nível de investigação (MATEUS, 2011).

Com efeito, e considerando os factos supracitados, não foi incluído o ACV na ferramenta uma vez que se pretende que a mesma possa ser de fácil operacionalização. Sobre este aspecto, deve-se ter em conta que os principais intervenientes na elaboração de projetos não são especialistas neste assunto e por conseguinte pretende-se que a ferramenta seja de simples aplicação. Não obstante que num futuro próximo, com o aprofundamento e uma maior utilização acerca da aplicação desta metodologia, a mesma possa vir a ser incorporado na Ferramenta.

Por outro lado, os sistemas de certificação de sustentabilidade, apesar de não terem o mesmo rigor que o ACV podem desempenhar um papel importante para a procura da sustentabilidade, desde logo devido à sua facilidade de compreensão e definição do desempenho em classes hierárquicas compreensíveis (DING, 2008) (FERREIRA, 2013). Este tipo de sistemas podem fornecer orientações fundamentais para que a construção consiga atingir as metas definidas pelo desenvolvimento sustentável (DING, 2008) Ainda segundo Haapio e Viitaniemi (2008), em muitos casos que se pretende caminhar para a sustentabilidade, o valor da classe final é fundamental, sendo esse um dos objetivos que pode condicionar muitas das decisões a tomar sobre qual o caminho a seguir. Por conseguinte, optou-se que a ferramenta fosse desenvolvida com base nos sistemas de certificação de sustentabilidade, mesmo considerando que estes não são tão precisos e rigorosos como a metodologia de ACV. Atualmente existe centenas deste tipo de sistemas, cada um com as suas valências distintas. Pretende-se que o sistema a incorporar na ferramenta seja amplamente utilizado no Brasil e, ao mesmo tempo, que tenha alguma abrangência internacional, podendo ser customizado em outros contextos, como por exemplo Portugal. Neste sentido, optou-se por utilizar o sistema Leadership in Energy and Environmental Design (LEED) como base ao desenvolvimento da Ferramenta pelo facto de ser um dos sistemas mais utilizados no Brasil e também internacionalmente. Importa referir que apesar de se ter utilizado este sistema na ferramenta, num próximo trabalho, é possível incorporar também o referencial técnico QAE do sistema AQUA, que juntamente com o sistema LEED é um dos mais utilizados no Brasil. 


\subsection{Seleção do Tipo de Edifícios Adoptado na Ferramenta}

Conforme exposto no capítulo 3, o referencial LEED a utilizar depende fundamentalmente do tipo de edifício que se pretende certificar. Com efeito, optou-se por utilizar na Ferramenta o referencial New Construction (LEED-NC) uma vez que é um dos sistemas mais utilizados, considerando a sua abrangência que pode ser adaptada a diferentes contextos, tais como edifícios residenciais de múltiplos pavimentos e edifícios de serviços. Relativamente à versão utilizada optou-se pelas versões v3.0 e v4.0. Sobre este aspecto importa referir que em Dezembro de 2013, a organização United States Green Building Council (USGBC) lançou a versão mais recente do LEED v4.0. No entanto, devido às dificuldades de implantação desta versão no Brasil, só será obrigatória a partir do final de 2016. Até lá a versão 3.0 estará em vigência. Deste modo a Ferramenta incorpora ambas as versões (3.0 e 4.0), no sentido de garantir a sua aplicabilidade tanto atualmente como num futuro próximo. Fica assim garantido os interesses dos futuros colegas e pesquisadores que pretendam utilizar a Ferramenta tanto para fins académicos como profissionais. No capítulo 3 desta dissertação expõem-se uma analise comparativa entre as duas versões.

\subsection{Seleção dos Documentos Normativos}

A fase dois do desenvolvimento da Ferramenta, conforme referido, está direcionada para os projetistas que intervêm nas principais especialidades de projeto (arquitetura, estruturas, instalações elétricas mecânicas e hidráulicas). Deste modo, e para garantir a qualidade técnica das soluções que serão incorporadas no projeto, é fundamental que as mesmas sejam baseadas em documentos normativos. Assim, para cada parâmetro do sistema LEED que se pretende atender, houve a necessidade de efetuar uma pesquisa bibliográfica para enquadrar as normas aplicáveis. Refere-se que os documentos normativos apenas entram na Fase 2 da ferramenta, para auxiliar a equipe de projeto na incorporação das melhores soluções técnicas no projeto. Em contraponto na Fase 1, vocacionada unicamente para o Gestor de Projeto, não foi tido em consideração os documentos normativos, admitindo que é da responsabilidade da equipe de projeto analisar as soluções construtivas a incorporar no projeto. O Gestor de Projeto terá a responsabilidade de gerir o projeto e, durante a realização deste, garantir que o mesmo cumpra os requisitos definidos em termos de sustentabilidade que se pretende alcançar. 
Deste modo, e para cada especialidade de projeto, foram tidos em conta vários textos normativos em função das diferentes especialidades de projeto. No capítulo 6, irá ser apresentado a relação dos documentos normativos em função de cada especialidade.

\subsection{Seleção do Software Adoptado na Ferramenta}

A Ferramenta foi desenvolvida com base na ferramenta informática MS Excel. Tal opção resulta do facto de ser um software amplamente usado e acessível tanto no meio académico como no mercado brasileiro e internacional. Acresce ainda que o MS Excel permite a organização optimizada das várias informações técnicas considerando a forma como a ferramenta se encontra estruturada.

Após esta explicação relativamente à metodologia adoptada na elaboração da ferramenta, no capítulo seguinte irá ser detalhado a forma como esta está estruturada, bem como o seu funcionamento. 


\section{CAPITULO 6 - FERRAMENTA PROPOSTA}

A ferramenta que se propõe apresentar, tem como objetivo criar uma abordagem, que de uma forma coordenada e integrada permita orientar o desenvolvimento de soluções sustentáveis ao longo das diferentes fases de desenvolvimento de um projeto. A ferramenta procura desmistificar a complexidade às vezes gerada em incluir medidas e soluções sustentáveis que se colocadas por si próprias e no momento exato não constituem um fator de incremento de entropia no seio da equipa projetista.

Por meio da correta aplicação desta ferramenta, é possível acompanhar as diferentes fases de um projeto de edifícios, desde o Estudo Preliminar, passando pelo Anteprojeto e Projeto Legal até ao Projeto de Execução, assumindo em qualquer altura os princípios de sustentabilidade assente no sistema de certificação LEED-NC New Constructions and Major Renovations e nos documentos normativos pertinentes.

Para melhor situar a compreensão do leitor sobre o desenvolvimento da ferramenta é importante considerar os seguintes aspetos (já mencionados anteriormente):

> Os sistemas de avaliação de sustentabilidade de edifícios podem desempenhar um papel importante na procura da sustentabilidade (DING, 2008) (FERREIRA, 2013).

> Os parâmetros e critérios definidos nestes sistemas devem ser levados em consideração logo na fase inicial de concepção de projeto, permitindo uma colaboração precoce entre as equipas de projeto e as questões de sustentabilidade que se pretendem alcançar (DING, 2008).

> Atualmente, um dos principais desafios passa por desenvolver e implementar uma metodologia sistemática que sirva de suporte ao processo de concepção de um edifício. Esta metodologia deve contribuir para o equilíbrio mais adequado entre as diferentes dimensões de sustentabilidade, sendo ao mesmo tempo prático, transparente e suficientemente flexível (BRAGANÇA, 2010).

De acordo com estes desideratos, o presente trabalho procurou desenvolver uma Ferramenta inovada que pretende ser um instrumento facilitador para a equipa projetista, permitindo não só disponibilizar informação técnica para auxiliar a tomada de decisão dos projetistas ao longo das várias etapas de desenvolvimento de um projeto, mas também, fornecer ao gestor do projeto um maior e mais eficiente controlo no que se refere à introdução de medidas e soluções sustentáveis em projeto. 
A procura da sustentabilidade de um edifício é da responsabilidade de todos os intervenientes do projeto. Com efeito, a ferramenta foi desenvolvida para interagir nas várias fases e nas várias especialidade de um projeto, auxiliando os principais intervenientes a trabalharem de maneira integrada. A tabela 6.1 representa um esboço inicial do que se pretende com a Ferramenta. Ou seja, para cada estágio do projeto, transmitir informação técnica com requisitos de sustentabilidade para os diferentes intervenientes do projeto. Há medida que o projeto evolui, desde o Estudo Preliminar até ao Projeto de Execução, é espectável que as informações técnicas evoluam para se adequarem aos níveis de desempenho pretendidos em cada estágio.

\begin{tabular}{|c|c|c|c|c|}
\hline & $\begin{array}{c}\text { Arquitetura e } \\
\text { Paisagismo }\end{array}$ & Estruturas & $\begin{array}{l}\text { Instalações } \\
\text { Hidráulicas }\end{array}$ & $\begin{array}{l}\text { Instalações } \\
\text { Mecânicas }\end{array}$ \\
\hline $\begin{array}{l}\text { Estudo } \\
\text { Preliminar }\end{array}$ & $\begin{array}{l}\text { Conectividade do } \\
\text { edifício à } \\
\text { comunidade, tais } \\
\text { como transporte } \\
\text { públicos e } \\
\text { amenidades locais; } \\
\text { optimização da } \\
\text { forma volumetria e } \\
\text { orientação }\end{array}$ & $\begin{array}{l}\text { No caso de edifícios } \\
\text { existentes - plano de } \\
\text { reaproveitamento de } \\
\text { elementos estruturais e } \\
\text { elementos interiores }\end{array}$ & $\begin{array}{c}\text { Definir } \\
\text { estratégias } \\
\text { para reduzir o } \\
\text { consumo de } \\
\text { água potável; } \\
\text { análise custo } \\
\text { benefício das } \\
\text { diferentes } \\
\text { soluções }\end{array}$ & $\begin{array}{c}\text { Parâmetros mínimos } \\
\text { de forma a garantir a } \\
\text { Qualidade do Ar } \\
\text { Interior; parâmetros } \\
\text { de conforto térmico } \\
\text { para os usuários do } \\
\text { edifício }\end{array}$ \\
\hline Anteprojeto & $\begin{array}{c}\text { Arquitetura } \\
\text { bioclimática; } \\
\text { promover a } \\
\text { iluminação e } \\
\text { ventilação natural; } \\
\text { conservar/restaurar } \\
\text { as áreas verdes }\end{array}$ & $\begin{array}{l}\text { Incluir materiais com } \\
\text { conteúdo reciclado, } \\
\text { recuperados ou } \\
\text { reutilizados, regionais, } \\
\text { rapidamente renováveis } \\
\text { e/ou certificados }\end{array}$ & $\begin{array}{l}\text { Determinar } \\
\text { volume de } \\
\text { águas pluviais } \\
\text { aproveitar; } \\
\text { determinar os } \\
\text { caudais de } \\
\text { cálculo }\end{array}$ & $\begin{array}{c}\text { Pré-dimensionamento } \\
\text { dos sistemas AVAC's } \\
\text { e ventilação; } \\
\text { utilização de sistemas } \\
\text { de energia renovável; } \\
\text { energia verde }\end{array}$ \\
\hline $\begin{array}{l}\text { Projeto } \\
\text { Legal }\end{array}$ & $\begin{array}{l}\text { Armazenamento e } \\
\text { coleta seletiva dos } \\
\text { resíduos } \\
\text { domésticos; } \\
\text { sistemas de } \\
\text { sombreamento nas } \\
\text { fachadas; } \\
\text { bicicletários }\end{array}$ & $\begin{array}{c}\text { Atualizar componentes } \\
\text { estruturais para } \\
\text { melhorar a eficiência } \\
\text { energética do edifício; } \\
\text { dimensionamento dos } \\
\text { elementos e } \\
\text { componentes da } \\
\text { edificação }\end{array}$ & $\begin{array}{l}\text { Dimensioname } \\
\text { nto do } \\
\text { reservatório, } \\
\text { traçado das } \\
\text { redes e } \\
\text { respetivos } \\
\text { componentes }\end{array}$ & $\begin{array}{c}\text { Simulação } \\
\text { computacional e } \\
\text { melhorar a eficiência } \\
\text { energética do edifício; } \\
\text { ajustar os níveis de } \\
\text { iluminação natural }\end{array}$ \\
\hline $\begin{array}{l}\text { Projeto de } \\
\text { Execução }\end{array}$ & $\begin{array}{l}\text { Materiais de alta } \\
\text { refletividade e/ou } \\
\text { vegetativos; } \\
\text { controlo interno de } \\
\text { produtos químicos } \\
\text { e poluentes } \\
\text { (COV's); } \\
\text { superfícies } \\
\text { permeáveis }\end{array}$ & - & $\begin{array}{l}\text { Torneiras de } \\
\text { baixo fluxo; } \\
\text { sistema de } \\
\text { "first-flush"; } \\
\text { especificações } \\
\text { de manutenção }\end{array}$ & $\begin{array}{l}\text { Equipamentos de } \\
\text { baixo consumo } \\
\text { energético que não } \\
\text { possuam CFC's, } \\
\text { HCFC's e Halons; } \\
\text { monitorização e } \\
\text { verificação dos } \\
\text { sistemas }\end{array}$ \\
\hline
\end{tabular}

Tabela 6.1: Esboço inicial da ideia para posterior desenvolvimento da ferramenta

Por outro lado e conforme analisado no estado de arte desta dissertação, a utilização de processo de concepção integrado é fundamental para se atingirem níveis de sustentabilidade superior à prática. No entanto este tipo de abordagem acresce 
responsabilidades adicionais tanto para a equipe projetista como para o coordenador do projeto, exigindo também um nível de comunicação mais elevado entre os mesmos. Considerando as diferentes funções e responsabilidades da equipa projetista e do coordenador de projeto, a ferramenta desmembrou-se em duas fases distintas: uma destinada a auxiliar o Gestor de Projeto no controlo e coordenação do mesmo; a segunda fase destinada a auxiliar a equipe projetista no desenvolvimento de soluções e sistemas construtivos ao longo do ciclo de vida de evolução de um projeto. No subcapítulo seguinte irá ser detalhada cada uma destas duas fases. Pensa-se que, a forma como a ferramenta se encontra estruturada irá auxiliar no desenvolvimento do projeto, assumindo em qualquer altura os contributos de Projeto Integrado.

Salienta-se que a Ferramenta deve ser aplicada numa fase inicial do projeto, preferencialmente logo no programa base, de forma a orientar as fases subsequentes do mesmo, permitindo assim, um balanço equilibrado entre o pretendido pelo Promotor de obra e os níveis de sustentabilidade a serem considerados. Adicionalmente, pretende-se que a Ferramenta não apresente dificuldades acrescidas à equipa projetista, apenas a disponibilização dos elementos necessários no momento preciso.

Por fim, a Ferramenta é susceptível de sofrer modificações e atualizações sempre que tal se justifique, na sequência de alterações legais ou normativas, do sistema de certificação ou para se adaptar à evolução tecnologia dos materiais, equipamentos e processos construtivos.

\subsection{Organização da Ferramenta}

A forma como se organiza a ferramenta, concretiza os principais aspetos a ter em consideração ao longo das várias fases do projeto, para que de um modo objetivo e concreto sejam abordados determinados parâmetros que, atualmente não são considerados de uma forma evidente à luz da sustentabilidade.

Neste contexto, os parâmetros considerados são baseados nas boas práticas, tanto ao nível da arquitetura, como ao nível das principais especialidades da engenharia, para que uma vez desenvolvidos e corretamente aplicados aos edifícios permita que estes alcancem uma boa qualidade arquitetônica de conforto e salubridade para os utilizadores e um bom desempenho ao nível da construção sustentável. A Ferramenta 
permite também auxiliar o desenvolvimento do projeto de forma a ser certificado pelo sistema LEED (certificado, prata, ouro ou platina).

No que se refere ao faseamento do projeto, de acordo com a norma brasileira NBR 13.531/1995, não foram incluídas na ferramenta as etapas iniciais da norma, nomeadamente o levantamento, o programa de necessidades e o estudo de viabilidade. Admite-se que as decisões mais relevantes em termos de sustentabilidade, nomeadamente o tipo de produto, características e nível de desempenho ocorram nas seguintes fases: i) estudo preliminar; ii) anteprojeto; iii) projeto legal; iv) projeto de execução. Desta forma a ferramenta incide apenas nestas quatro etapas.

Por outro lado, para incluir soluções de sustentabilidade em projeto, é necessário que as mesmas estejam direcionadas para aqueles que são os principais intervenientes. Deste modo, a Ferramenta encontra-se estruturada em função das diversas especialidades do projeto, igualmente definidas pela norma NBR 13.531/1995: i) arquitetura; ii) equipamentos e instalações de água e esgotos; iii) equipamentos e instalações mecânicas e elétricas; iv) sistema estrutural; e v) gestão integrada de resíduos.

A forma como a ferramenta foi desenvolvida considerar-se-á duas fases bem distintas, nomeadamente:

Fase 1: Desenvolvimento da estrutura de gestão, direcionada unicamente para o Gestor de Projeto;

$>$ Fase 2: Desenvolvimento de um conjunto de processo, direcionada unicamente para a equipe projetista.

Na Fase 1, procurou-se que a ferramenta consiga auxiliar o Gestor de Projetos para efetuar a monitorização e controlo dos objetivos do projeto, desde a fase inicial até à sua conclusão, fornecendo um conjunto de indicadores necessários à sua gestão. A Ferramenta permite ainda auxiliar o Gestor na forma como estes indicadores evoluem ao longo de todo o projeto e, através desta análise, identificar as tendências do mesmo e eventuais desvios, permitindo que no desenrolar do restante projeto estes desvios sejam identificados e corrigidos.

$\mathrm{Na}$ fase 2, procurou-se elaborar de um conjunto de processos, que se encontram direcionados para os principais elementos da equipe de projeto responsáveis pelas atividades técnicas de edificação e seus elementos, instalações e componentes. O 
objetivo desta segunda fase consiste em auxiliar a equipa projetista na incorporação das melhores soluções, tecnologias e sistemas construtivos com requisitos de sustentabilidade capazes de cumprir com as condições pré-estabelecidas com o Promotor de obra, já que este é o responsável pela encomenda das operações e pela celebração do respetivo contrato de adjudicação.

Estas duas fases foram desenvolvidas em momentos diferentes durante a dissertação e de forma conjunta constituem a Ferramenta que se propõe apresentar. Seguidamente detalhar-se-á cada uma delas.

\subsubsection{Fase 1 - Desenvolvimento da Estrutura de Gestão}

O desenvolvimento do projeto exige o estabelecimento de metas de desempenho e a avaliação do mesmo deve fazer parte de um processo rigoroso, para além de uma melhor compreensão das interações entre os sistemas da edificação e as soluções construtivas de um projeto sustentável (KEELER; BURKE, 2010). Deste modo a Fase 1 foi estruturada de maneira a controlar e acompanhar a evolução das várias soluções construtivas elaboradas pela equipe de projeto em função de cada especialidade e em cada etapa do projeto. Mais ainda, será possível auxiliar o Gestor a identificar, discutir e apoiar a implementação de soluções para correção de desvios verificados. A figura 6.1 representa, esquematicamente, a forma como a Ferramenta se encontra organizada.

A forma como se encontra ordenada a Fase 1 da Ferramenta, permite ao Gestor utilizar a informação disponibilizada e controlar o andamento do projeto, bem como propor alterações ao seu planeamento de acordo com as metas estabelecidas pelo o Promotor de obra. 


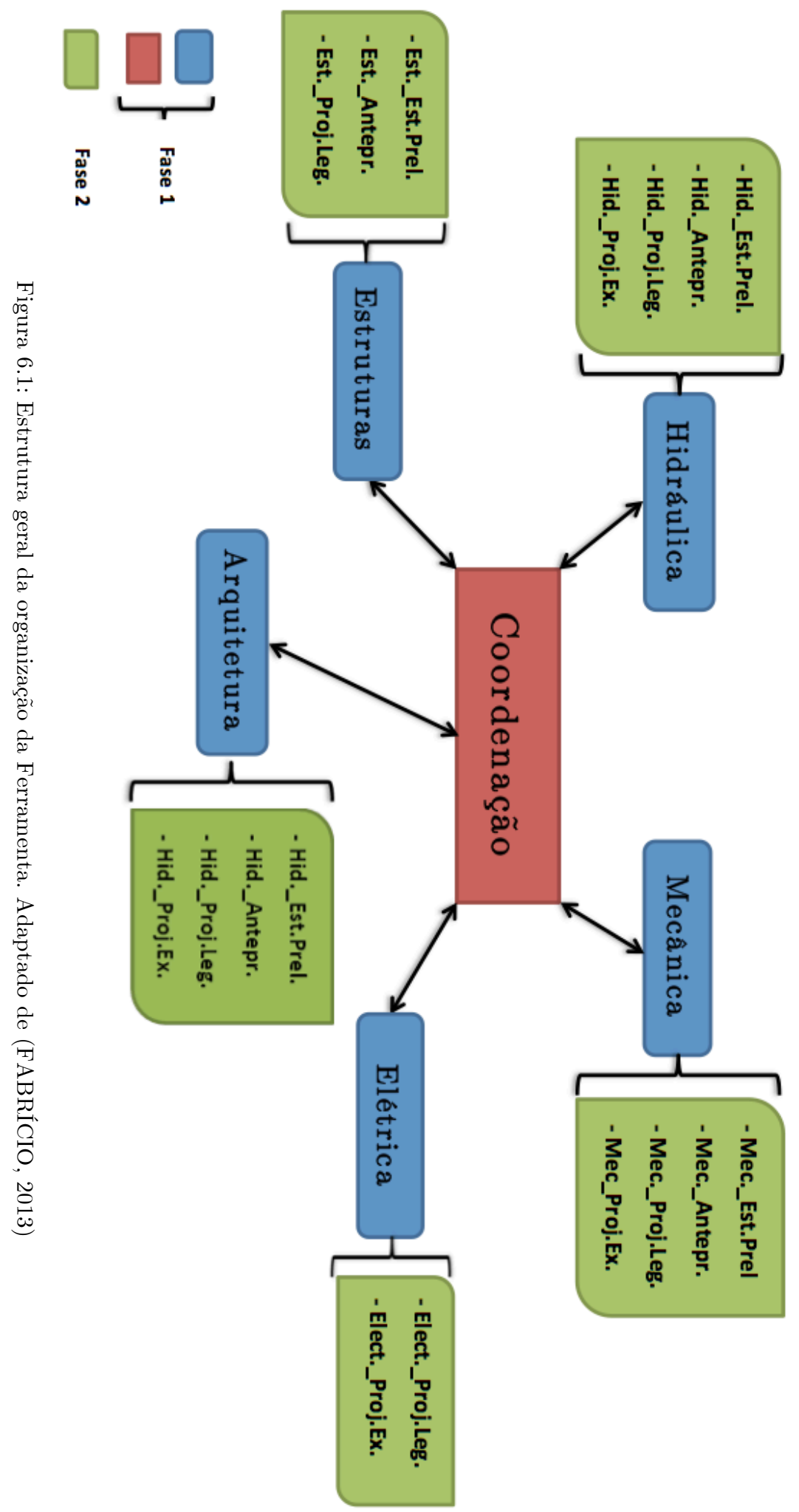


Pela análise da figura 6.1 é possível constatar que para cada etapa de projeto é possível efetuar a coordenação do mesmo em função das diferentes especialidades (arquitetura, estruturas, elétrica, hidráulica e mecânica), identificado pela cor vermelha e azul que corresponde à Fase 1. Ou seja, será disponibilizado diferentes tipos de informação de acordo com a especialidade em questão. Através da mesma figura constata-se a existência dos processos, identificados com a cor verde que correspondem à Fase 2 da Ferramenta que será devidamente explicado no próximo subcapítulo.

A materialização deste pressuposto, foi elaborado com base na ferramenta de cálculo do Microsoft Excel que, conforme já foi explicado, encontra-se estruturada em função das principais especialidades que compõe o projeto. Por sua vez, e conforme elucidado na figura 6.2, cada especialidade encontra-se subdividida em função das várias etapas de projeto, permitindo assim que em cada etapa se disponibilizem diferentes indicadores. 


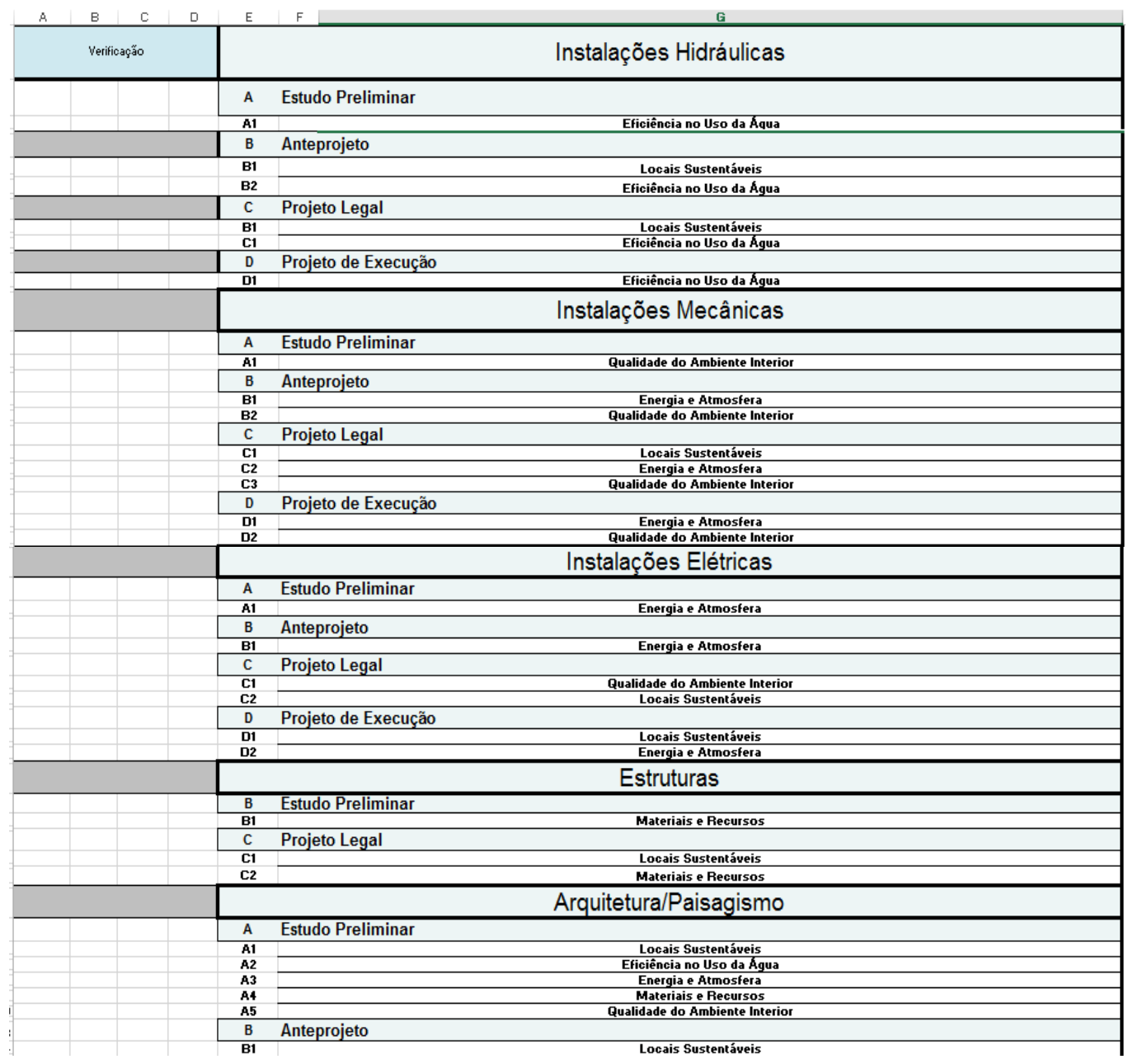

Figura 6.2: Parte da estrutura geral da Ferramenta que compõe a Fase 1

Dentro de cada etapa de projeto (estudo preliminar, anteprojeto, projeto legal e projeto de execução) existe um conjunto de indicadores, que correspondem a linhas de orientação que, seguidas cronologicamente irão permitir ao Gestor uma eficiente coordenação de projeto. As linhas de orientação correspondem a indicadores de sustentabilidade que se encontram devidamente estruturados e direcionados para auxiliar na monitorização e controlo dos objetivos do projeto por forma a que este cumpra determinados requisitos de desempenho em função de cada especialidade.

Importa referir que a Ferramenta está estruturada de acordo com os pressupostos de processo de concepção integrado, ou seja, envolve a participação tanto da arquitetura como das principais especialidades da engenharia logo nas etapas iniciais do mesmo. Por este motivo a ordem com que aparece a espacialidade de hidráulica no inicio e 
arquitetura no fim, conforme se verifica na figura 6.2 , em nada altera a aplicabilidade da ferramenta, uma vez que o processo de concepção integrado envolve uma equipe de projeto com uma maior gama de técnicos especialistas desde as primeiras fases de desenvolvimento de projeto. Esta filosofia contrasta com processo tradicional em que se inicia com arquiteto para desenvolver um programa e de seguida realiza a concepção do projeto com auxílio dos engenheiros.

Por sua vez, e de forma a organizar os indicadores que integram a Fase 1 da ferramenta, os mesmos encontram-se distribuídos em função das cinco áreas gerais avaliadas pelo LEED-NC (locais sustentáveis, eficiência no uso de água, energia e atmosfera, materiais e recursos, e qualidade do ambiente interior). A figura 6.3 e 6.4 ilustram a forma como os indicadores estão dispostos na ferramenta.

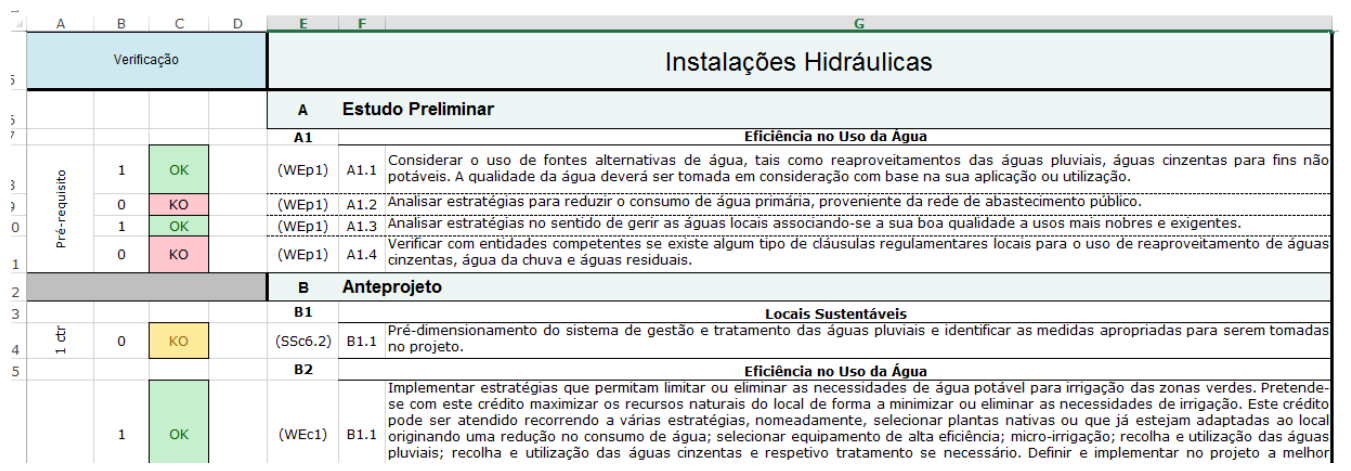

Figura 6.3: Pormenor da ferramenta; alguns indicadores na especialidade instalações hidráulicas 


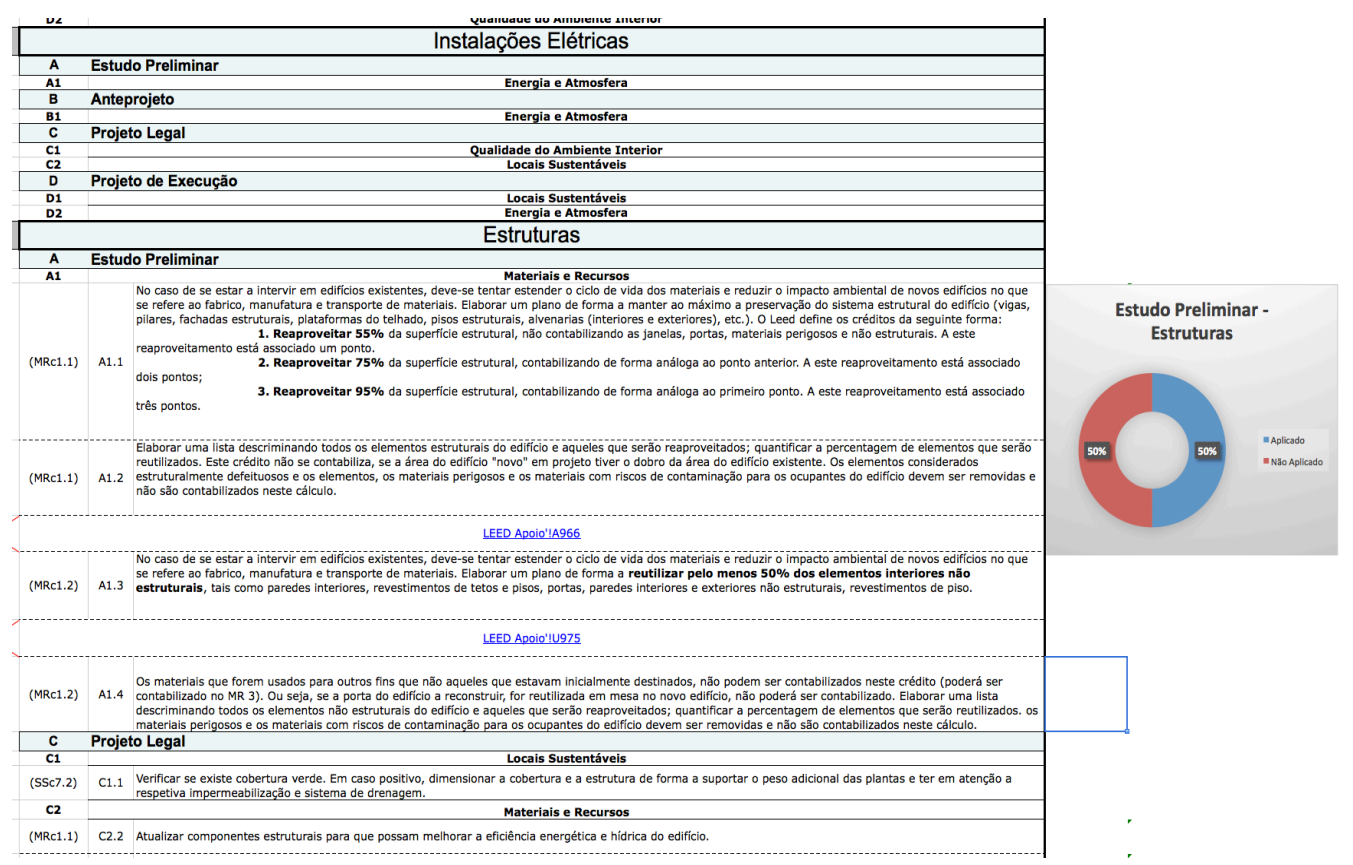

Figura 6.4: Pormenor da ferramenta; alguns indicadores na especialidade de estruturas

Foram também incluídos na Ferramenta, através de uma nova planilha, a versão 4.0 do LEED-NC, que está estruturada de forma análoga à versão 3.0. No entanto procedeu-se à atualização dos critérios que o compõe, incluindo a nova área Localização e Transporte.

De forma sucinta, a Fase 1 da Ferramenta apresenta as seguintes características:

- Cada indicador encontra-se devidamente identificado em função da categoria e respetivo crédito associado no sistema LEED. Por exemplo as categorias Locais Sustentáveis são designadas de "SS"; Energia e Atmosfera "EA". Para cada categoria encontra-se associado o respetivo crédito (c) e pré-requisito (p). Desta maneira consegue-se efetuar eventuais atualizações ou alterações à ferramenta de uma maneira mais eficiente;

- Possuí um sistema de verificação de conformidade (canto superior esquerdo da figura 6.3). Assim, dependendo se o indicador estiver a ser introduzido ou não no projeto, deverá ser colocado um "1" ou "0" respetivamente. A ferramenta encontra-se programada para apenas aceitar um destes dois valores, na coluna B. Na coluna C, faz a validação automaticamente ("OK" - se estiver a ser implementado; "KO" - se não estiver a ser implementado). Está igualmente associado na coluna $\mathrm{C}$, um código de cores, de maneira a que aparecerá a cor "verde" se o crédito estiver implementado; "amarelo" se o crédito não for 
implementado ou "vermelho" se o mesmo for um pré-requisito. Esta verificação de conformidade irá auxiliar o Gestor na monitorização dos vários requisitos de sustentabilidade que estão a ser incorporados no projeto;

- Na coluna mais à direita, e conforme ilustrado na figura 6.4, estão associados gráficos, que proporcionam ao Gestor uma melhor visualização do número de indicadores que estão a ser implementados no projeto. Os gráficos encontramse desenvolvidos em função das várias especialidade e faseamento do projeto. Deste modo, para cada etapa do projeto e de acordo com a especialidade em questão, é possível quantificar o número de indicadores que estão a ser incluídos;

- No final da ferramenta, e conforme ilustrado na figura 6.5, foi incluído um gráfico radar, em que cada vértice indica o que está a ser incluído ou não no projeto em cada categoria LEED. Todos estes gráficos encontram-se programados para gerarem valores automaticamente em função do número de indicadores que estão a ser ou não incluídos no projeto. Permite-se, desta forma, uma melhor visualização do número de indicadores que foram implementados aquando o término do projeto;

- Por fim foi desenvolvido, uma nova planilha com informações adicionais. Esta nova planilha tem como objetivo auxiliar o Gestor na verificação de alguns indicadores que possam suscitar dúvidas relativamente aquilo que se pretende incluir no projeto. Nestes casos, o indicador possuí uma hiperligação que direciona para a célula correta da planilha de apoio permitindo ao Gestor visualizar o que se prende introduzir no projeto. Salienta-se que só alguns indicadores possuem esta caraterística.

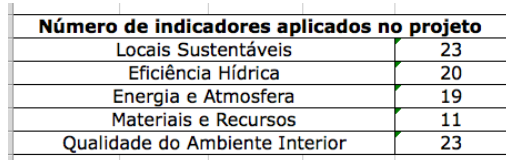

Número de indicadores não aplicados no projeto

Número de indicadores nấo Eficiência Hídrica Energia e Atmosfera Materiais e Recursos Qualidade do Ambiente Interior

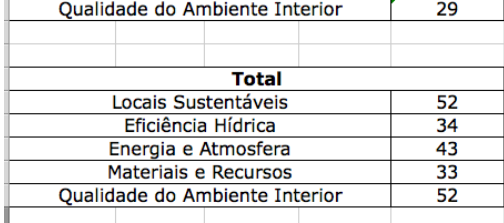

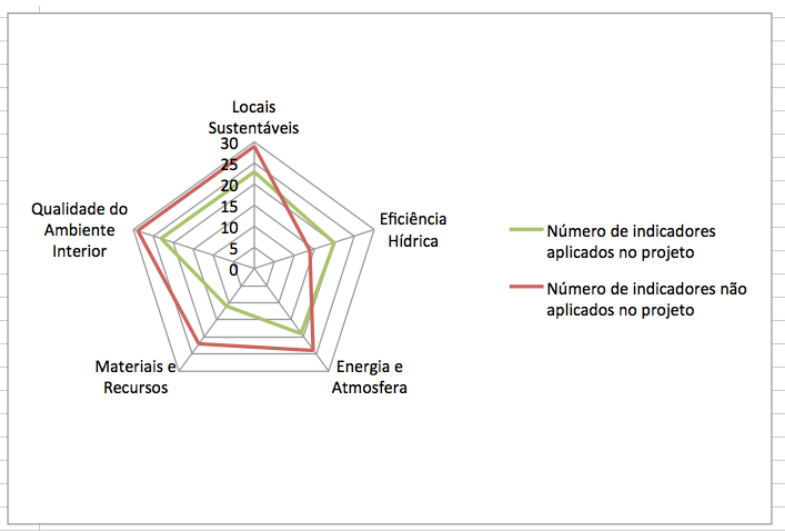

Figura 6.5: Exemplo da contabilização final do número de indicadores que estão a ser ou não implementados no projeto 
A Fase 1 pressupõem que as exigências legais são cumpridas e que as mesmas são adoptadas como requisitos essenciais mínimos nas diferentes especialidades consideradas. Na realidade, as exigências normativas foram levadas em consideração na Fase 2 do desenvolvimento desta Ferramenta de maneira a que as soluções construtivas definidas pelos projetistas atendam às conformidades normativas. Deste modo, a ferramenta pressupõem que é da responsabilidade da equipe de projeto analisar e adoptar as melhores soluções e sistemas construtivos que estejam adequados em termos normativos; o Gestor tem a responsabilidade de acompanhar, monitorar e controlar a evolução do projeto, garantindo que o mesmo cumpra com os requisitos definidos pelo Promotor da obra em termos de sustentabilidade que se pretende alcançar.

\subsubsection{Fase 2 - Desenvolvimento dos Processos}

O desenvolvimento desta segunda fase, teve como objetivo o desenvolvimento de um conjunto de processos que permita auxiliar a equipe projetista na definição de soluções, tecnologias e métodos construtivos como requisitos de sustentabilidade desde o inicio de concepção do projeto até à sua conclusão. Neste sentido as informações definidas na Fase 1 serviram de base para a elaboração dos processos, que se encontram incorporados na mesma planilha de Excel. No entanto o nível de informação é mais detalhado pois foram incorporados os requisitos normativos necessários para atender às necessidades das soluções construtivas. Os processos incorporam várias diretrizes normativas que foram incluídas em função de cada especialidade de projeto. Deste modo os processos estão devidamente atribuídos para cada especialidade de projeto.

Por outro lado, cada interveniente é responsável pelo processo que lhe está associado. É igualmente conveniente que o Gestor do Projeto sirva de intermediário entre aquilo que é pretendido pelo Promotor de obra, em termos de sustentabilidade para a construção, e as metas de projeto que se pretendem alcançar. Só assim a equipe projetista tem a perfeita noção dos indicadores que se pretendem introduzir no projeto, assumindo a responsabilidade de elaborar a melhor solução construtiva para atingir as respetivas metas. Obviamente que para cada solução construtiva existe sempre uma certa interligação entre as várias especialidades. Deste modo, e conforme se pode verificar no mapa de processos (figura 6.6), os processos encontram-se interligados permitindo que a equipe de projeto trabalhe de maneira integrada no detalhamento das soluções construtivas. Há medida que o projeto evolui, o nível de 
detalhe das soluções construtivas vai aumentando gradualmente de modo a abranger todos os créditos e pré-requisitos definidos no sistema LEED-NC, bem como os documentos normativos que se façam pertinentes.

$\mathrm{Na}$ Fase 2, inicialmente estava previsto o desenvolvimento de fichas de registo em vez dos atuais processos. No entanto as fichas de registo mostraram-se ineficientes na forma como a informação se relacionava entre os vários projetistas, não promovendo o fluxo de informação e comunicação entre os mesmo. Conforme foi visto no estado de arte desta dissertação um dos problemas identificados para aumentar os níveis de desempenho na construção sustentável, bem como no desenvolvimento do projeto integrado, torna-se necessário aumentar e melhorar os níveis de comunicação entre os vários projetistas, ou seja, pretende-se um fluxo de informação eficiente. Deste modo, as fichas de registo mostram-se obsoletas para estes fins.

Para contornar este problema optou-se por substituir as fichas de registo pelo desenvolvimento de um conjunto de processos, que se encontram interligados de maneira a aumentar e melhorar não só a comunicação entre os projetistas, mas também a forma como estes se relacionam. Permite-se assim que, por meio de partilha de ideias e opiniões se criem sinergias, possibilitando incorporar no projeto soluções construtivas visando integrar as necessidades das várias partes interessadas. Há medida que o projeto vai evoluindo as atividades técnicas definidas no projeto acompanham a evolução aumentando o nível de detalhe em cada fase. A figura 6.6 representa a forma como os processos se encontram interrelacionados, em função das várias especialidades de projeto e das várias fases do mesmo. 
$\breve{\infty}$

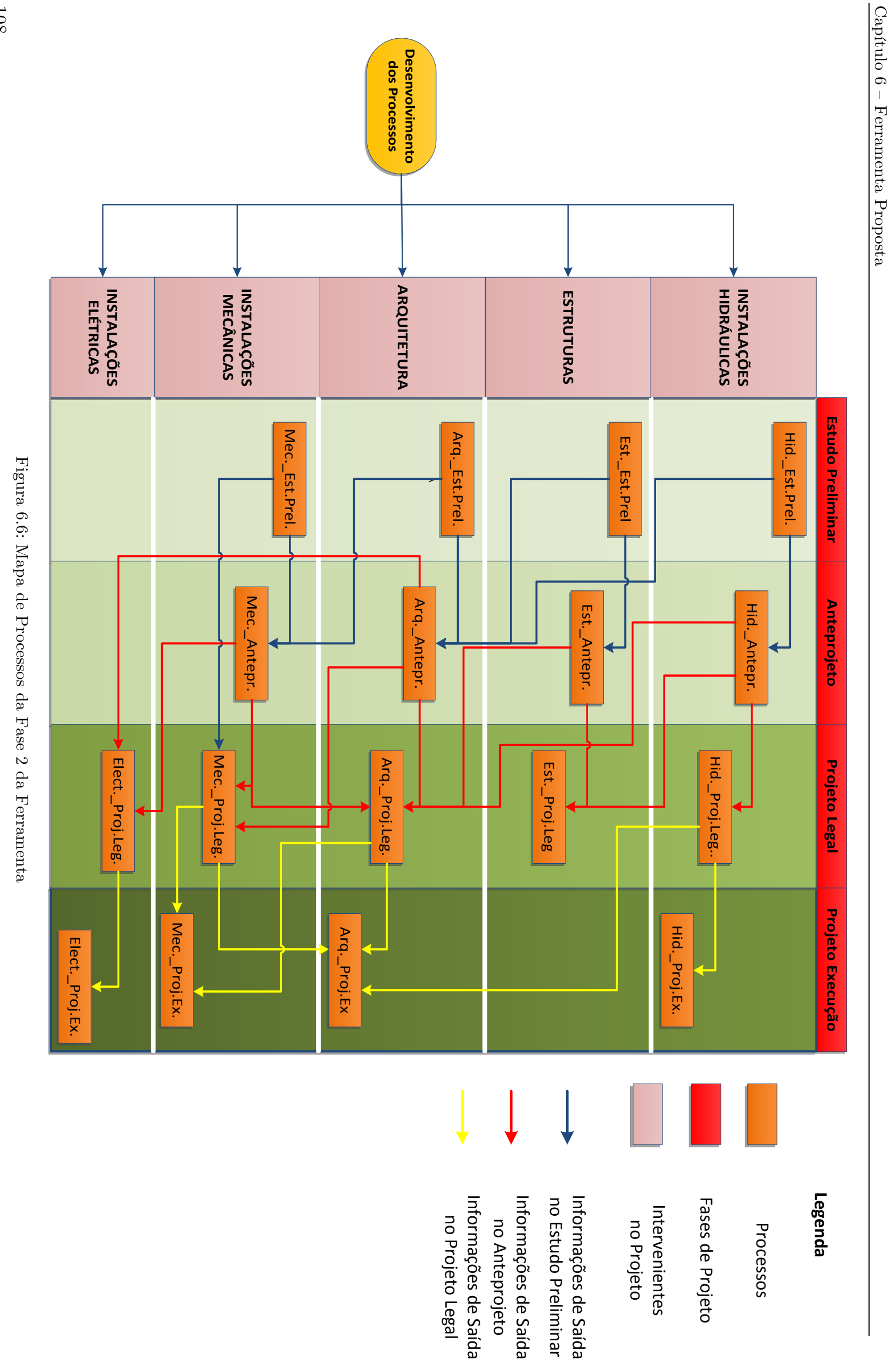


A ligação entre a Fase 1 e a Fase 2 foi crucial no desenvolvimento desta Ferramenta, um vez que tem de existir uma grande compatibilidade nas informações que compõem ambas as fases. Na realidade, as informações disponibilizadas na Fase 2 veiculadas à equipe projetista tem de estar em perfeita consonância com as informações disponibilizadas na Fase 1 veiculada ao Gestor do projeto, caso contrario corria-se o risco da equipe projetista incorporar em projeto determinadas soluções construtivas e as mesmas não fossem validadas pelo Gestor. Admite-se, que a Fase 2 é mais exigente no decurso de implementação da Ferramenta uma vez que são diferentes os intervenientes e os cuidados associados na execução de cada processo.

Com efeito, e de acordo com a figura 6.6, o mapa de processos segue uma sequência lógica, começando logo no estudo preliminar que orienta as fases subsequentes do projeto por meio de documentos técnicos específicos. Em cada etapa do projeto estão previstos diferentes processos em função de cada interveniente, ou seja, no Estudo Preliminar o processo destinado ao arquiteto é necessariamente diferente do engenheiro civil, que por sua vez também é diferente do engenheiro mecânico. Permite-se assim que para cada etapa estejam previstos diferentes processos, originando tipos de informação distintos em função de cada especialidade. Seguidamente irá ser detalhado individualmente alguns deles, para que o leitor sinta uma maior facilidade em compreender a forma como se organizou cada um individualmente. Observando a figura 6.6 verifica-se que foram desenvolvidos 17 processos distintos, considerando diferentes tipos de conhecimento técnico necessário para cumprir com os objetivos de cada etapa de projeto em função de cada especialidade. Cada processo é único e a informação técnica que o compõe não é repetitiva.

Segundo a ISO 9000 define processo como "conjunto de atividades interrelacionadas ou iterativas que transforma entradas em saídas". Com base nesta definição os processos introduzidos foram estruturados contendo "informações de referencia a utilizar" (figura 6.7) que corresponde às entradas; "informações técnicas a produzir" (figura 6.8) que corresponde às atividades a realizar; e por fim "documentos técnicos a apresentar" (figura 6.9) que correspondem às saídas. 


\begin{tabular}{|l|l|}
\hline \multicolumn{1}{|c|}{ Entradas/Informações de referência a utilizar } & \multirow{2}{|c|}{ ID Origem } \\
\hline $\begin{array}{l}\text { WEp1/WEc2/WEc3: Informações técnicas relativamente às estratégias que irão ser introduzidas no projeto quanto à } \\
\text { redução do consumo de água para fins potáveis e para fins não potáveis, tais como o aproveitamento das águas } \\
\text { pluviais, cinzentas ou negras, levando em consideração os condicionamentos de impacto ambiental, económico e social. }\end{array}$ & 1 - Hid._Est.Prel. \\
\hline WEp1: Parâmetros de qualidade da água a aproveitar e condições de drenagem da rede pública. & 1 - Hid._Est.Prel. \\
\hline $\begin{array}{l}\text { WEp1/WEc2/WEc3: Identificação dos níveis de conforto pretendidos para os sistemas (ruídos, acessibilidade dos } \\
\text { sistemas, odores, etc.). }\end{array}$ & 1 - Hid._Est.Prel. \\
\hline $\begin{array}{l}\text { SSc5.1: Informações/registos indicando todos os elementos naturais do local (corpos de água, condições do solo, } \\
\text { ecossistemas, árvores, etc.) onde será desenvolvido o edifício. }\end{array}$ & 1 - Arq._Est.Prel. \\
\hline $\begin{array}{l}\text { SSc6.1/SSc6.2: Memorial descritivo e justificativo relevantes do Estudo Preliminar no que se refere às estratégias de } \\
\text { controle da qualidade e quantidade das águas pluviais. }\end{array}$ & 1 - Arq._Est.Prel. \\
\hline Normas técnicas pertinentes. & -
\end{tabular}

Figura 6.7: Informações de referência a utilizar na especialidade de hidráulica no Anteprojeto

\begin{tabular}{|c|c|c|}
\hline Atividades/Informações técnicas a produzir & Parâmetros LEED & Normas \\
\hline 1 - Aproveitamento de águas pluviais (WEC1/WEc2) & - & - \\
\hline $\begin{array}{l}\text { - A água não potável proveniente da captação da água pode ser utilizada em para limpeza de bacias sanitárias e } \\
\text { mictórios, para combate a incêndios e outros usos onde o requisito de potabilidade não se faça necessário. }\end{array}$ & WEc1/WEc2 & NBR 5626:1998 \\
\hline $\begin{array}{l}\text { - O sistema de cobertura deve ter capacidade para drenar a máxima precipitação possivel, evitando empoçamentos ou } \\
\text { extravasamentos para o interior da edificação habitacional ou quaisquer outros locais não previstos no projeto. }\end{array}$ & WEc1/WEc2 & NBR 15575:2013 \\
\hline - O fundo do reservatório deve ficar acima do nível de água máximo do lençol freático e da cota de inundação máxima. & WEc1/WEc2 & NBR 12217:1994 \\
\hline $\begin{array}{l}\text { - O nível do lençol freático pode ser rebaixado mediante drenagem e descarga por gravidade. A drenagem deve circundar } \\
\text { o fundo do reservatório a uma distância que garanta a estabilidade da estrutura e previna riscos de contaminação }\end{array}$ & WEc1/WEc2 & NBR 12217:1994 \\
\hline $\begin{array}{l}\text { - Determinar o volume de águas pluviais aproveitáveis para posteriormente se proceder ao dimensionamento do } \\
\text { reservatório. O volume de águas pluviais pode ser determinado através da seguinte equação: } \\
\text { [ V=P*A*C } \\
\text { Onde: } \\
\text { V-Volume anual, mensal ou diário de água das chuvas aproveitável; } \\
\text { P-Precipitação média anual, mensal ou diária; } \\
\text { A-Área de captação; } \\
\text { C-Coeficiente de escoamento superficial da cobertura; } \\
\text { n- Eficiência do sistema de captação, levando em conta o dispositivo de descarte de sólidos e "first flush" caso seja } \\
\text { utilizado }\end{array}$ & WEc1/WEc2 & NBR 15527:2007 \\
\hline $\begin{array}{l}\text { - Determinar os caudais de cálculo para se proceder ao dimensionamento do sistema de drenagem das águas pluviais. Os } \\
\text { caudais de cálculo podem ser determinados através da seguinte formula: } \\
\text { [ Q=I*A/60] } \\
\text { Onde: } \\
\text { Q-Caudal de cálculo }(1 / \mathrm{min} .) \\
\text { I- Intensidade pluviométrica }\left(\mathrm{mm} / \mathrm{h}=1 / \mathrm{h}^{*} \mathrm{~m} 2\right) \\
\text { A-Área de contribuição }(\mathrm{m} 2) \text {. }\end{array}$ & & \\
\hline 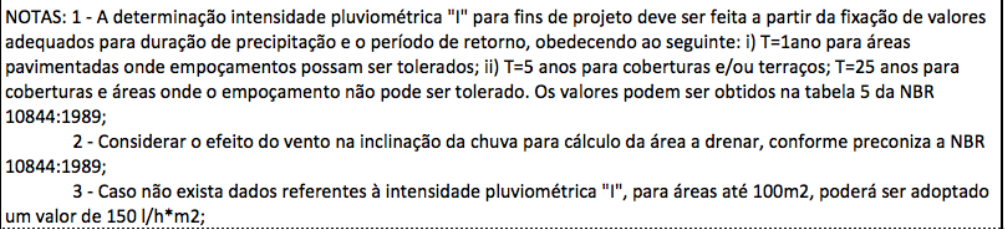 & WEc1/WEc2 & NBR 10844:1989 \\
\hline $\begin{array}{l}\text { - Realizar um pré-dimensionamento do reservatório, bem como a sua localização e principais componentes (tubagens, sistemas } \\
\text { de tratamento, etc.). }\end{array}$ & WEc1/WEc2 & NBR 15527:2007 \\
\hline & WEc1/WEc2 & NBR 15575:2013 \\
\hline
\end{tabular}

Figura 6.8: Atividades técnicas a produzir na especialidade de hidráulica no Anteprojeto

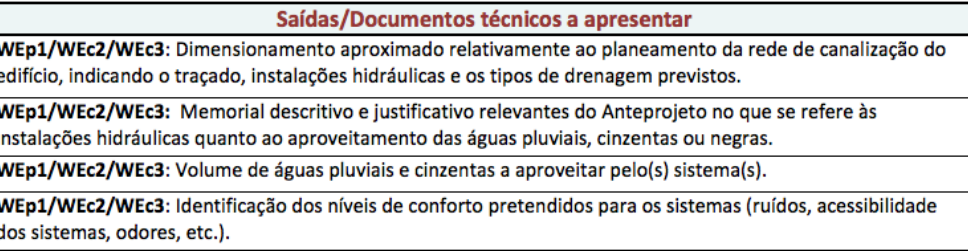

\begin{tabular}{|l|c|} 
& \multicolumn{1}{|c}{ ID destino } \\
\hline 1 - Hid._Proj.Leg. & 2 - Est._Proj.Leg. \\
\hline 1 - Hid._Proj.Leg. & - \\
\hline 1 - Hid._Proj.Leg. & - \\
\hline 1 - Hid._Proj.Leg. & -
\end{tabular}

Figura 6.9: Documentos técnicos a apresentar na especialidade de hidráulica no Anteprojeto 
De forma sucinta, cada processo apresenta as seguintes características:

- Cada processo é constituído por três partes. A primeira parte (figura 6.7) corresponde a um conjunto de documentos que contem "informações de referencia a utilizar". Estes documentos tem como objetivo auxiliar o projetista da respetiva especialidade no desenvolvimento de determinadas "atividades técnicas a produzir" permitindo assim incorporar no projeto soluções construtivas adequadas. Importa referir que as "atividades técnicas a produzir" (figura 6.8) não é mais que um conjunto de informações/indicadores que o projetista deverá ter em consideração no desenvolvimento de determinadas soluções construtivas. A terceira e última parte (figura 6.9) corresponde aos documentos técnicos que o projetista deve apresentar para validar as soluções construtivas que concebeu.

- Os documentos correspondentes às "informações técnicas a utilizar" estão devidamente identificados do processo que lhe deu origem. Por exemplo na Figura 6.7 verifica-se que os documentos que servem de referência ao Anteprojeto tem por base o Estudo Preliminar da especialidade de hidráulica (ID - Hid._Est.Prel.) e da arquitetura (ID - Arq._Est.Prel.). Estes documentos servirão de apoio para as atividades a desenvolver neste processo Hid._Antepr (Hidráulica Anteprojeto).

- As "informações técnicas a produzir" (figura 6.8), permite auxiliar o projetista a atingir os objetivos previstos nesta fase de projeto. Também nesta etapa cada indicador está devidamente identificado em função do parâmetro LEED que se pretende atender, bem como a referência normativa para garantir a qualidade técnica das soluções e sistemas construtivos que irão ser incorporadas no projeto. Tomando a figura 6.8 como exemplo, no que se refere à eficiência hídrica do edifício um dos parâmetros avaliados pelo LEED é reduzir o consumo de água potável da rede pública; neste sentido uma das estratégias pode passar pelo reaproveitamento das águas pluviais; torna-se então necessário nesta etapa de Anteprojeto determinar o volume de águas pluviais a aproveitar para se proceder à escolha das melhores soluções construtivas para sistema de drenagem e do reservatório. Por conseguinte, o correto dimensionamento do sistema de drenagem é especificado pela norma NBR 15.527:2007. Para cada parâmetro LEED a incorporar no projeto encontra-se devidamente apoiado em documentos normativos para garantir a qualidade da solução técnica que se pretende introduzir no projeto. Todos os 
processos identificados no mapa de processos que compõem a Fase 2 da Ferramenta encontram-se desenvolvidos de maneira análoga.

- Os "documentos técnicos a apresentar" (figura 6.9) constituem os resultados das soluções construtivas definidas no projeto. Estes documentos técnicos irão servir de documentos de referência/entrada noutros processos, podendo ser na mesma especialidade ou em outras que se verifique necessário. Por exemplo, caso o projetista introduza um sistema de aproveitamento de águas pluviais, de acordo com a figura 6.9, verifica-se que o dimensionamento do sistema de drenagem das águas pluviais tem como saídas o Projeto Legal na especialidade de hidráulica (ID Hid._Proj.Leg.) e estruturas (ID Est._Proj.Leg.), permitindo ao projetista de estruturas durante a etapa seguinte proceder ao correto dimensionamento que servirá de suporte aos elementos do sistema de aproveitamento de águas pluviais (tais como dimensionamento do suporte do reservatório). Analisando o mapa de processos da figura 6.6 constata-se exatamente isto, ou seja, o processo que corresponde à etapa de Anteprojeto para a especialidade de instalações hidráulicas apresenta a interligação ao processo de projeto legal nas especialidade de estruturas e hidráulicas.

Cada processo e de acordo com a especialidade em questão foram levados em consideração diferentes documentos normativos. As tabelas seguintes apresentam a relação entre eles. 


\section{Normas Aplicadas}

NBR 5626:1998 - Instalação predial de água fria

NBR 10844:1989 - Instalações prediais de águas pluviais

NBR 15527:2007 - Água da Chuva Aproveitamento de coberturas em áreas urbanas para fins não potáveis

NBR 13969:1997 - Tanques Sépticos - Unidades de Tratamento Complementar e disposição final dos efluentes líquidos

Instalações

Hidráulicas

NBR 12217:1994 - Projeto de Reservatório de Distribuição de água para abastecimento público

NBR 8160:1999 - Sistemas Prediais de esgoto sanitário - projeto e execução

ETA 0107 - Sistemas de Aproveitamento de Águas Pluviais em Edifícios

ETA 0905 - Sistemas de Reaproveitamento e Reciclagem de Águas Cinzenta

Tabela 6.2: Normas introduzidas nos processos na especialidade de Instalações Hidráulicas

\section{Normas Aplicadas}

NBR 15575:2013 - Norma de Desempenho de Edifícios Habitacionais.

NBR 15220:2008 - Desempenho Térmico das Habitações

Deliberação Normativa COPAM n 160/ 2010

ASHRAE 62.1-2007 - Ventilation for Acceptable Indoor Air Quality

ASHRAE 90.1-2007 - Energy Standard for Buildings Except Low-Rise Residential Buildings

Instalações

Mecânicas

EN 779:2012 - Particulate Air Filters for General Ventilation Determination of the Filtration Performance

EN 15251:2007 - Indoor environmental input parameters for design and assessment of energy performance of buildings addressing indoor air quality, thermal environment, lighting and acoustics

ASHRAE 55-2013 - Thermal Environmental Conditions for Human Occupancy

ISO 7730:2005 - Ergonomics of the thermal environment, Analytical determination and interpretation of thermal comfort

Tabela 6.3: Normas introduzidas nos processos na especialidade de Instalações Mecânicas 


\begin{aligned} & \multicolumn{2}{|l}{$\begin{array}{l}\text { Normas Aplicadas } \\ \text { NBR 10844:1989 - Instalações prediais de águas pluviais } \\ \text { NBR 15575:2013 - Norma de Desempenho de Edifícios Habitacionais }\end{array}$} \\ & \hline Estruturas $\begin{array}{l}\text { NBR 15220:2008 - Desempenho Térmico das Habitações } \\ \text { NBR ISO 14021:2013 - Rótulos e declarações ambientais. } \\ \text { Autodeclarações ambientais }\end{array} \\ &$\hline NBR 15575:2013 - Norma de Desempenho de Edifícios Habitacionais. \\ & \hline e Paisagismo \end{aligned}

Tabela 6.4: Normas introduzidas nos processos das especialidade de estruturas, arquitetura e paisagismo e instalações elétricas 


\section{CAPÍTULO 7 - CONCLUSÕES}

Neste capítulo são apresentadas as conclusões mais proeminentes deste trabalho. Em primeiro lugar serão avaliados os objetivos a que o pesquisador se propôs inicialmente a desenvolver; de seguida são expostas as contribuições deste trabalho para a comunidade científica e para os projetistas; por fim são referidas algumas recomendações para desenvolvimento de trabalhos de investigação futuros.

Durante o estado de arte desta dissertação foi destacado a importância do desenvolvimento sustentável dentro do contexto da industria da construção, bem como as principais limitações para que se atinja níveis de desempenho superiores à prática. Considerando esta necessidade, foi desenvolvido uma ferramenta que pretende criar uma abordagem inovadora que, de forma coordenada e integrada, permita orientar o desenvolvimento de soluções sustentáveis ao longo das diversas etapas de um projeto (Estudo Preliminar, Anteprojeto, Projeto Legal e Projeto de Execução).

\subsection{Avaliação da Realização dos Objetivos Propostos}

Analisando os objetivos propostos no início deste trabalho, conclui-se que os mesmos foram atingidos, quanto ao desenvolvimento de uma ferramenta de apoio à elaboração de projetos de edifícios sustentáveis, de acordo com os parâmetros LEEDNC. Inicialmente estava previsto apenas a introdução da versão 3.0 do LEED na ferramenta. No entanto, e de forma a garantir a sua aplicabilidade num futuro próximo optou-se por adicionar a versão 4.0 na ferramenta.

Em termos de pesquisa bibliográfica sobre o tema, existe um vasto leque de informação disponível, incluindo internacional, abordando a temática da gestão de projetos e metodologias de avaliação de sustentabilidade de edifícios. Por meio de análise da informação tentou-se desenvolver uma ferramenta que sirva de suporte ao processo de concepção de um edifício, permitindo que este obtenha um equilíbrio mais adequado entre as diferentes dimensões de sustentabilidade, sendo ao mesmo tempo prático, simples de utilizar e suficientemente flexível. Vem por instantes a velha máxima da gestão já professada em vários momentos - KISS "Keep It Smart and Simple". 
O desenvolvimento da ferramenta passou por um conjunto de etapas, que foram seguidas cronologicamente pela seguinte ordem:

- Elaborar uma pesquisa e analise bibliográfica sobre as técnicas de gestão integrada de projeto e das metodologias de apoio à avaliação da sustentabilidade dos edifícios;

- Analisar a sequência de evolução de projeto e identificar quais as variáveis que permitam ao gestor de projeto um maior e mais eficiente controlo no que se refere à introdução de soluções sustentáveis na indústria da construção de edifícios;

- Com recurso ao MS Excel, desenvolver uma ferramenta de apoio à gestão integrada, permitindo ao gestor do projeto acompanhar e monitorizar o andamento do projeto desde a fase inicial até a sua conclusão, de forma a identificar, em cada etapa, os requisitos de sustentabilidade que estão sendo introduzidos;

- Levantamento e análise de documentos normativos (nacionais e internacionais) relacionados com a sustentabilidade na construção;

- Identificar e compreender as principais fases e responsabilidade no desenvolvimento de projetos de acordo com as várias especialidades de projeto, bem como a forma como é efetuada a compatibilização e coordenação entre as várias especialidades;

- Adicionar à Ferramenta um conjunto processos que permita orientar os projetistas para soluções, tecnologias e sistemas construtivas com requisitos de sustentabilidade com base em documentos normativos e no sistema LEED-NC versão 3.0 e versão 4.0 .

\subsection{Contribuições para a Comunidade Científica e para os Projetistas}

Apesar de algumas limitações identificadas no capítulo anterior, considera-se que a presente dissertação contribuiu de forma positiva para a comunidade científica e para as empresas de projeto que atuam nesta área.

Ao longo dos últimos anos tem-se verificado um aumento significativo do interesse da pelo tema da construção sustentável, cada vez mais atual. Com a realização deste trabalho espera-se que o mesmo possa ser um contributo para a comunidade 
científica, fornecendo uma perspetiva inovadora no modo como conciliar a gestão de projetos com a sustentabilidade no ambiente construído.

Para além disto, espera-se igualmente que a ferramenta sirva de instrumento facilitador para as equipes projetistas, facilitando a integração em projeto de medidas e sistemas construtivos com requisitos de sustentabilidade.

\subsection{Trabalhos Futuros}

Tratando-se de uma investigação com a duração ideal de dois anos, alguns aspetos não foram focados na presente dissertação. Deste modo, apresentam-se de seguida alguns tópicos que poderão servir de guia de oportunidades para a realização de trabalhos futuros:

- A presente ferramenta apenas engloba um sistema de avaliação de sustentabilidade de edifício, o sistema LEED. Deste modo, uma das oportunidades de trabalhos futuros consiste em incorporar outros sistemas, desde logo o sistema AQUA que, juntamente com o LEED é um dos mais usados no Brasil;

- Calibrar e optimizar a ferramenta por meio de casos práticos. A aplicação da mesma a um caso real, de preferência numa fase inicial do seu desenvolvimento de um projeto, para garantir a inclusão de todas as variáveis. 


\section{REFERENCIAS BIBLIOGRÁFICAS}

ASSOCIAÇÃO BRASILEIRA DE NORMAS TÉCNICAS. NBR 13531. Elaboração de projetos de edificações - atividades técnicas, p.10 1995.

NBR 15113. Resíduos sólidos da construção civil e resíduos inertes Aterros - Diretrizes para projeto, implantação e operação, p. 12, 2004.

NBR ISO 14040. Gestão ambiental - Avaliação do ciclo de vida princípios e estrutura, 2009. 10.

AGENDA 21 brasileria. Agenda 21 brasileira; ações prioritárias, p. 138, 2004.

AIA. Integrated Project Delivery: A guide, 2008.

AIACC. Integrated Project Delivery: An updated working definition: The American Institute of Architects, California Council, v. 3, 2014.

ALMEIDA, F. Os Desafios da Sustentabilidade, Elsevier, 2007.

AMADO, M.; FERREIRA, A. B. Contrução do edifício sustentável - contribuição para um processo operativo. Congresso de Inovação na Construção Sustentável, 2010.

ANDERY, P.; CAMPOS, C.; ARANTES, E. Desenvolvimento de um termo de referência para o gerenciamento de projetos integrados em uma instituição pública. Gestão e Tecnologia de Projetos, São Carlos, 2012.

AQUA. Edifícios Habitacionais - 2013 versão 2: Fundação Vanzolini e CERQUAL, p. 122, 2013.

BEN. Balanço Energético Nacional. Brasil. 2014.

BRAGANÇA, L.; MATEUS, R. Sustentabilidade de Soluções Construtivas. [S.1.]: Congresso sobre construção sustentável, 2004.

BRAGAnÇA, L.; MATEUS, R. Avaliação do Ciclo de Vida dos Edifícios Impacte Ambiental de Soluções Construtivas, 2011.

BRAGANÇA, L.; MATEUS, R. Análise do Ciclo de Vida de Construções Metálicas. Universidade do Minho - Escola de engenharia, 2012.

BRAGANÇA, L.; MATEUS, R.; KOUKKARI, H. Building Sustainability Assessment. Sustainability, p. 14, 2010.

BRAGANÇA, L.; MATEUS, R.; KOUKKARI, H. Building Sustainability Assessment. Sustainability, 2010.

BROPHY, V.; LEWIS, J. O. A Green Vitruvius - Principles and Practice os Sustainble Architectural Design. earthscan, v. 2o, p. 153, 2011.

BUENO, C. Avaliação de Ciclo de Vida na Construção Civil. [S.1.]: Universidade de São Paulo, p. 268, 2014.

CASTRO, M. D. F.; MATEUS, R.; BRAGANÇA, L. Práticas Sustentáveis de Projeto em Edifícios Hospitalares, 2012.

CBCS. Conselho Brasileiro de Construção Sustentável, 2015. Disponivel em: $<$ http://www.cbcs.org.br/website/>. Acesso em: maio 2015. 
COMITÉ EUROPEU DE NORMALIZAÇÃO. EN15643-1. Sustainability of Construction Works. Sustainability Assessment of Buildings. Part 1: General Framework, 2010.

COMITÉ EUROPEU DE NORMALIZAÇÃO. EN15643-2. Sustainability of Construction Works - Assessment of Buildings - Part 2: Framework for the Assessment of Environmental Performance, 2011.

COMITÉ EUROPEU DE NORMALIZAÇÃO. EN15643-3. Sustainability of Construction Works e Assessment of Buildings e Part 3: Framework for the Assessment of Social performance, 2012.

COMITÉ EUROPEU DE NORMALIZAÇÃO. EN15643-4. Sustainability of Construction Works e Assessment of Buildings - Part 4: Framework for the Assessment of Economic Performance, 2012.

COMITÉ EUROPEU DE NORMALIZAÇÃO. EN15978. Sustainability of construction works - Assessment of environmental performance of buildings Calculation method, 2011.

CREA-MINAS. Sustentabilidade e Eficiência Energética no Ambiente Construído. p.52, 2009.

DEANE, M. The Builder's Role in Delivering Sustainable Tall Buildings. The Structural Design of Tall and Special Buildings, p. 869-880, 2008.

DIEESE. Estudo Setorial da Construção 2012. Departamento Intersindical de Estatística e Estudos socioeconômicos, p. 42, 2013.

DING, G. K. C. Sustainable construction - the role of environmental assessment tools. Jornal of environmental Management, p. 451-464, 2008.

FABRÍCIO, M. M. Projeto Simultâneo na Construção de Edifícios. Dissertação de Doutorado, São Paulo, 2002.

FABRÍCIO, M. M. O arquiteto e o coordenador de projetos. Pós N.22, São Paulo, 2008.

FABRÍCIO, M. M. Disciplina de Gestão e Coordenação de Projetos de Edifícios IAU5857. Disciplina ministrada no Instituto de Arquitetura e Urbanismo Universidade de São Paulo, 2013.

FERreirA, J. V. R. Análise de Ciclo de Vida dos Produtos. Viseu: Instituto Politécnico de Viseu, 2004.

FERREIRA, J.; PINHEIRO, M. D.; BRITO, J. Portuguese sustainable construction assessment tools benchmarked with BREEAM and LEED: An energy analysis. Energy and Buildings, 2013.

FUNDAÇÃO Vanzolini, 2015. Disponivel em: <http://vanzolini.org.br/conteudoaqua.asp?cod_site $=104 \& i d \_m e n u=760>$. Acesso em: 18 maio 2015.

GARCIA, R. Conferência Rio+20 termina com misto de desalento e de missão cumprida. Público, 22 jun. 2012.

GARCIA, R. Expresso. Cientistas finalizam relatório que reafirma culpa humana no aquecimento global, 22 set. 2013. Disponivel em: $<$ http://www.publico.pt/ecosfera/noticia/cientistas-finalizam-relatorio-que-reafirmaculpa-humana-no-aquecimento-global-1606759>. 
GLOBAL Footprint Network, maio 2015. Disponivel em: $<$ http://www.footprintnetwork.org/en/index.php/GFN/>.

GRUNBERG, P.; MEDEIROS, M.; TAVARES, S. Certificação Ambiental de Habitações: Comparação entre LEED for Homes, Processo AQU e Selo Casa Azul. Ambiente e Sociedade, p. 195-214, 2014.

HAAPIO, A.; VIITANIEMI, P. A critical review of building environmental assessment tools. Environmental Impact Assessment Review, p. 469-482, 2008.

IEA. Technical Synthesis Report - Annex 31. [S.1.]: International Energy Agency, p. 50,2005

ISO 21929. Sustainable in building construcion - Sustainability indicators - par1: Framework for the development of indicators and a core set of indicators for buildings, 2011.

ISO14040, A. N. I. Impacto Ambiental de Bens e Serviços, 2011.

JOHN, V. M.; AGOPYAN, V. Construção Sustentável: mitos, desafios e oportunidades. Desenvolvimento Sustentável 2012-2050 - Visão, rumos e contradições, 2013.

KEELER, M.; BURKE, B. Fundamentos de Projeto de Edifícações Sustentáveis. bookman, p. 362, 2010.

KIBERT, C. J. Sustainable Construction. Green Building Design and Delivery. John Wiley \& Sonsn, Inc., v. 3, 2013. 562 p.

KOHLER, N.; MOFFATT, S. Life-cycle analysis of the built environment. UNEP Industry and Environment, 2003.

KORPI, E.; ALA-RISKU, T. Life Cycle Costing: A Review of Published Case Studies. Managerial Auditing Journal, 2008.

LEED. LEED 2009 for New Construction and Major Renovations; with alternative compliance paths for projects outside the U.S. [S.1.]: U.S. GReen Building Council, p. 108, 2011.

LEED. Leadership in Energy \& Environmental Design. United States Green Building Council, v. 4.0, p. 817, 2013.

LEI n. 12.105. Política Nacional de Resíduos Sólidos, p. 21, 2012. Disponivel em: $<$ http://bd.camara.gov.br/bd/>. Acesso em: maio 2015.

MANENT, C. S. et al. A Design Process Evaluation Method for Sustainable Buildings. Architectural Engineering and Design Management, v. 5, p. 62-74, 2009.

MATEUS, R. Avaliação da Sustentabilidade da Construção. Universidade do Minho: Tese de Doutorado, p. 427, 2009.

MATEUS, R. A Integração do Método LCA na Avaliação e Certificação da Construção Sustentável. Universidade do Minho - Escola de Engenharia, 2011.

MATEUS, R.; BRAGANÇA, L. Sustentabilidade de Soluções Construtivas. Congresso sobre Construção Sustentável, 2006.

MATEUS, R.; BRAGANÇA, L. Tecnologias Construtivas para a Sustentabilidade da Construção. Ecopy, 2006. 
MELhado, S. B. Coordenação de projetos de edificações. São Paulo: O Nome da Rosa, 2005.

MIDÕES, E. N. G. F. A Sustentabilidade e o Ciclo de Vida dos Edifícios. Dissertação de Mestrado. Instituto Superior de Engenharia do Porto, 2012.

MOURÃO, J.; PEDRO, J. B. Princípios de Edificação Sustentável. Lisboa: LNEC, 2012.

NEIVA, S.; MATEUS, R.; BRAGANÇA, L. Utilização do Método LCA no Projeto de Edifícios Sustentáveis. Congresso Construção, 2012.

ONU. Seven Billion and Growing: A 21st Century Perspective on Population, 2012.

ORTIZ, O.; CASTELLS, F.; SONNEMANN, G. Sustainability in the Construction Industry: A Review of Recent Developments Based on LCA. Construction \& Building Materials, 2008.

PBMC. Mitigação das Mudanças Climáticas. Brasília, 2013.

PBQP-H. Programa Brasileiro da Qualidade e Produtividade do Habitat, 2015. Disponivel em: <http://pbqp-h.cidades.gov.br>. Acesso em: maio 2015.

PEREIRA, T. D. Gestão de projeto e contratação de empreitadas de obras. Coimbra: Impresa da Universidade de Coimbra, 2014.

PINHEIRO, M. D. Ambiente e Construção Sustentável. Instituto do Ambiente, 2006.

PMBOK. A Guide to the Project Management Body of Knowledge, 2013.

PMBOK. A Guide to the Project Management Body Of Knowledge (PMBOK) Fifth Edition. Project Managment Institute, 2013.

PNUD. Relatório do Desenvolvimento Humano. Programa das Nações Unidas para o Desenvolvimento, p. 28, 2013.

POCOCK, J. B. et al. Constructability State of Practice Report. Journal of Construction Engineering and Management, 2006.

PWC. World in 2050 - The BRICs and beyond: prospects, challenges and opportunities, 2013.

REIS, D. C. Gestão de Projectos no Âmbito da Construção Sustentável. Dissertação de Mestrado, 2011.

REIS, D. C. Gestão de Projetos no Âmbito da Construção Sustentável. Instituto Superior de Engenharia do Porto, p. 114, 2011.

REKOLA, M.; MÄKELÄINEN, T.; HÄKKINEN, T. The role of design management in the sustainable building process. Architectural Engineering and Design, 2012.

REKOLA, M.; MÄKELÄINEN, T.; HÄKKINEN, T. The role of design management in the sustainable building process. Architectural Engineering and Design Management, p.78-89, 2012.

RYDIN, Y. et al. Sustainable construction and planning : the academic report. England: Centre for Environmental Policy and Governance (CEPG)., p. 34, 2006. 
SANTOS, M. J. N. Desenvolvimento Sustentável e Responsabilidade Empresarial. Celta, 2005.

SILVA, S. M. D. Qualidade do Ambiente Interior de Edifícios. Seminário de Avaliação do Ciclo de Vida na Construção, 2011. 39.

SON, H. et al. Implementing Sustainable Development in the Construction Industry: Constructors' Perspectives in the US and Korea. Sustainable Development, 2009.

TORGAL, F. P.; JALALI, S. A Sustentabilidade dos Materiais de Construção. Guimarães: Tec. Minho, v. I, 2010.

UNEP. Towards a Life Cycle Sustainability Assessment. Life Cycle Initiative, 2012.

WOODWARD, J. F. Construction Project Management. Thomas Telford, 1998.

ZUO, J.; ZHAO, Z.-Y. Green building research - current status and future agenda: A review. Renewable and Sustainable Energy Reviews, 2013. 
ANEXOS 


\section{ANEXO A. CRÉDITOS ASSOCIADOS AO LEED-NC}

Critérios e respetivos pontos associados a cada uma das áreas avaliadas pelo LEEDNC v3.0.

\section{Locais Sustentáveis}

Prevenção da poluição nas atividades de construção

Pré-requisito

Seleção do local

1

Requalificação urbana de áreas com infraestruturas já existentes, protegendo a biodiversidade do local e os seus recursos naturais

Requalificação de locais ambientalmente contaminados por atividades outrora existentes (Brown Field site é a classificação atribuída pela EPA a este tipo de locais)

Transporte Alternativo - Acessos a transportes públicos

Transporte alternativo. Infraestruturas específicas para bicicletas e vestiários para troca de roupa / equipamento

Transporte Alternativo, Estações alternativas para abastecimento de combustíveis $\quad 3$

\begin{tabular}{|l|l} 
Transporte Alternativo. Capacidade do Parque & 2
\end{tabular}

Conservar as áreas naturais existentes e restaurar as áreas danificadas (após 1

construção) para promover a biodiversidade e o habitat natural

Reduzir a pegada ecológica do edifício, promovendo uma maior relação entre a área

de implantação do edifício e os espaços exteriores

Controlo das águas pluviais, através de medidas que promovam a infiltração e

aproveitamento das mesmas. Utilização de sistemas que permitam reduzir e controlar o consumo de água

Implementar um plano de gestão que promova o tratamento e infiltração das águas pluviais, usando as melhores práticas para o efeito

Desenvolver estratégias para reduzir o efeito "ilha de calor" - Superfícies exteriores

Desenvolver estratégias para reduzir o efeito "ilha de calor" - Superfícies cobertas das construções

Desenvolver estratégias para reduzir a poluição luminosa

5

1

6

1

3

2

1

Tabela A1: Locais Sustentáveis v3.0 (LEED, 2011)

\section{Eficiência Hídrica}

Desenvolver estratégias que permitam reduzir o consumo de água da rede pública em $20 \%$ (não incluindo a irrigação)

Pré-requisito

Prever uma redução em $50 \%$ do consumo de água da rede pública destinada a irrigação. Ex.: elevada eficiência do equipamento de irrigação, uso de plantas autóctones, etc.

Desenvolver estratégias que permitam diminuir os efluentes produzidos pelo edifício

Desenvolver estratégias e sistemas que permitam obter uma redução de $30 \%, 35 \%$ ou $40 \%$ no consumo de água potável

Tabela A2: Eficiência Hídrica v3.0 (LEED, 2011) 


\section{Energia e Atmosfera}

Verificação de conformidade dos requisitos (Commissioning) relacionados com a energia estão devidamente implementados tanto na fase de projeto como na construção. Devem ser pessoas qualificadas a liderar este processo

Estabelecer o desempenho energético mínimo, para reduzir os impactos ambientais e econômicos associados ao uso excessivo de energia

Pré-requisito

Zero utilizações de clorofluorcarbonetos (CFC) nos sistemas de aquecimento, ventilação, ar condicionado e sistemas de refrigeração (AVAC\&R)

Desempenho energético otimizado. Para edifícios novos prever reduções entre 12 a $48 \%$; para edifícios existentes na ordem de 8 a $44 \%$

Uso de energia proveniente de fontes renováveis (eólica, solar, geotérmica, biomassa, etc.). A energia deve ser produzida no local

Executar atividades adicionais após a verificação de conformidade dos sistemas instalados. Todas atividades necessárias vêm descriminadas no LEED Reference Guide for Green Building Design and Construction

Projetar os sistemas de AVAC que minimizem o impacto da destruição da camada de ozono

Medição e verificação de desempenho do sistema energético do edifício

Energia Verde (fontes de energia renováveis)

Pré-requisito

$1-19$

$1-7$

2

2

3

Tabela A3: Energia e Atmosfera v3.0 (LEED, 2011)

\section{Materiais e Recursos}

Pontos (14 possíveis)

Prever um local de fácil acesso para armazenamento e recolha de materiais reciclados (papel, vidro, plástico e metais) para a fase de ocupação do edifício

Pré-requisito

Estender o ciclo de vida dos edifícios já existentes, através da reutilização da estrutura existente do edifício, incluindo as paredes, teto e o piso

Estender o ciclo de vida dos edifícios já existentes, através da reutilização de elementos interiores não estruturais do edifício, incluindo paredes interiores, revestimentos de pavimentos e tetos falsos

Gestão dos resíduos de construção e demolição (RCD)

Identificar oportunidades para incorporar materiais e produtos recuperados

Identificar oportunidades para incorporar materiais e produtos reciclados

Identificar oportunidades para incorporar materiais e produtos regionais/locais

Identificar oportunidades para incorporar materiais rapidamente renováveis

Identificar oportunidades para incorporar madeira certificada

Tabela A4: Materiais e Recursos v3.0 (LEED, 2011) 


\section{Qualidade do Ambiente Interior}

Estabelecer o desempenho mínimo para a Qualidade do Ar Interior (QAI) do edifício, contribuindo para o bem-estar dos ocupantes

Evitar ou minimizar a exposição ao fumo do tabaco dos usuários do edifício

Prever a instalação de sistemas que permitam a monotorização do sistema de ventilação, promovendo o conforto dos usuários

Fornecer um aumento da taxa de ventilação para melhorar a QAI

1

Elaborar um plano para gestão da QAI, na fase de construção, com a finalidade de promover a saúde e bem-estar dos trabalhadores e futuros usuários

Elaborar um plano para gestão da QAI, antes da ocupação, com a finalidade de reduzir os problemas relacionados com a QAI, resultantes do processo da construção

Especificar materiais com baixa emissão de Compostos Orgânicos Voláteis (COV's) Adesivos e selantes

Especificar materiais com baixa emissão de COV's - Tintas e vernizes

Especificar materiais com baixa emissão de COV's - Pavimento. Selecionar materiais certificados pelo Green Label Plus

Especificar materiais de baixa composição em resina de ureia-formaldeído, nomeadamente em produtos derivados de madeira e fibras naturais

Desenvolver estratégias para minimizar e controlar a entrada de poluentes para o interior do edifício, sobretudo em zonas regularmente ocupadas

Elaborar estratégias que permitam fornecer um elevado nível de iluminação e controlo do mesmo por parte dos usuários

Elaborar estratégias que permitam assegurar um elevado nível de conforto térmico e controlo dos mesmos por parte dos usuários

Estabelecer critérios de conforto que suportam a qualidade desejada por parte dos ocupantes, no que toca a temperatura do ar, temperatura radiante, velocidade do ar e humidade relativa

Avaliação do conforto térmico dos ocupantes, relativamente aos critérios de conforto térmico estabelecidos pela norma

Projetar o edifício para maximizar a luz natural no interior e vistas para o exterior, para $75 \%$ dos espaços regularmente ocupados

Projetar o edifício para maximizar a luz natural no interior e vistas para o exterior, para $90 \%$ dos espaços regularmente ocupados

\section{Inovação no Projeto}

Oportunidade de alcançar um desempenho excecional, através de medidas mensuráveis de desempenho inovador que não tenham sido especificadas pelo sistema de classificação LEED

Envolvimento de pelo menos um profissional acreditado pelo LEED, tanto na fase de projeto como da construção

Tabela A6: Inovação no Projeto v3.0 (LEED, 2011) 
Critérios e respetivos pontos associados a cada uma das áreas avaliadas pelo LEED-

$\mathrm{NC}$ v.4.0

\section{Localização e Transporte}

Pontos $(16$ possíveis)

Proteção de locais ambientalmente sensíveis

1

Construir ou reabilitar/recuperar um edifício em áreas com condicionantes locais (tais como centros históricos, locais ambientalmente contaminados)

Construir ou reabilitar/recuperar um edifício em áreas previamente desenvolvidas e próximo de amenidades

Acesso a transportes multimodais próximo da localização do edifício

Infraestruturas e comodidades necessárias para promover o uso de bicicletas por parte dos usuários do edifício

Reduzir a pegada ecológica do parque de estacionamento para minimizar os danos ambientais associados às dependências do automóvel

Promover infraestruturas para promover a utilização de veículos verdes (por exemplo elétricos)

Tabela A7: Localização e Transporte v4.0 (LEED, 2013)

2

5

5

1

\section{Locais Sustentáveis}

Pontos $(10$ possíveis)

Prevenção da poluição nas atividades de construção

Pré-requisito

Avaliação do local

1

Conservar as áreas naturais existentes e restaurar as áreas danificadas (após construção) para promover a biodiversidade e o habitat natural

2

Reduzir a pegada ecológica do edifício, promovendo uma maior relação entre a área de implantação do edifício e os espaços exteriores

Implementar um plano de gestão das águas pluviais, promovendo a qualidade da mesma com base nas condições históricas e ecossistemas do local

1

Desenvolver estratégias para reduzir o efeito "ilha de calor nas superfícies cobertas das construções e superfícies exteriores

Desenvolver estratégias para reduzir a poluição luminosa

Tabela A8: Locais Sustentáveis v4.0 (LEED, 2013) 


\section{Eficiência Hídrica}

Reduzir o consumo de água exterior em $30 \%$ do consumo de água em relação à baseline, ao nível da irrigação

Pré-requisito

Reduzir o consumo de água interior em $20 \%$ do consumo de água em relação à

baseline, ao nível dos sistemas e equipamentos (sanitários, ducha, etc.)

Instalar medidores de água permanentes de água potável ao nível do edifício

Pré-requisito

Prever uma redução de pelo menos $50 \%$ do consumo de água destinada a irrigação.

Ex.: elevada eficiência do equipamento de irrigação, uso de plantas autóctones, etc.

Prever uma redução de pelo menos $25 \%$ do consumo de água em relação à baseline,

ao nível dos sistemas e equipamentos (sanitários, ducha, etc.)

Desenvolver estratégias que permita economizar água ao nível da torre de

refrigeração

Instalar medidores de água permanentes em pelo menos dois subsistemas

Pré-requisito

Tabela A9: Eficiência Hídrica v4.0 (LEED, 2013)

\section{Energia e Atmosfera}

Verificação de conformidade dos requisitos (Commissioning) relacionados com a energia estão devidamente implementados tanto na fase de projeto como na construção, ao nível da energia, água, qualidade do ar interior e durabilidade

Estabelecer o desempenho energético mínimo, para reduzir os impactos ambientais e econômicos associados ao uso excessivo de energia

Pré-requisito

Medição de energia ao nível do edifício

Pré-requisito

Zero utilizações de clorofluorcarbonetos (CFC) nos sistemas de aquecimento, ventilação, ar condicionado e sistemas de refrigeração (AVAC\&R)

$1-2$

$1-6$

1

Executar atividades adicionais após a verificação de conformidade (Commissioning) dos sistemas instalados. Todas atividades necessárias devem avaliar as exigências de desempenho do projeto ao nível de energia, água, qualidade do ar interior e durabilidade

Desempenho energético otimizado. Para edifícios novos prever reduções entre 12 a $48 \%$; para edifícios existentes na ordem de 8 a $44 \%$

Medição de energia avançada, através da monitorização ao nível da instalação e utilização dos sistemas

Utilização de sistemas tecnológicos que tornem os sistemas de geração e distribuição de energia mais eficientes

Uso de energia proveniente de fontes renováveis (eólica, solar, geotérmica, biomassa, etc.). A energia deve ser produzida no local

Projetar os sistemas de AVAC que minimizem o impacto da destruição da camada de ozono

Energia Verde (fontes de energia renováveis) e minimização de carbono

Tabela A10: Energia e Atmosfera v4.0 (LEED, 2013) 


\section{Materiais e Recursos}

Prever um local de fácil acesso para armazenamento e recolha de materiais reciclados (papel, vidro, plástico e metais) para a fase de ocupação do edifício

Plano de Gestão dos Resíduos de Construção e Demolição (RCD), permitindo reduzir o volume de resíduos destinados a aterros

Aumentar o ciclo de vida dos materiais e sistemas construtivos já existentes, através da reutilização da estrutura existente, de pavimentos, tetos falsos, paredes, entre outros

Declarações ambientais de produtos. Promover produtos e materiais de construção para os quais existem informações de ciclo de vida disponíveis e selecionar os produtos que apresentam menores impactos ambientais

Identificar matérias primas tenham disponíveis informações de ciclo de vida. Selecionar aqueles que apresentem baixos impactos de ciclo de vida ambiental, económico e social.

Identificar produtos e materiais que tenham disponíveis informações de ciclo de vida. Selecionar aqueles que apresentem baixos impactos de ciclo de vida ambiental, económico e social.

Reduzir em pelo $50 \%$ os RCD destinados a aterro e inceneração, através da reciclagem e reaproveitamento dos mesmos

Tabela A11: Materiais e Recursos v4.0 (LEED, 2013)

\section{Qualidade do Ambiente Interior}

Estabelecer o desempenho mínimo para a Qualidade do Ar Interior (QAI) do edifício, contribuindo para o bem-estar dos ocupantes

Evitar ou minimizar a exposição ao fumo do tabaco dos usuários do edifício

Pré-requisito

Estabelecer estratégias que permitam melhorar a QAI, promovendo o conforto, bem-estar e produtividade dos usuários

Especificar materiais com baixa emissão de Compostos Orgânicos Voláteis (COV's)

Elaborar um plano para gestão da QAI, na fase de construção e pré-ocupação do edifício

Avaliação da QAI após construção e durante a fase de ocupação

2

Elaborar estratégias que permitam assegurar um elevado nível de conforto térmico e controlo dos mesmos por parte dos usuários

Adequada iluminação interior

2

Projetar o edifício para maximizar a luz natural no interior

Projetar o edifício para maximizar as vistas para o exterior

Desempenho acústico adequado

Pré-requisito

$1-3$

1

1

3

1

Tabela A12: Qualidade do Ambiente Interior v4.0 (LEED, 2013) 
Oportunidade de alcançar um desempenho excecional, através de medidas mensuráveis de desempenho inovador que não tenham sido especificadas pelo sistema de classificação possíveis)

LEED

Envolvimento de pelo menos um profissional acreditado pelo LEED, tanto na fase de projeto como da construção

Tabela A13: Inovação no Projeto v4.0 (LEED, 2013) 


\section{ANEXO B. EXPOSIÇÃO DA FERRAMENTA}

Considerando o tamanho e extensão da ferramenta que se propõe expor no presente anexo, opta-se por veicular a mesma através da seguinte hiperligação: http://www.iau.usp.br/pesquisa/grupos/arquitec/dreis/ProSus.xlsx

O arquivo tem o nome de ProSus (Projeto Sustentável) e encontra-se em formato xls (Excel). 